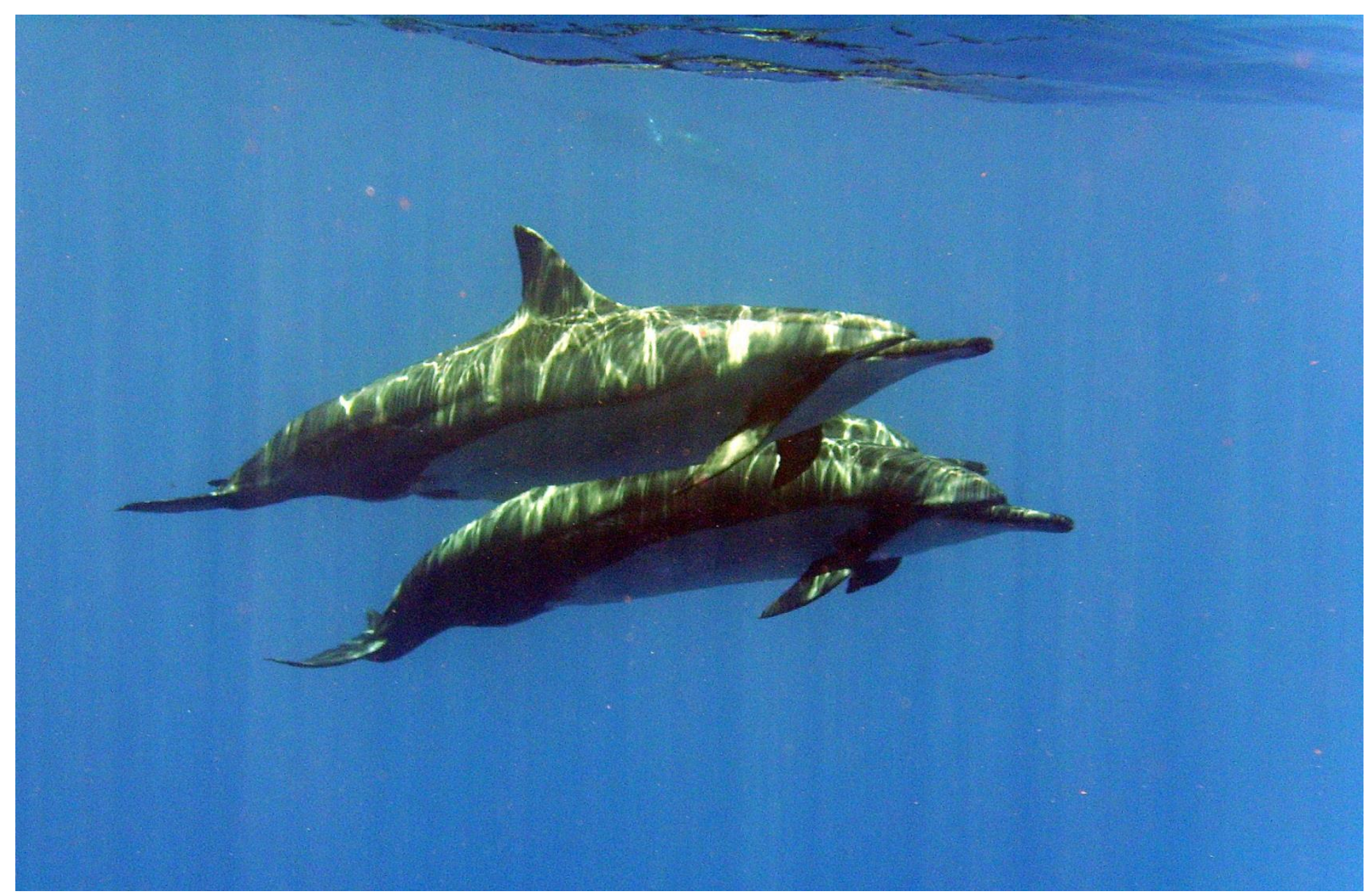

\title{
Priorities in management implementation for marine mammal conservation in the Saba sector of the Yarari sanctuary
}




\section{Priorities in management implementation for marine mammal conservation in the Saba sector of the Yarari sanctuary}

Author(s): $\quad$ A.O. Debrot, J.E. Tamis, D. de Haan, M. Scheidat, J.T. van der Wal

Publication date: $30^{\text {th }}$ November 2017

This research project was carried out by Wageningen Marine Research at the request of and with funding from the Ministry of Economic Affairs for the purposes of Policy Support Research Theme

'Caribbean Netherlands' (project no. BO-11-019.02-054).

Wageningen Marine Research

Den Helder, November 2017

Wageningen Marine Research report C097/17 
A.O. Debrot, J.E.Tamis, D. de Haan, M. Scheidat, J.T. van der Wal, 2017. Priorities in management implementation for marine mammal conservation in the Saba sector of the Yarari sanctuary. Wageningen, Wageningen Marine Research (University \& Research centre), Wageningen Marine Research report C097/17. 103 pp.

Keywords: Yarari, Caribbean, marine mammal, sanctuary, management, priorities.

Client: Ministry of LNV (Agriculture, Nature and Food Quality)

Attn.:

Paul C. Hoetjes, Policy Coordinator Nature

P.O. Box 20401,

2500 EK The Hague,

The Netherlands

BO-11-019.02-054

This report can be downloaded for free from https://doi.org/10.18174/428169

Wageningen Marine Research provides no printed copies of reports.

Wageningen Marine Research is ISO 9001:2008 certified.

Photo cover: Dr. Mark Vermeij

(C) 2016 Wageningen Marine Research Wageningen UR

Wageningen Marine Research The Management of Wageningen Marine Research is not responsible for resulting institute of Stichting Wageningen damage, as well as for damage resulting from the application of results or Research is registered in the Dutch research obtained by Wageningen Marine Research, its clients or any claims traderecord nr. 09098104, BTW nr. NL 806511618 related to the application of information found within its research. This report has been made on the request of the client and is wholly the client's property. This report may not be reproduced and/or published partially or in its entirety without the express written consent of the client. 


\section{Contents}

Summary

Abbreviations and Acronyms

1 Introduction

2 Species distribution and human activities in the area

$\begin{array}{lll}2.1 & \text { Overview of relevant marine mammal species } & 10\end{array}$

$\begin{array}{lll}2.2 & \text { Distribution and abundance in the area } & 13\end{array}$

2.2.1 Species known to occur in the windward Dutch Caribbean 13

$\begin{array}{ll}2.2 .2 & \text { Regional comparison of distribution } \\ 2.2 .3 & 19\end{array}$

$\begin{array}{lll}2.2 .3 & \text { Temporal distribution } & 23\end{array}$

$\begin{array}{lll}2.3 & \text { Potential impact of human activities } & 24\end{array}$

$\begin{array}{lll}2.3 .1 & \text { Fishery } & 24\end{array}$

2.3.2 Noise pollution $\quad 30$

2.3.3 Marine debris $\quad 35$

2.3.4 Contaminants 36

2.3.5 Habitat degradation / physical barriers 38

2.3.6 Whale \& dolphin watching 38

2.3.7 Climate change 38

$\begin{array}{lll}2.3 .8 & \text { Cumulative effects } & 39\end{array}$

$\begin{array}{lll}2.4 & \text { Knowledge gaps } & 40\end{array}$

2.5 Summary assessment of threats $\quad 42$

2.5.1 Analysis of current and future potential threats $\quad 42$

$\begin{array}{lll}\text { 2.5.2 } & \text { Recommendations on threats to address } & 43\end{array}$

2.5.3 Recommendations on key research and monitoring 43

$3 \quad$ Management insights from marine mammal sister sanctuaries $\quad 44$

$\begin{array}{lll}3.1 & \text { Introduction } & 44\end{array}$

3.2 Sanctuaries $\quad 46$

3.2.1 AGOA Sanctuary $\quad 46$

3.2.2 Stellwagen Bank National Marine Sanctuary 49

3.2.3 Bermuda $\quad 54$

3.2.4 Dominican Republic $\quad 57$

$\begin{array}{lll}3.3 & \text { Summary and conclusions } & 59\end{array}$

$4 \quad$ Key opportunities for regional cooperation on marine mammals 62

$\begin{array}{lll}4.1 & \text { Introduction } & 62\end{array}$

$\begin{array}{lll}4.2 & \text { Regional initiatives } & 62\end{array}$

4.2.1 Specially Protected Areas and Wildife (SPAW) Protocol 62

4.2.2 The Wider Caribbean Region Marine Mammal Action Plan 62

4.2.3 The Sister Sanctuary Program 63

4.2.4 Regional efforts directed towards protection of marine mammals in the Wider $\begin{array}{ll}\text { Caribbean } & 64\end{array}$

$\begin{array}{lll}4.3 & \text { Summary and conclusions } & 66\end{array}$

$5 \quad$ Structuring and prioritizing marine mammal goals and objectives: an expert consultation

5.1 Introduction 
$\begin{array}{lll}5.2 & \text { Survey of expert opinion } & 67\end{array}$

$\begin{array}{lll}5.3 & \text { Results } & 67\end{array}$

$\begin{array}{lll}5.4 & \text { General conclusions on priority goals and objectives } & 74\end{array}$

6 An effective sanctuary governance and management structure model $\quad 75$

$\begin{array}{lll}6.1 & \text { Introduction } & 75\end{array}$

$\begin{array}{lll}6.2 & \text { Saba Bank Management Unit (SBMU) } & 75\end{array}$

$\begin{array}{ll}6.3 \text { Conclusions } & 77\end{array}$

$\begin{array}{lll}6.3 .1 & \text { Governance } & 77\end{array}$

$\begin{array}{ll}\text { 6.3.2 Logistics: } & 77\end{array}$

7 Synopsis of key priorities and action points towards implementation of sanctuary $\begin{array}{ll}\text { management for marine mammals } & 78\end{array}$

$\begin{array}{llr}7.1 & \text { Governance } & 78\end{array}$

$\begin{array}{lll}7.2 & \text { Legal resources } & 78\end{array}$

$\begin{array}{lll}7.3 & \text { Finances } & 78\end{array}$

$\begin{array}{lll}7.4 & \text { Personnel and logistics } & 78\end{array}$

$\begin{array}{lll}7.5 & \text { Management priorities } & 79\end{array}$

$\begin{array}{lll}7.6 & \text { Research priorities } & 79\end{array}$

$8 \quad$ Quality Assurance $\quad 80$

$\begin{array}{lr}\text { References } & \mathbf{8 2}\end{array}$

$\begin{array}{lr}\text { Justification } & 91\end{array}$

Annex 1 I UCN Red List status of marine mammals occurring in the WCR 92

$\begin{array}{lr}\text { Annex } 2 \text { Cetacean guide } & 94\end{array}$

$\begin{array}{lr}\text { Annex } 3 \text { Questionnaire } & 100\end{array}$ 


\section{Summary}

The Yarari Marine Mammal Sanctuary (hereafter simply referred to as the Yarari Sanctuary, or Yarari) was formally established on September 2, 2015. It is currently composed of two sectors: one surrounding Saba and the Saba Bank and one covering the EEZ waters of Bonaire. In order to help establish an effective cetacean conservation management plan for the Saba and Saba Bank sector of the sanctuary we here review the main marine mammal threats, help identify main management goals and make both governance and management recommendations based both on stakeholder interviews and a management review of functioning marine mammal sanctuaries in the Western Atlantic.

There are 8 species of marine mammals known to occur in the windward Dutch Caribbean Yarari Sanctuary. The sanctuary has relatively low levels of human activity. Based on our review, cumulative contaminant impacts - such as oil contamination originating from St. Eustatius - are potentially highest, followed by collision impacts due to the relatively high level of shipping traffic. Other factors such as, fishery entanglement, bycatch-impacts and marine debris impacts are likely low compared to many areas directly outside the sanctuary. While whale $\&$ dolphin watching impacts are still probably negligible, the impacts of anthropogenic noise, climate-change impacts and cumulative impacts still remain unknown but are potentially high.

Five main clusters of interrelated goals and objectives were identified based on expert and management stakeholder interviews. The most essential proximate goal for management should be to establish a minimum structural level of institutional capacity. Under the reigning conditions of resource limitation, the next key goal should be to establish effective collaboration towards jointly achieving the higher management goals and objectives.

Based on our review of species, threats, operations of other sanctuaries and expert and stakeholder input we list 23 priority recommendations and action points towards implementation of cetacean conservation for the Saba and Saba Bank Yarari sector.

\section{Governance}

- Use the Saba Bank Management Unit (SMBU) governance model for Yarari management implementation.

- Consider merging Yarari tasks into the SMBU to effectuate resource pooling and prevent management fragmentation.

Legal resources

- Design and implement a simple legal mandate for Yarari management.

- Copy and implement international legal guidelines for whale watching.

- Revise the Fishery Framework Act BES (Vissery Visserijwet besluit BES) or draft a Decree (Regeling) under the Nature Conservation Framework Act BES (Wet Grondslagen Natuurbeheer en-bescherming, WGN) to forbid all forms of pelagic (not benthic) longline and purse seine fishing in Yarari waters.

- Devise and implement legal measures and guidelines to safeguard Yarari from anthropogenic noise pollution.

\section{Finances}

- Based on the review of functioning sanctuaries, and current stressor levels, a basic annual budget of US\$150 K will be sufficient to implement satisfactory marine mammal conservation.

- Focus expenditures on management development, outreach and international cooperation.

- Limit expenditures on costly enforcement and research. Participation in these activities should principally be limited to essential monitoring and practical support of collaborating parties. 
Personnel and logistics

- Based on the review of functioning sanctuaries, two (additional) personnel members are sufficient to effectuate adequate Yarari cetacean conservation.

- The combined personnel should include both technical and boat handling skills as well as management development skills for effective local and international policy development support and cooperation.

- Saba island is the logical choice for basing Yarari headquarters.

- A larger vessel (than the current Queen Beatrix) is needed for safer and more effective operation in Yarari waters.

Management priorities

- $\quad$ Aim for sanctuary expansion to include St. Maarten and St. Eustatius marine waters (and ultimately also Curaçao and Aruba EEZ waters).

- Establish and expand cooperation with local enforcement and research partners.

- Develop close ties with local stakeholders and encourage their active involvement.

- Actively represent Yarari interests in regional marine mammal policy development and research initiatives.

Research priorities

- Use remote methods (AIS) and current port fishery sampling to monitor fishery activity, and ship traffic inside Yarari.

- Use passive acoustic monitoring and sighting records to monitor cetacean distribution and abundance.

- Use passive acoustic monitoring to measure and follow background noise levels.

- Record and collect data on and specimens from stranding incidents using published guidelines and protocols.

- Subsample stranding fatalities to determine contaminant loads of the cetaceans inside Yarari and their prey species.

- Document the abundance and source of marine debris found in the sanctuary. 


\title{
Abbreviations and Acronyms
}

\author{
$A B C$ islands \\ Aruba, Bonaire and Curaçao \\ ASFMC \\ Atlantic States Marine Fisheries Commission (a commission of U.S. states formed to \\ coordinate and manage fishery resources) \\ CBD \\ CECS \\ CITES \\ CMS \\ DCCG \\ DENR \\ DPS \\ EEZ \\ FAD \\ FMP \\ GIS \\ ICCAT \\ Convention of Biological Diversity (a global agreement addressing all aspects of \\ biological diversity) \\ Chemicals of Emerging Concern \\ Convention on International Trade in Endangered Species of Wild Fauna and Flora (an \\ international agreement between governments, aiming to ensure that international \\ trade in specimens of wild animals and plants does not threaten their survival) \\ Convention on the Conservation of Migratory Species of Wild Animals (environmental \\ treaty under the aegis of the United Nations Environment Programme) \\ Dutch Caribbean Coast Guard \\ Department of Environment and Natural Resources (Bermuda) \\ Distinct Population Segments \\ Exclusive Economic Zone \\ Fish Aggregating Device \\ Fishery Management Plan \\ Geographic Information Systems \\ International Commission for the Conservation of Atlantic Tunas (an inter- \\ governmental fishery organization responsible for the conservation of tunas and tuna- \\ like species in the Atlantic Ocean and its adjacent seas) \\ ICRW International Convention for the Regulation of Whaling (convention responsible for \\ establishing the International Whaling Commission - IWC) \\ I MO International Maritime Organisation (agency of the United Nations responsible for \\ improving maritime safety and preventing pollution from ships) \\ IUCN International Union for Conservation of Nature (the global authority on the status of \\ the natural world and the measures needed to safeguard it) \\ IWC International Whaling Commission (an intergovernmental organisation whose purpose \\ is the conservation of whales and the management of whaling) \\ MAFMC Mid-Atlantic Fishery Management Council (one of eight fishery management councils \\ responsible for the management of marine fisheries in the U.S.) \\ MARU \\ Ministry EZ \\ Ministry I\&M \\ MMAP \\ MMBD \\ Marine Autonomous Recording Unit (unit for collecting passive acoustic data) \\ Ministry of Economic Affairs (the Netherlands) \\ Ministry of I nfrastructure and the Environment (the Netherlands) \\ Wider Caribbean Region Marine Mammal Action Plan (published by the UNEP) \\ Marine Mammal Behavioral Disturbance (one of three action plans established \\ regarding marine mammal protection in the Stellwagen Sanctuary) \\ MME \\ Marine Mammal Entanglement (one of three action plans established regarding \\ marine mammal protection in the Stellwagen Sanctuary) \\ MMVS Marine Mammal Vessel Strike (one of three action plans established regarding marine \\ mammal protection in the Stellwagen Sanctuary) \\ NEFMC New England Fishery Management Council (one of eight fishery management councils \\ responsible for the management of marine fisheries in the U.S.) \\ NGO Non-Governmental Organization (a not-for-profit organization that is independent \\ from states and international governmental organizations) \\ NOAA National Oceanic and Atmospheric Administration (U.S.) \\ ONMS Office of National Marine Sanctuaries (U.S.) \\ PAHS \\ PCBS \\ Polycyclic aromatic hydrocarbons \\ Polychlorinated Biphenyls \\ PSSA \\ Particularly Sensitive Sea Area \\ RCN \\ National Office for the Caribbean Netherlands
}


Specially Protected Areas and Wildlife (the SPAW Protocol (in-force 2000) is part of the Convention for the Protection and Development of the Marine Environment of the Wider Caribbean Region (Cartagena Convention, in-force 1986))

SPAW-RAC SPAW Regional Activity Centre (aimed at implementing the protocol concerning specially protected areas and wildlife in the Caribbean region)

UNEP United Nations Environment Programme

WCR Wider Caribbean Region

WGoMCA Western Gulf of Maine Closed Area (U.S.)

WWF World Wildlife Fund (organization in wildlife conservation and endangered species) 


\section{$1 \quad$ Introduction}

Marine mammals are protected worldwide by several international treaties among which ICRW, CBD, SPAW, CMS and CITES. The Caribbean parts of the Kingdom of the Netherlands, which consist of the combined territories of the Caribbean Netherlands and those of Aruba, Curaçao and St. Maarten, possess a diverse and rich marine mammal fauna. In recognition of this, the Kingdom designated large parts of these waters as the new Yarari Marine Mammal and Shark Sanctuary to offer new habitat protection to both these endangered groups.

In preparation towards this major development Wageningen Marine Research conducted supporting research into the use of acoustics for the study of marine mammals, sought cooperation with regional partners, led the drafting of a joint research approach and conducted various smaller supporting research projects and trials.

The Yarari Marine Mammal and Shark Sanctuary (hereafter simply referred to as the Yarari Sanctuary, or Yarari) was formally established on September 2, 2015. It is currently composed of two sectors: one surrounding Saba and the Saba Bank and one covering the EEZ waters of Bonaire. In order to establish an effective management plan for the sanctuary we here discuss the steps and measures needed for marine mammal conservation in this new sanctuary. Shark conservation falls outside the scope of this report. As the Ministry of LNV considered management implementation for the Saba and Saba Bank Yarari sector (where the Saba Bank Management Unit already represents actual management capacity) as a first priority, our assignment here was limited to the Saba and Saba Bank Yarari sector. This report addresses the following matters:

- Distribution and abundance of marine mammal species in and around the sanctuary

- An assessment of threats to these species potentially occurring in and around the sanctuary

- Management priorities of sister sanctuaries

- $\quad$ Suggested management priorities for the sanctuary

- Institutional constraints and needs for marine mammal conservation in the sanctuary 


\section{Species distribution and human activities in the area}

\subsection{Overview of relevant marine mammal species}

The Yarari Marine Mammal and Shark Sanctuary consists of two areas, corresponding to the two sectors of the Dutch Caribbean EEZ: the southern sector associated with the leeward ABC islands (Aruba, Bonaire and Curaçao) lying off the coast of Venezuela, and the northern sector, associated with the windward islands of Saba, St Eustatius and St Maarten. This section describes the relevant marine mammal species occurring in the northern sector of the Yarari Sanctuary (Figure 1) situated around Saba and the Saba Bank. The EEZ areas of the Dutch Caribbean fall principally in the pelagic zone referred to as the Venezuela Basin. Relatively little is known about the deep slope and seafloor waters of the Dutch Caribbean EEZ (van Beek 2016).

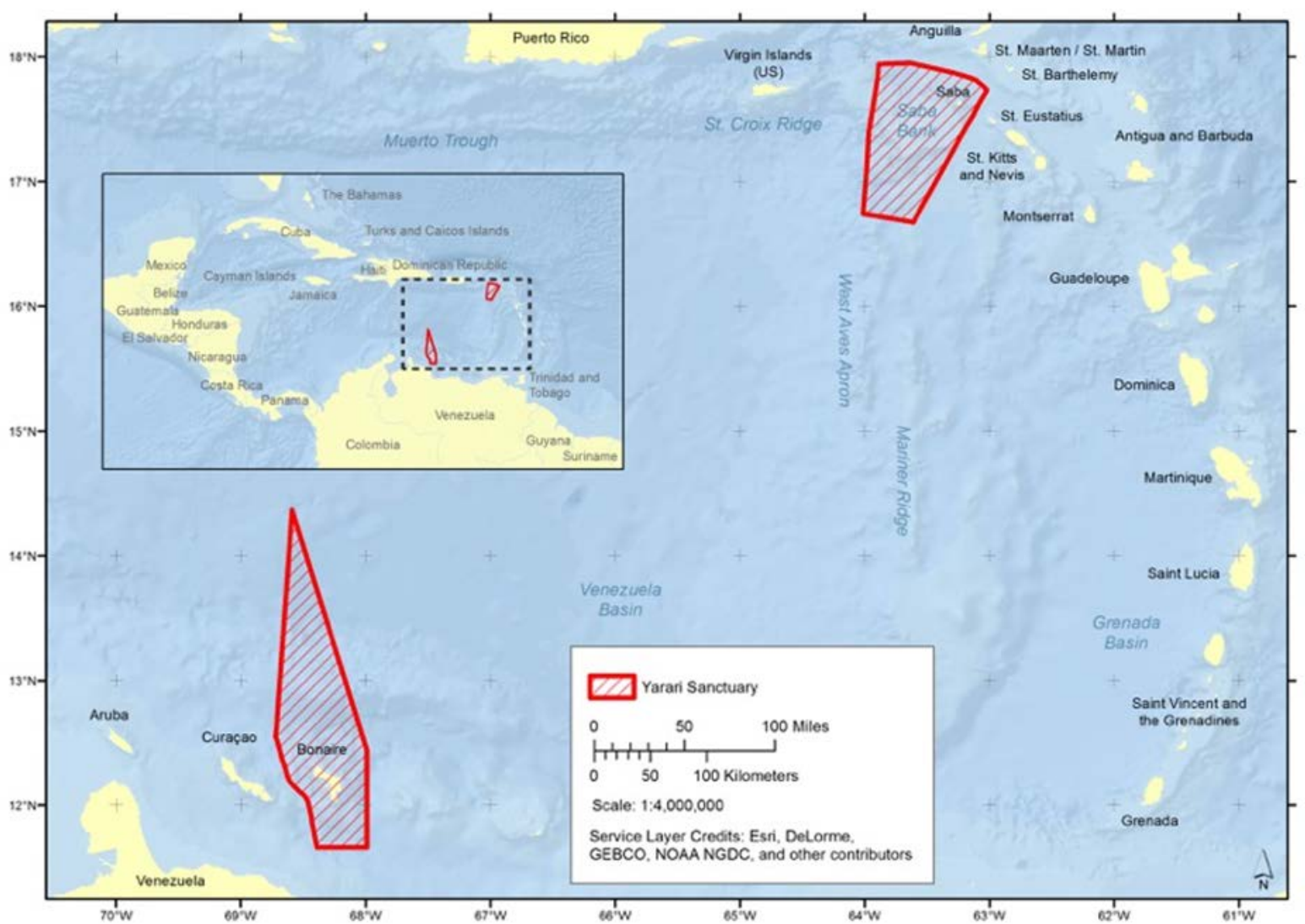

Figure 1 Map of the Yarari Sanctuary, at the leeward Dutch Caribbean in the south and the windward Dutch Caribbean in the north. This study primarily focusses on the windward Dutch Caribbean, i.e. northern part of Yarari.

Knowledge on the density, distribution and habitat use of marine mammal species in the Yarari Sanctuary is essential for adequate conservation measures to be taken and their effectiveness to be monitored. In the vicinity of the windward Dutch Caribbean a number of dedicated surveys have taken place (Table 1). However, most of the information currently available on cetacean occurrence in the Caribbean Netherlands is based on the collation of opportunistic sightings and strandings data (Scheidat et al., 2015). Also, some information is available for the leeward Dutch Caribbean (e.g. Geelhoed et al., 2014; Barros and Debrot, 2006), but this falls outside the scope of this study. 
Table 1 Overview of information currently available (since the 90's) on cetacean occurrence in the northern sector of the Caribbean Netherlands

\begin{tabular}{|c|c|c|c|}
\hline Type & Area & Period & Reference \\
\hline Dedicated survey & French waters & 2008 & Ridoux et al. (2010) \\
\hline Summary description & Dutch Caribbean EEZ & $1966-2010$ & Debrot et al. (2011a) \\
\hline Synoptic overview & Dutch Caribbean EEZ & Up to 2010 & Debrot et al. (2011b) \\
\hline Dedicated survey & St Maarten & 2011 & $\begin{array}{l}\text { Nature Foundation St Maarten } \\
\text { (2011) }\end{array}$ \\
\hline Dedicated survey & Saba bank & 2011 & Geelhoed \& Verdaat (2012) \\
\hline Opportunistic data, review & $\begin{array}{l}\text { Northeastern Caribbean Windward Dutch } \\
\text { Islands: Saba, St Eustatius, St Maarten, } \\
\text { and the Saba Bank }\end{array}$ & $1966-2010$ & Debrot et al. (2013a) \\
\hline Opportunistic data* & Saba, St Eustatius and Bonaire & 2012-2014 & Scheidat et al. (2015) \\
\hline
\end{tabular}

* Based on fishermen interviews, sightings of whales or dolphins during 1020 days at sea monitored from Saba (2012-2014) and 116 days at sea monitored from Bonaire (2014) were reported and analysed

Debrot et al. (2013a) showed that marine mammals, particularly the humpback whale, make notably regular and consistent use of the windward Dutch EEZ. Debrot et al. (2013a) cites several studies where at least 33 native species of marine mammals have been documented from the Wider Caribbean Region (WCR): namely six species of baleen whales, 24 species of toothed whales, one sirenian (the West Indian manatee), and two pinnipeds (the extinct Caribbean monk seal, and the vagrant hooded seal). For many of these species, the waters of the region serve as primary habitat for critical activities that include feeding, mating and calving. However, relatively little remains known about their biology, life history, distribution and behaviour, particularly also around the windward Dutch islands (Saba, St Eustatius and St Maarten) (Debrot et al., 2013a).

In 2010 it was reported that of these species, at least 16 have been documented for the waters of the Netherlands Antilles (Meesters et al., 2010). In 2011 this number had increased to 19 confirmed species in total (Debrot et al., 2011a), see Table 2. In comparison to the leeward Dutch islands (Aruba, Curaçao and Bonaire), documented cetacean strandings are few in the windward islands (St Maarten, Saba and St Eustatius) (Debrot et al., 2011a). There are nine confirmed species in the windward islands, which will be described in section 2.2. The leeward Dutch islands have the most confirmed species of the Dutch Caribbean. The islands with most species confirmed are Curaçao and Aruba (15 species). Scheidat et al. (2015) reported sightings by fishermen: a total of 36 whale sightings ( 62 animals) were recorded in Saba and 4 ( 4 animals) in Bonaire. Most of the whale sightings were not identified to species level. Only at Saba, 10 of the 36 sightings were identified as humpback whales and 1 as sperm whale. There were 71 dolphin sightings (877 animals) from Saba and 19 sightings (341 animals) from Bonaire.

Seals do not commonly occur in the Dutch Caribbean. Naturally-occurring hooded seals (Cystophora cristata) have been confirmed for nearby US waters by several authors as described by Debrot et al. (2013a). Historical records indicate that the southern Caribbean was part of the normal range of distribution of the extinct West Indian monk seal (Monachus tropicalis), although such records were not found in the windward Dutch islands (Debrot 2000). 
Table 2 Overview of marine mammal occurrences in the windward and leeward Dutch Caribbean (Debrot et al. 2011a)

\section{Windward Dutch Caribbean Leeward Dutch Caribbean}

\section{Odontocetes (Toothed whales)}

Bottlenose dolphin\#

Spinner dolphin*\#

Clymene dolphin

Rough-toothed dolphin

Pantropical spotted dolphin*

Atlantic spotted dolphin

Striped dolphin*

Long-beaked common dolphin

Risso's dolphin

Fraser dolphin

Melon-headed whale

Short-finned pilot whale\#

Pygmy sperm whale

False killer whale

Pygmy killer whale

Killer whale\#

Cuvier's beaked whale*

Blainville's beaked whale

Gervais' beaked whale* \#

Dwarf sperm whale*

Sperm whale*

Balaenoptera (Baleen whales)

Blue whale

Fin whale

Sei whale

Common minke whale $\delta$

Bryde's whale*\#

Humpback whale* \#

Manatees

West Indian manatee

Seals

Caribbean monk seal

Unid. seal

Tursiops truncatus
Stenella longirostris
Stenella clymene
Steno bredanensis
Stenella attenuata
Stenella frontalis
Stenella coeruleoalba
Delphinus capensis
Grampus griseus
Lagenodelphis hosei
Peponocephala electra
Globicephala
macrorhynchus
Kogia breviceps
Pseudorca crassidens
Feresa attenuata
Orcinus orca
Ziphius cavirostris
Mesoplodon densirostris
Mesoplodon europaeus
Kogia simus
Physeter macrocephalus

\begin{tabular}{|c|c|}
\hline V & V \\
\hline$?$ & V \\
\hline$?$ & $?$ \\
\hline$?$ & $?$ \\
\hline$?$ & $?$ \\
\hline$?$ & V \\
\hline$?$ & $?$ \\
\hline$?$ & $?$ \\
\hline$?$ & $?$ \\
\hline$?$ & $?$ \\
\hline$?$ & $?$ \\
\hline V & V \\
\hline$?$ & $?$ \\
\hline$?$ & $?$ \\
\hline$?$ & $?$ \\
\hline$?$ & $?$ \\
\hline$?$ & $\mathrm{~S}$ \\
\hline$?$ & $?$ \\
\hline$?$ & $?$ \\
\hline$?$ & $?$ \\
\hline B & B \\
\hline
\end{tabular}

Balaenoptera musculus

Balaenoptera physalus

Balaenoptera borealis

Balaenoptera acutorostrata ?

Balaenoptera edeni

Megaptera novaeangliae

Trichechus manatus

$? \quad V$

Monachus tropicalis

Pinniped sp.

\begin{tabular}{|c|c|c|}
\hline V & V & V \\
\hline V & V & V \\
\hline$?$ & $?$ & $?$ \\
\hline$?$ & V & $?$ \\
\hline$?$ & V & V \\
\hline$?$ & B & $?$ \\
\hline$?$ & $\mathrm{~S}$ & $?$ \\
\hline$?$ & $?$ & $?$ \\
\hline$?$ & $\mathrm{~S}$ & $?$ \\
\hline$?$ & $?$ & $\mathrm{~S}$ \\
\hline$?$ & $?$ & B \\
\hline$?$ & $\mathrm{~S}$ & V \\
\hline$?$ & $?$ & $?$ \\
\hline$?$ & V & $?$ \\
\hline$?$ & $?$ & $?$ \\
\hline$?$ & V & $\mathrm{V}$ \\
\hline$?$ & $\mathrm{~S}$ & $\mathrm{~S}$ \\
\hline$?$ & $?$ & $?$ \\
\hline$?$ & $S$ & $\mathrm{~S}$ \\
\hline$?$ & $\mathrm{~S}$ & $?$ \\
\hline V & $\mathrm{S}$ & $?$ \\
\hline
\end{tabular}

Total native, extant

4

9

4

$15 \quad 11$

$?=$ possible occurring no sightings confirmed; - = not occurring (as far as known); $\mathrm{S}=$ stranded or found dead; $\mathrm{V}=(\mathrm{visual})$ sighted alive; $\mathrm{B}=$ both (stranded and sighted alive); $\dagger=$ extinct; * documented from the area before 1998; \# recorded by Debrot (1998); $\delta$ acoustic detection by Risch et al. (2014). 


\subsection{Distribution and abundance in the area}

\subsubsection{Species known to occur in the windward Dutch Caribbean}

In this section the occurrence of species with confirmed sightings in the Dutch Caribbean are described. There are no species with confirmed sightings for only the windward islands (Saba, St Maarten and St Eustatius), which is the focus of this study. There are 8 species known to occur in both the leeward as in the windward Dutch Caribbean: bottlenose dolphin; spinner dolphin; Atlantic spotted dolphin; short-finned pilot whale; humpback whale; sperm whale; Cuvier's beaked whale; and the west Indian manatee (Table 2). There are no confirmed sightings of minke whale but it is probably quite common for the windward islands, based on confirmed acoustic detections (Risch et al., 2014; Risch and de Haan 2016). Most species (11), however, are so far only confirmed to occur near the leeward islands (Aruba, Bonaire, Curaçao): rough-toothed dolphin; pantropical spotted dolphin; striped dolphin; Risso's dolphin; Fraser dolphin; melon-headed whale; Bryde's whale; false killer whale; dwarf sperm whale; Gervais' beaked whale; and killer whale. As this study only focusses on the windward islands, these species are not further included in this chapter. Nevertheless, as in the future more observations undoubtedly will become available, it is likely that many of these species will eventually also be confirmed in the windward Dutch Caribbean.

\section{Bottlenose dolphin}

The bottlenose dolphin (Tursiops truncatus) (Figure 2) appears to occur in two different forms, a coastal form and an offshore form. It is the most common species observed in the windward Dutch Caribbean (Debrot et al. 2013a) and in the leeward Dutch Caribbean it is clearly a resident species (Debrot et al. 2011a). Given the large size of the Saba Bank, it seems likely that there may also likewise be a resident population of bottlenose dolphins on the bank. Debrot et al. (1998) mentioned that the bottlenose dolphin was the second most commonly sighted cetacean in the Leeward Dutch Antilles and more recently there were 41 sightings reported for the bottlenose dolphin for the leeward Dutch Caribbean, which is the largest number of records for all cetacean species recorded for the leeward Dutch Caribbean (Debrot et al. 2011a).

The observation of a new-born calf (Debrot et al. 2011a) could suggest that the coastal waters of Bonaire could be of importance to bottlenose dolphins. Other regions of the Caribbean have resident populations of this species that are well-documented through photo-identification studies (e.g. Campbell et al. 2002, Grigg \& Markowitz 1997, Kerr et al. 2005, Rogers et al. 2004). Observations are also known for the windward Dutch Caribbean, for example within the territorial waters of St Maarten (Nature Foundation St Maarten 2011). A total of 19 individuals were observed with the largest pod being seven (7) individuals. Very few juveniles were recorded. It is interesting to note that most individuals were observed within a specific geographic range, which may suggest that St Maarten could also have a resident population of bottlenose dolphins (Nature Foundation St Maarten 2011). 


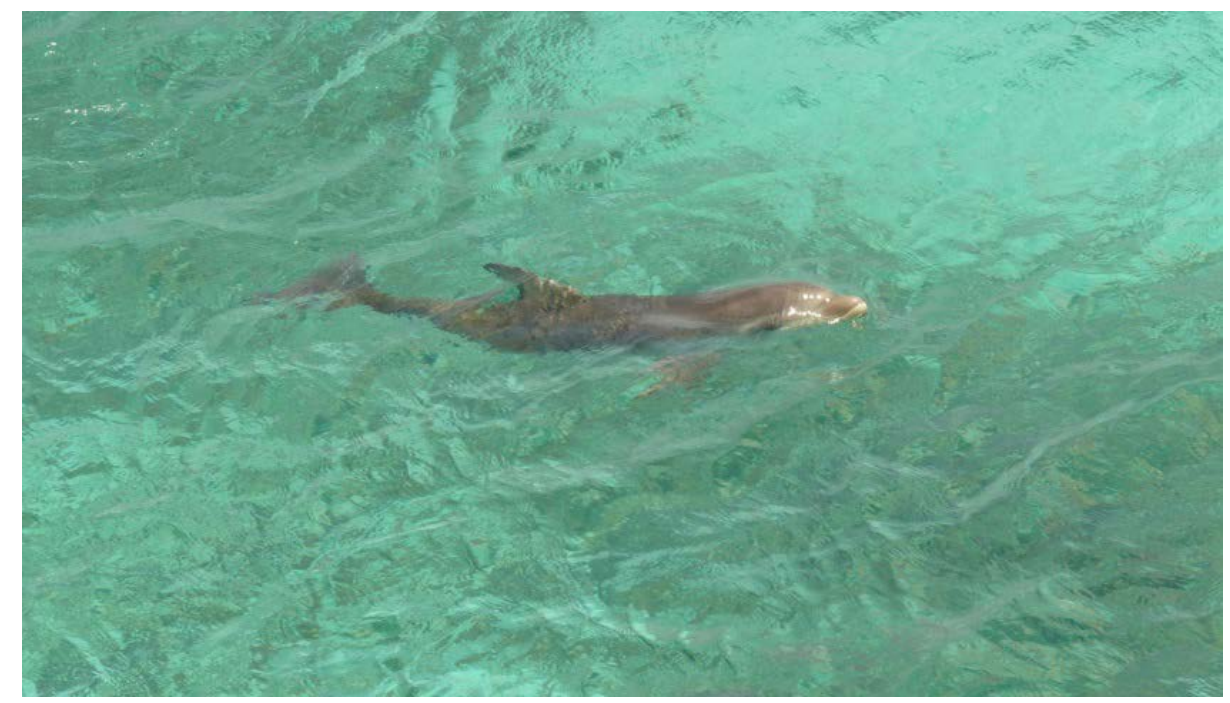

Figure 2 Juvenile bottlenose dolphin, Tursiops truncatus, temporarily separated from adults. Curaçao, 2008. Photo: Frederick Winkel.

\section{Spinner dolphin}

Spinner dolphins (Stenella longirostris) are fairly common in the waters of the leeward Dutch islands. Next to the bottlenose dolphin the spinner dolphin has the largest number of records (Debrot et al. 2011a). They are seen throughout the year with highest number of sightings in July and August (Debrot et al. 2011a). This species was also recorded at the windward Caribbean (nine individuals, Figure 3), within the territorial waters of St Maarten (Nature Foundation St Maarten 2011).

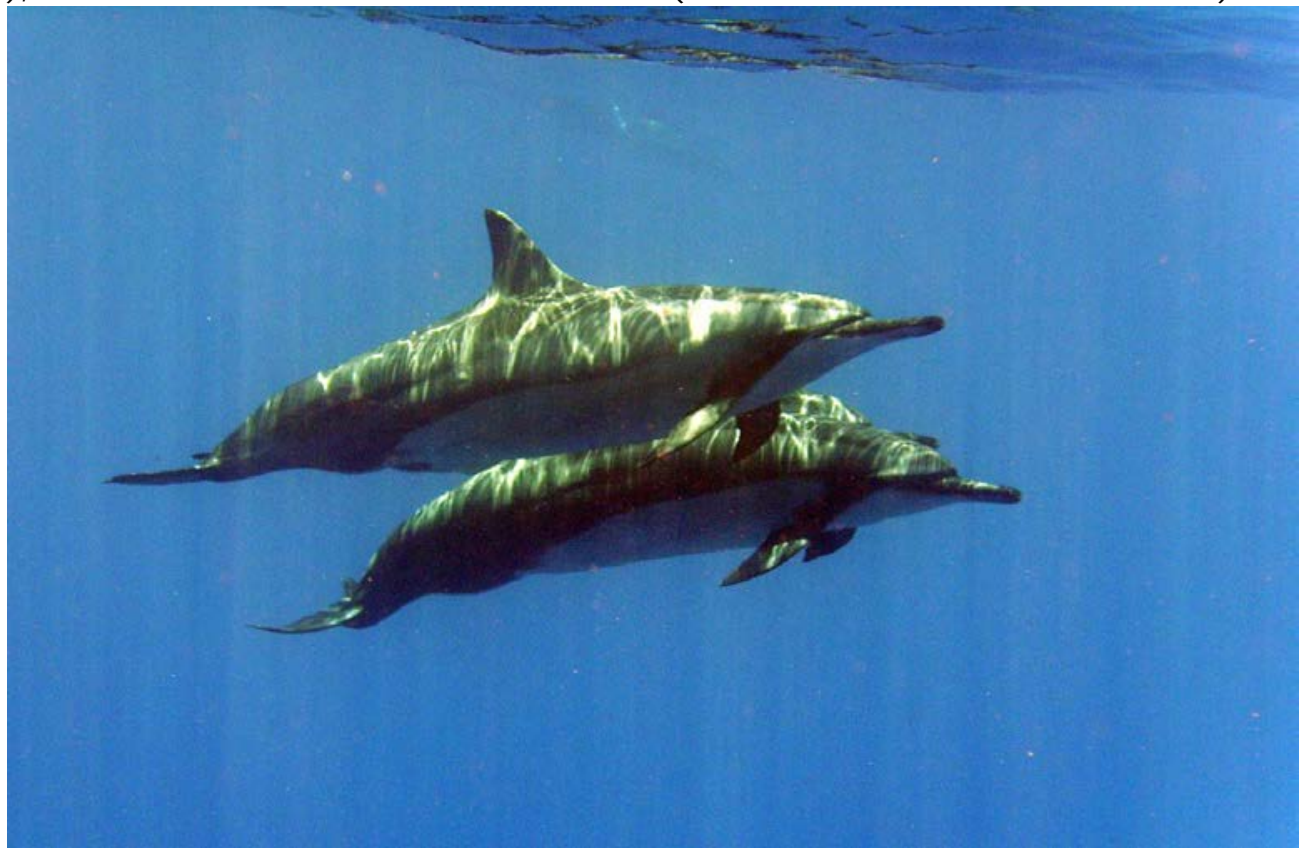

Figure 3 Spinner dolphins, Stenella longirostris, off Curaçao. Photo: Mark Vermeij.

\section{Atlantic spotted dolphin}

Although very common in surrounding waters, the Atlantic spotted dolphin (Stenella frontalis, Figure 4) was, until recently, not known for the waters of the leeward Dutch Islands. However, several records now exist for Aruba, (also seen with at least one calf among them) (Debrot et al. 2011a; Luksenburg 2013) and the species was sighted alive near the windward island of St Maarten (see Table 2). Debrot et al. (2013a) describe the Atlantic spotted dolphin as a likely species for the windward Islands, as it is relatively common in shallow shelf areas of Puerto Rico and the Virgin Islands and several records to the immediate north and east of the windward Dutch Caribbean waters are known. 


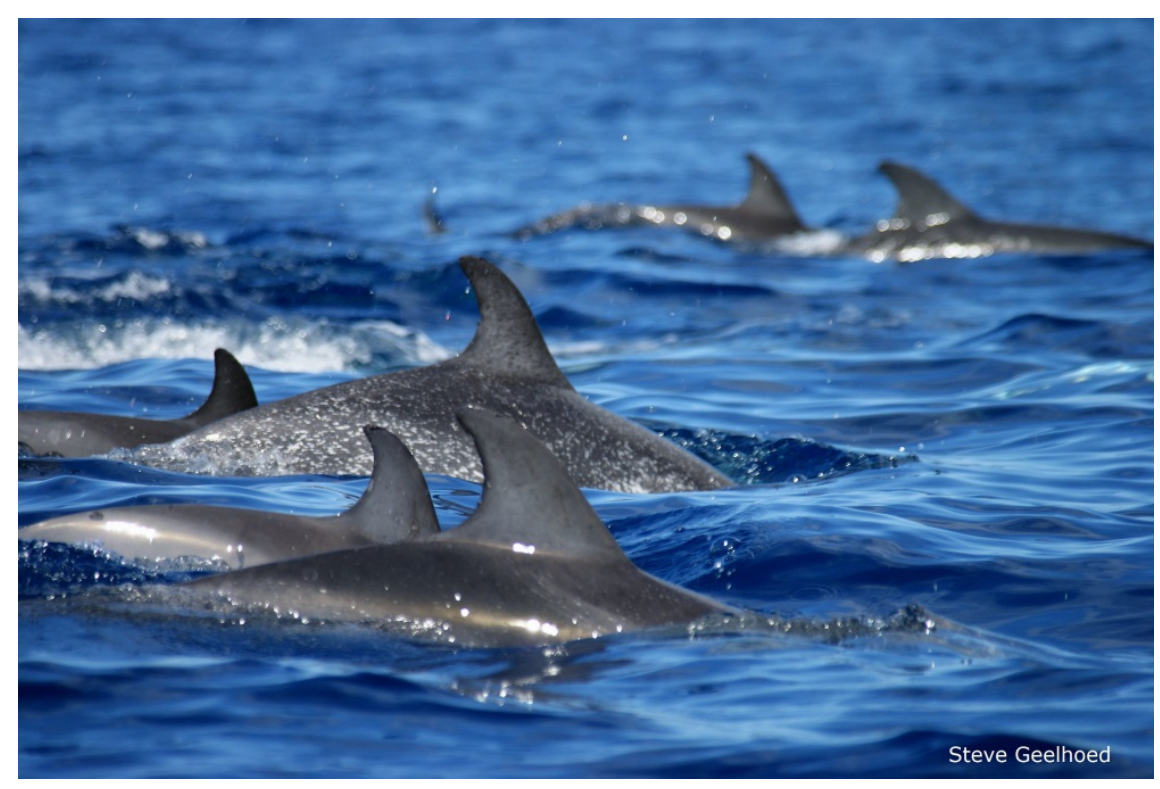

Figure 4 Spotted dolphin (Stenella frontalis). Photo: Steve Geelhoed.

\section{Short-finned pilot whale}

Short-finned pilot whales (Globicephala macrorhynchus) are found in warm temperate to tropical waters of the world, generally in deep offshore areas and within south of $50^{\circ} \mathrm{N}$ and north of $40^{\circ} \mathrm{S}$ (Taylor et al. 2011). Focusing on the Dutch Caribbean, it is a native species of Aruba, Bonaire, Sint Eustatius, Saba, Curaçao and St Maarten (Dutch part) (Taylor et al. 2011). The species is listed on the Red List as Data Deficient.

Short-finned pilot whales show the tooth reduction typical of other squid-eating cetaceans and, although they also take fish, are thought to be primarily adapted to feeding on squid (Taylor et al. 2011). They feed on vertically migrating prey, with deep dives at dusk and dawn following vertically migrating prey and near-surface foraging at night. These animals are typically found in highest densities over the outer continental shelf or continental slope (Taylor et al. 2011).

The occurrence of the short-finned pilot whale in the windward Dutch Caribbean is not surprising and is confirmed for the windward Dutch islands based on three records (Debrot et al. 2013a). In the leeward Dutch Caribbean at least two strandings and nine sightings of this species are known (Debrot et al. 2011a).

It appears to be regularly present in leeward Dutch Caribbean waters and was considered to be commonly sighted. Since 1998, however, it has only been sighted twice (groups in 2006 and 2009) and one stranding was reported in 2009 (Debrot et al. 2011a). Two recent strandings are reported for Aruba (Luksenburg 2013).

\section{Humpback whale}

The humpback whale is a large whale with a length of ca. $16 \mathrm{~m}$ (Figure 5). Humpback whales have a cosmopolitan distribution that generally involves long migrations between high-latitude summer feeding grounds and tropical breeding grounds (e.g. Clapham 2000). NOAA Fisheries identified 14 Distinct Population Segments (DPS). In the North Atlantic, the humpback whale ranges from tropical waters in the Caribbean to Arctic waters (Meesters et al. 2010). In the north-eastern Caribbean this species occurs principally between November and May (Debrot et al. 2013a). Humpback whale song was detected in the US Stellwagen marine sanctuary in two distinct periods (Stanistreet et al. 2013): spring (March through J une, with a marked peak in the middle of April) and fall (August through December, with a less pronounced peak in late November). No song was recorded during either the summer months (mid-J une to mid-August) or winter months (J anuary to mid-March). 


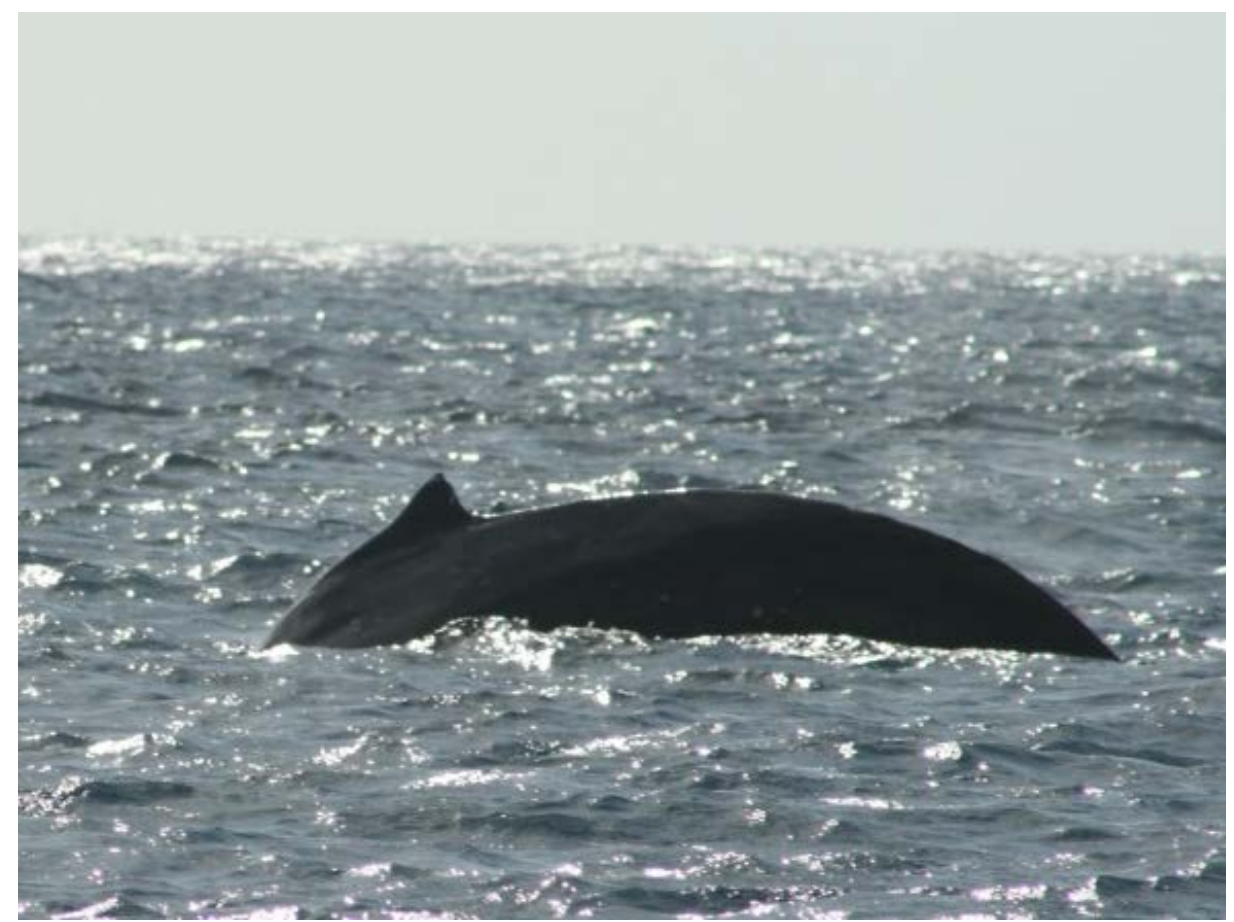

Figure 5 Humpback whale, Megaptera novaeangliae, off Daaibooi, Curaçao, 2008. Courtesy Cees van Dongen.

Within the territorial waters of St Maarten, 33 individuals (including calves) were recorded in 2011, with the highest density in March (Nature Foundation St Maarten 2011).

While the breeding and calving grounds to the east of the windward Dutch waters are currently well established, this is not the case for the area of the Saba Bank. Sighting records of mother and calves suggest that the area around the windward Dutch islands may form part of the former (or current) calving grounds of the humpback whale (Debrot et al. 2011a). Humpback whales in the Caribbean are strongly associated with banks and other shallow waters (Meesters et al. 2010; Debrot et al. 2013a). The presence of relatively warm shallow bank habitat could indicate that this area might also serve as calving ground to the recovering population of western Atlantic humpbacks (Debrot et al., 2013a). Further research will be needed to determine if this is true.

There is little information on the summer feeding grounds used by the humpback whales that winter in the Eastern Caribbean and on the relationships between individuals wintering in the Eastern Caribbean waters to those in other feeding and breeding areas. Applying photo-identification or genetic sampling techniques could help address these information gaps (Meesters et al. 2010). Stevick et al. (2014) have found evidence suggesting that the humpback whales of the south-eastern Caribbean may represent a distinct migratory group arriving later on their calving grounds than the group calving around the Dominican Republic and feeding principally off Europe instead of off Canada and the USA.

The humpback whale was formerly listed on the IUCN status as Vulnerable (under the 1996 categories and criteria), see Annex 1, but is now listed at least concern with an increasing trend. Debrot et al. (2011a) report that humpback whales sightings amounted to $45 \%$ of all records around the windward Dutch islands but remained relatively rare in the leeward sector ( $5 \%$ of records). Thus they are more common around the windward Dutch islands compared to the leeward Dutch islands. The windward sector may form part of its former (or current) calving grounds (Debrot et al. 2011a). A recent study using passive acoustics (Risch \& de Haan 2016) has confirmed the seasonal occurrence of humpback whales in the region around Saba Bank.

\section{Minke whale}

Although the common minke whale (Balaenoptera acutorostrata) is listed in Table 2 as "possible occurring, no sightings confirmed", this species is probably common in the windward Dutch Caribbean, as indicated by acoustic detections at Saba Bank (Risch et al. 2014; Risch and de Haan 2016). Common minke whales are found in oceans all over the world. During the winter they typically travel toward warmer waters and in summer move closer to the poles. It has been suggested that the North Atlantic minke whale has a more offshore occurrence on their northbound migration and a more 
coastal distribution later in the year when the whales are headed south (Risch et al., 2014). The study of Risch et al. (2014) confirms the seasonal migration of North Atlantic minke whales offshore the eastern US continental shelf in spring and autumn and their winter presence in south eastern US and Caribbean waters. Several (48) detections were made at the inshore Saba Island site during winter and spring (February to April), indicating that whales are moving closer inshore during winter months (Risch et al. 2014).

\section{Sperm whale}

Sperm whales (Physeter macrocephalus) (Figure 6) are relatively common both to the west and east of the windward Dutch Caribbean (Debrot et al., 2013a). They are largely restricted to deeper waters where they prey on deep water squid. In the north-eastern Caribbean they are strongly seasonal and are rarely seen from April through September (Mignucci-Giannoni 1998). For the windward Dutch Caribbean, all five sightings recorded are for the first quarter of the year (Debrot et al. 2011a). For the leeward Dutch Caribbean, six strandings (including fishery-related strandings) and two sightings are known, including Aruba (Debrot et al. 2011a; Luksenburg 2013).

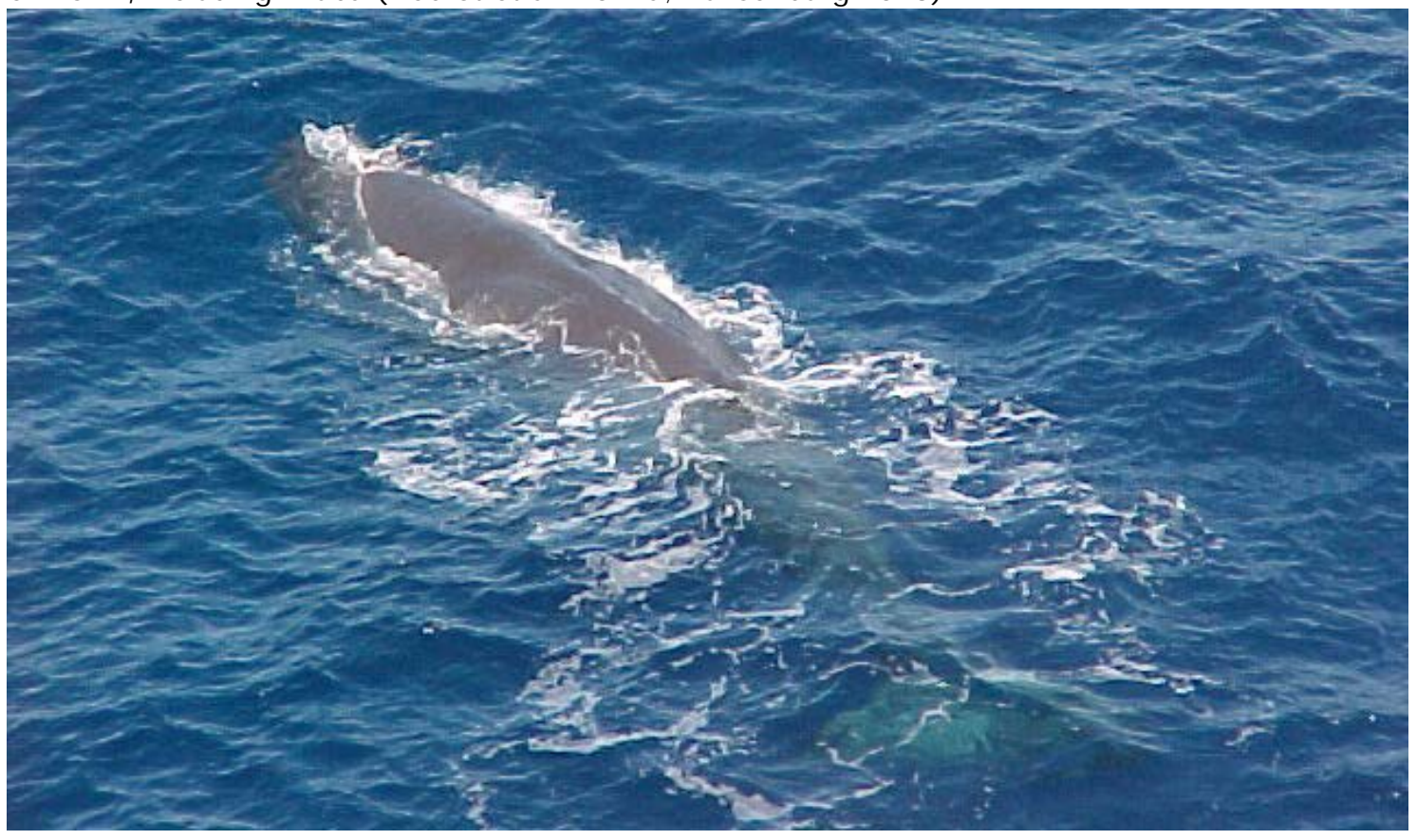

Figure 6 Sperm whale (Physeter macrocephalus) off Curaçao. Photo: Dutch Caribbean Coast Guard.

\section{Cuvier's beaked whale}

Cuvier's beaked whale (Ziphius cavirostris) is listed for the windward Dutch Caribbean based on one published stranding record (van Bree et al. 1973). For the leeward Dutch Caribbean there are six known strandings and one sighting (Debrot et al. 1998). The species likely occurs in deep basins along most coasts and in areas where the continental shelf is narrow and coastal waters are deep such as around many oceanic islands. Squid and crustaceans are part of their diet (Debrot et al. 2011a). 


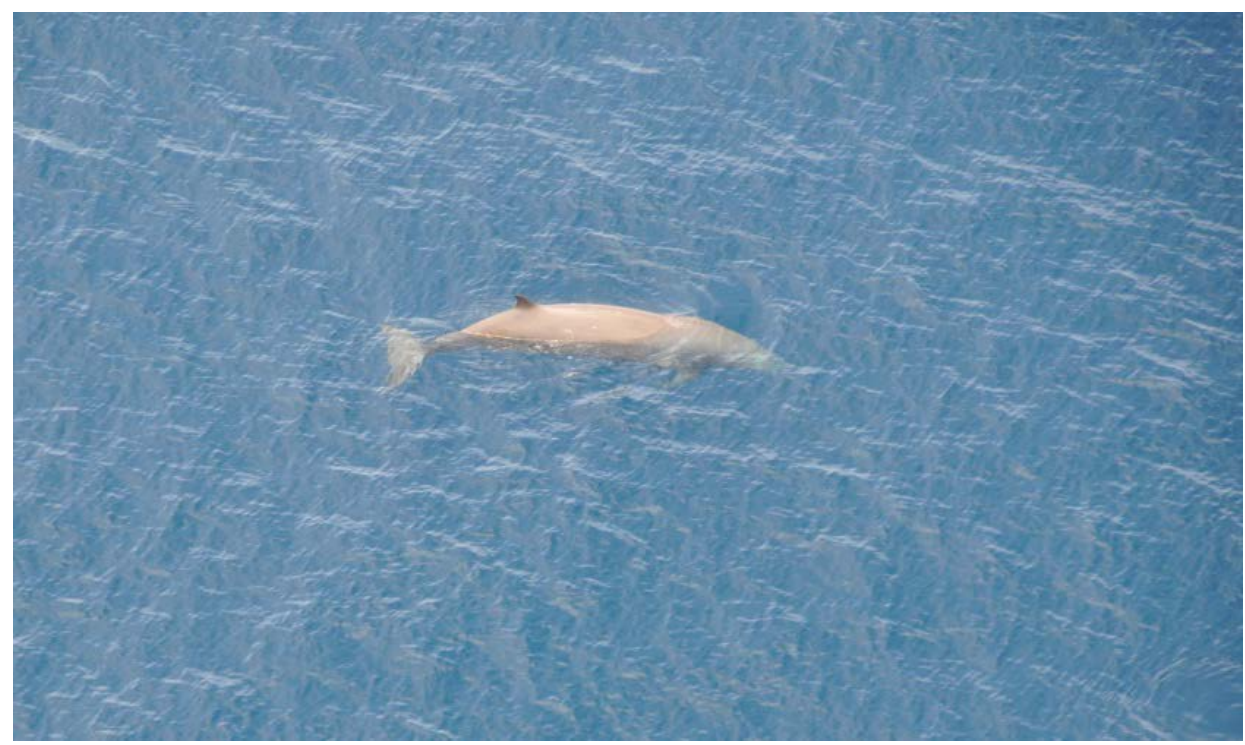

Figure 7 Cuvier's beaked whale, Ziphius cavirostris, off Curaçao. Photo: Dutch Caribbean Coast Guard.

\section{West I ndian manatee}

The West Indian Manatee (Trichechus manatus) is currently divided into the Florida (T. m. latirostris) and Antillean (T. m. manatus) subspecies (Deutsch et al. 2008). The West Indian manatee is a native species of Bonaire and Curaçao and regionally extinct in Saba, Sint Eustatius, Aruba and St Maarten (Dutch part) (Deutsch et al. 2008). This species is becoming rare and even endangered in most countries in which is still occurs (Debrot et al. 2006).

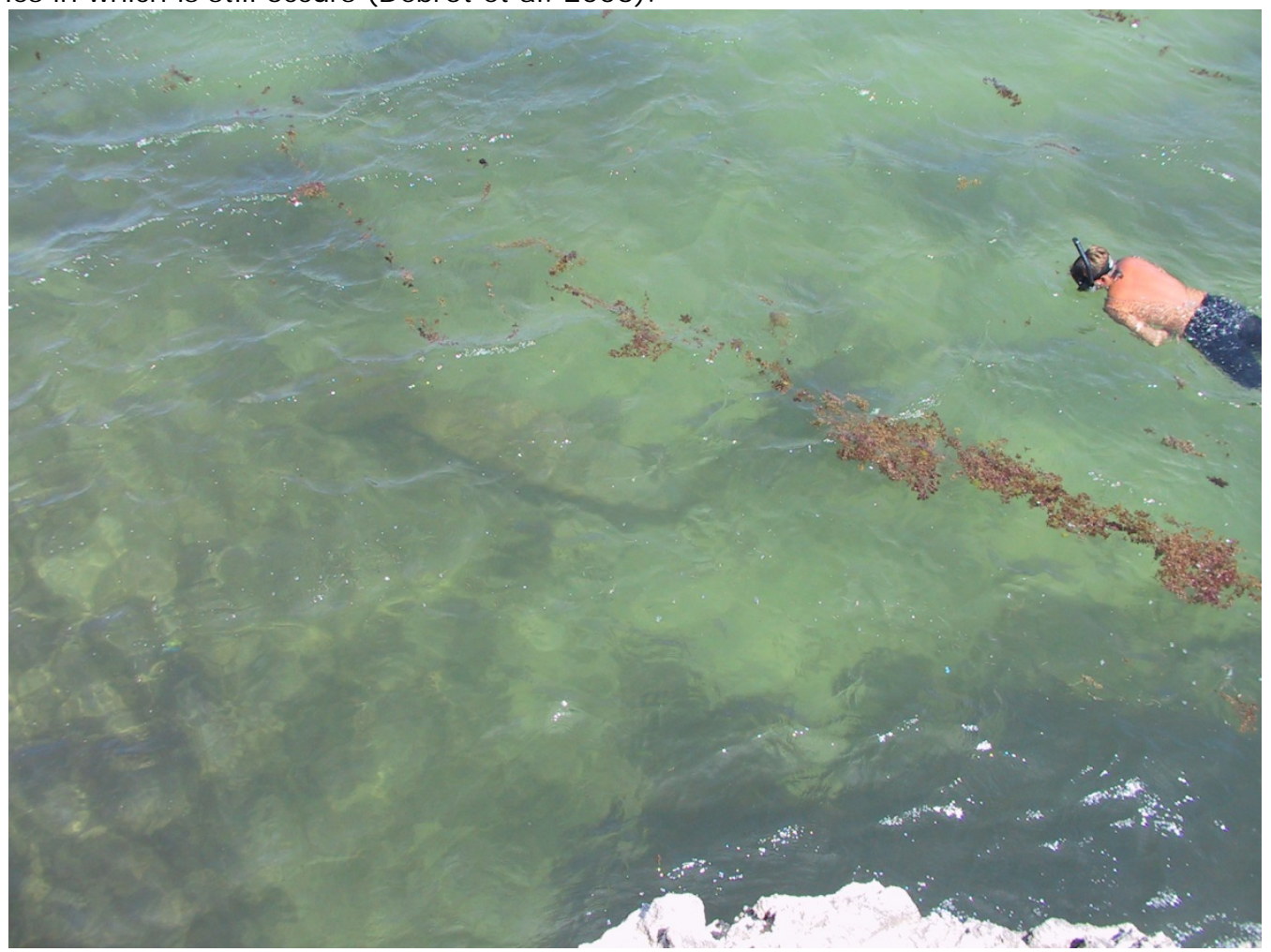

Figure 8 Outline of a manatee on the lagoon bottom, center of image. Boka Ascencion, Curaçao, 2005. Photo: A. Debrot

Manatees are herbivores that feed opportunistically on a wide variety of submerged, floating, and emergent vegetation (Deutsch et al. 2008). The species is typically associated with estuarine and seagrass habitat. They show a strong preference for freshwater, although it is still unknown to what extent the manatee requires periodic access to freshwater for survival. It is possible that freshwater availability on Curaçao and possibly Aruba and Bonaire, could have supported small populations of the manatee (Debrot et al. 2006). Today, in and around the leeward islands, suitable habitat is clearly absent, and therefore this species only occurs sporadically with three sightings for Curaçao so far 
(Debrot et al. 2006). Sightings suggest that manatees are capable of reaching the Dutch Leeward Islands and this area could still form part of their active range (Debrot et al. 2006). One reliable recent record for the West Indian manatee in the Dutch Caribbean windward Islands was listed (Debrot et al. 2013a). The only recently suitable habitat for this species in the windward Dutch Caribbean is the Simpson Bay Lagoon of St Maarten, where the last sighting was also recorded in the late 1980s (Debrot et al. 2006).

\subsubsection{Regional comparison of distribution}

The Saba and Saba Bank Yarari sector has a relatively high documented marine mammal species richness within the Wider Caribbean Region (Figure 9).

\section{Marine Mammal Protection and Species Richness}

in the Wider Caribbean Region

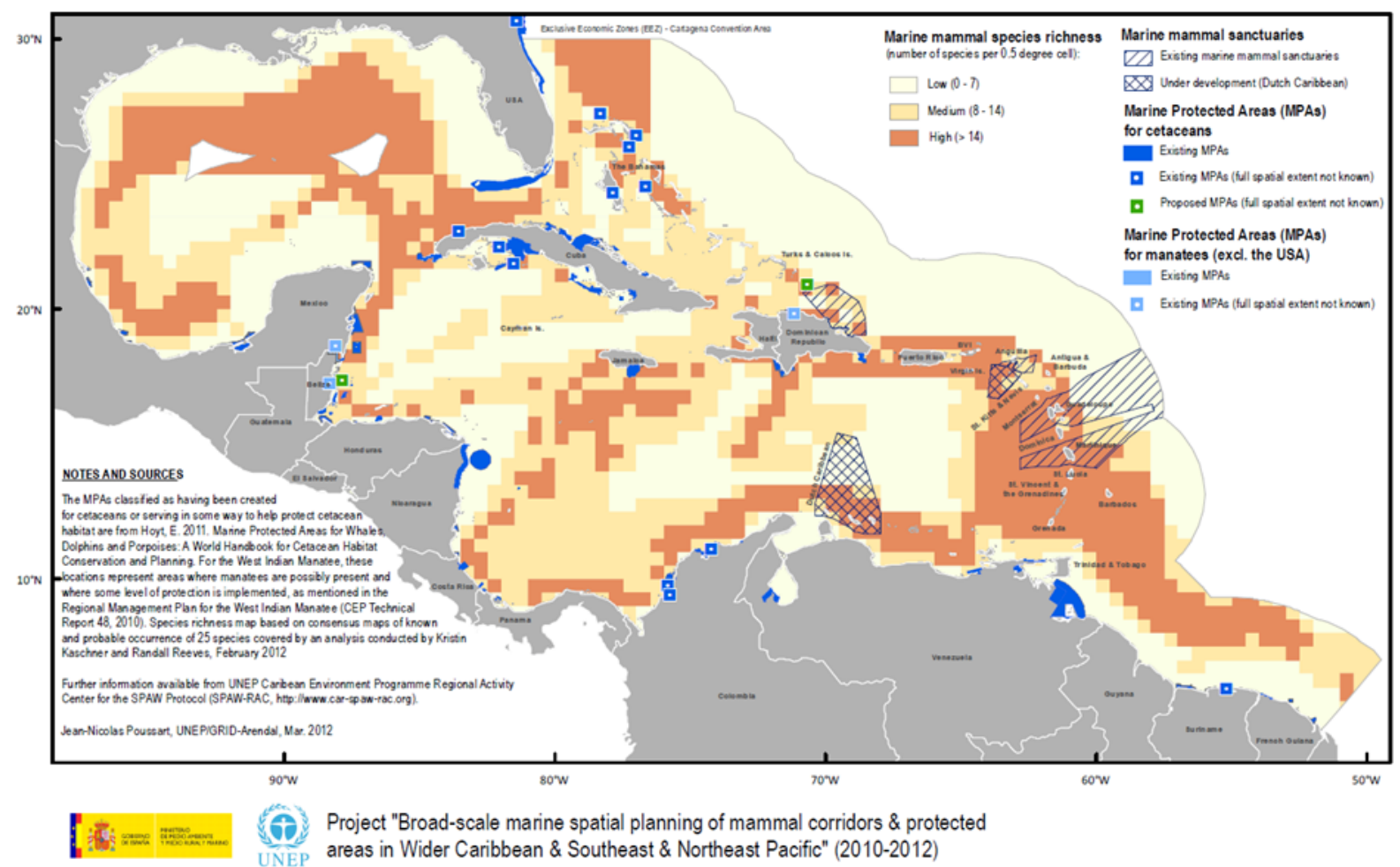

Figure 9 Marine mammal species richness of the Wider Caribbean Region (Poussart 2012). Note: this figure presents an ideal version of the Yarari Sanctuary boundaries (indicated as 'under development'). In its current realisation the southern part of Yarari Sanctuary is considerably smaller than its ultimate potential size as it currently does not include the EEZs of Aruba or Curaçao but only the EEZ of Bonaire), see Figure 1.

The spatial distribution of known and probable occurrence of marine mammal species in part of the WCR is presented in Figure 10 to Figure 12. In summary, these figures make it clear that the Saba and Saba Bank Yarari sector lie in an area rich with cetacean species and that the only reason only 9 marine mammal species have so far been confirmed for the windward sector of the Dutch Caribbean is the lack of documented observations. 


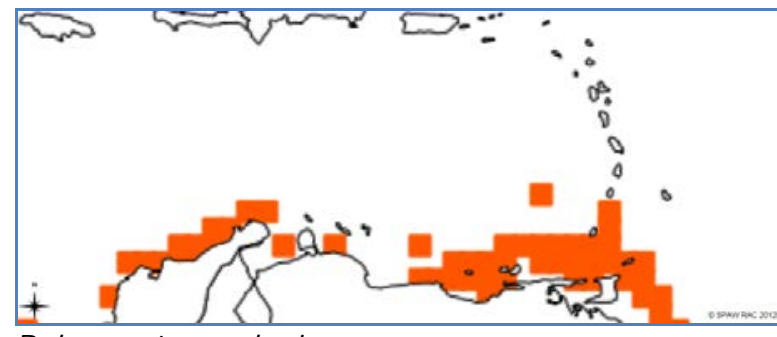

Balaenoptera edeni

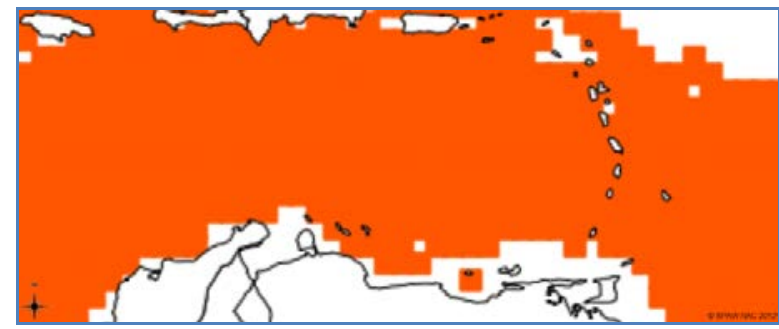

Feresa attenuata

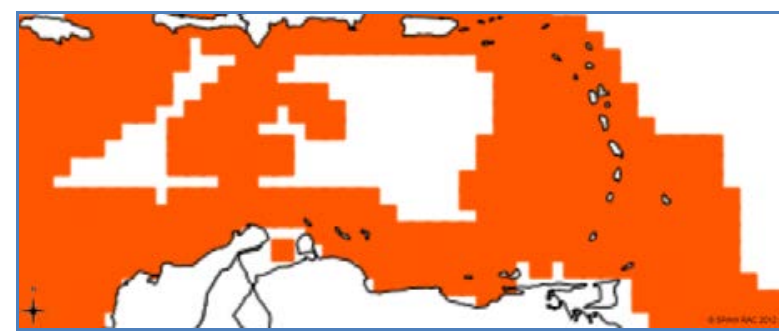

Grampus griseus

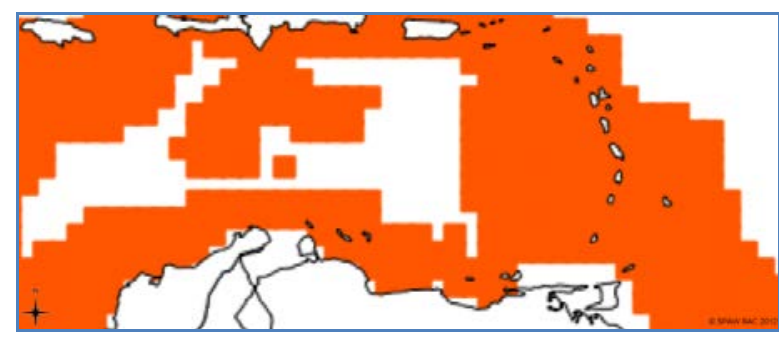

Kogia sima

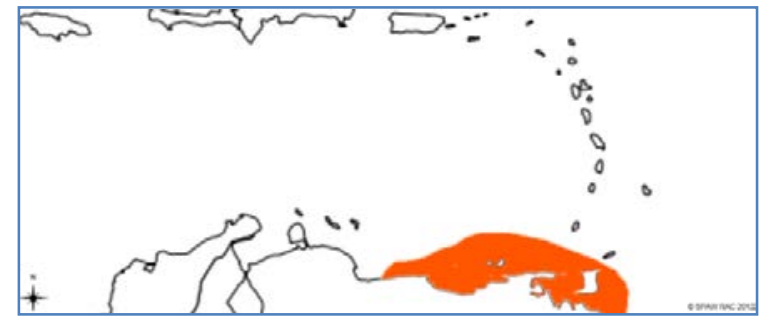

Delphinus capensis

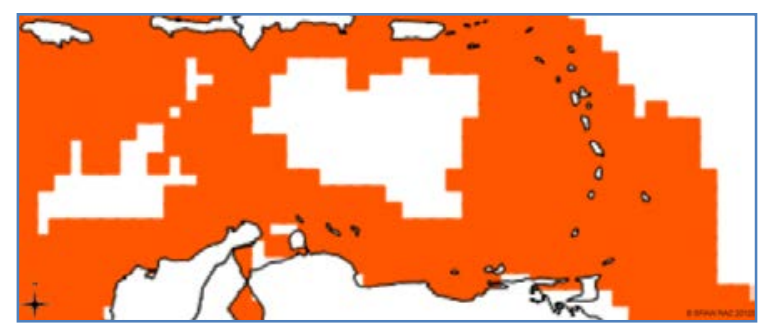

Globicephala macrorhynchus

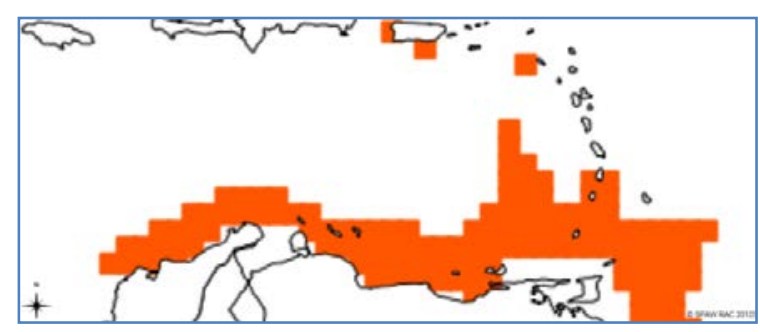

Kogia breviceps

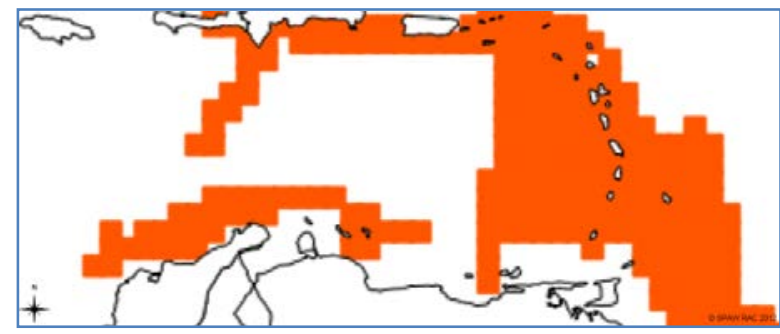

Lagenodelphis hosei

Figure 10 Distribution of known and probable occurrence of marine mammal species (SPAW-RAC 2012). 


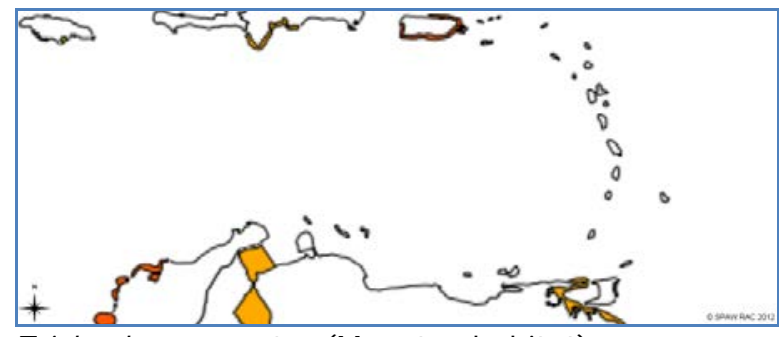

Trichechus manatus (Manatee habitat)

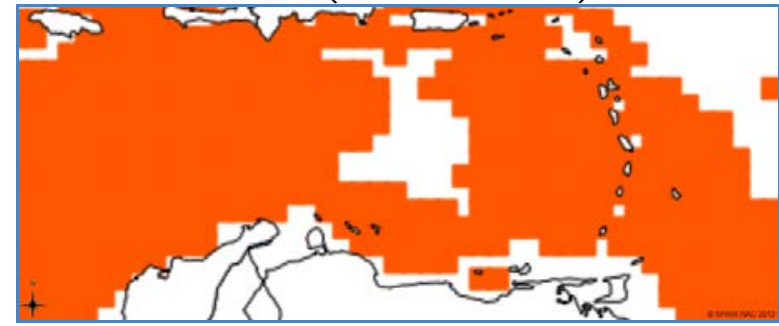

Mesoplodon densirostris

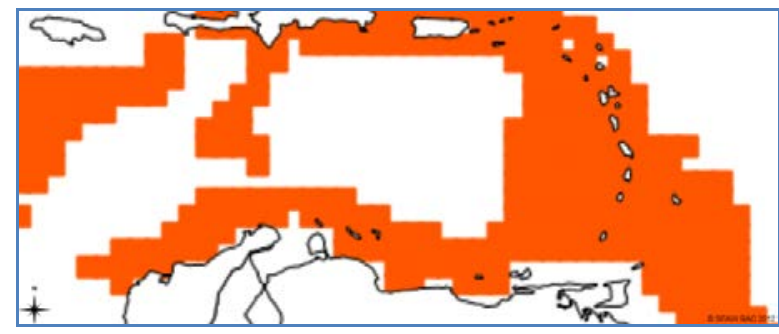

Orcinus orca

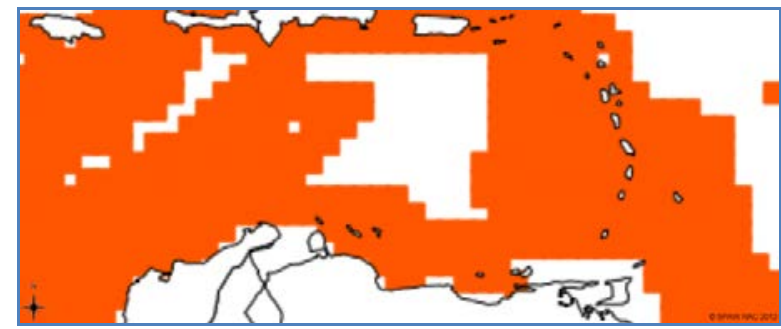

Physeter macrocephalus

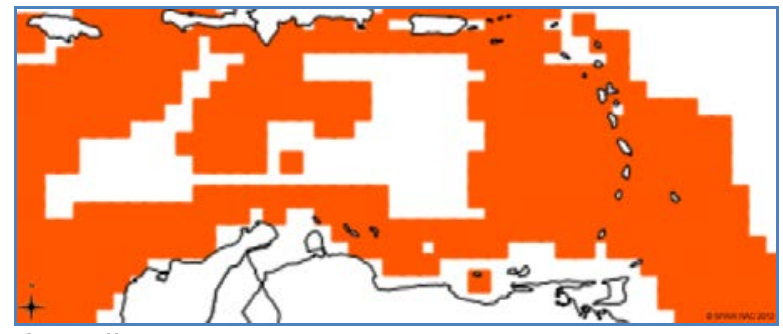

Stenella attenuata

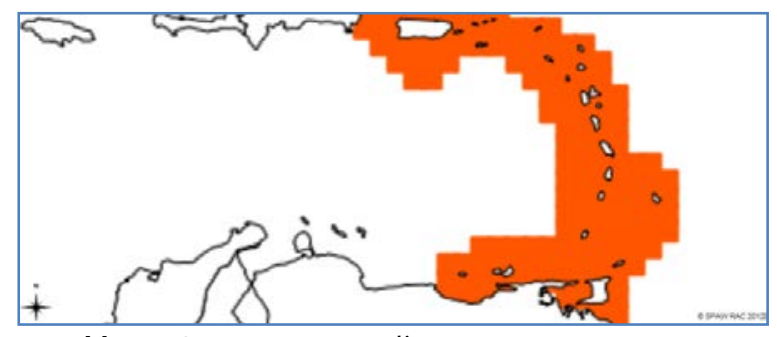

Megaptera novaeangliae

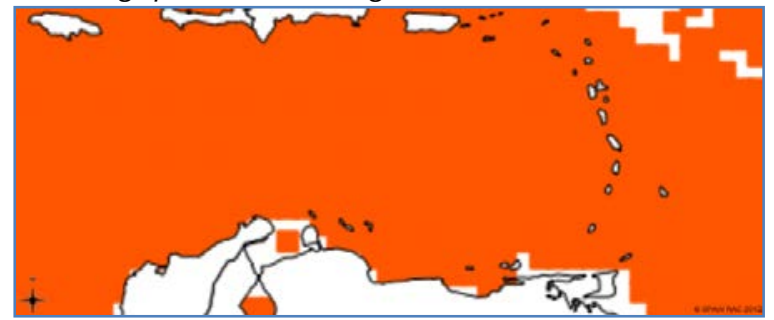

Mesoplodon europaeus

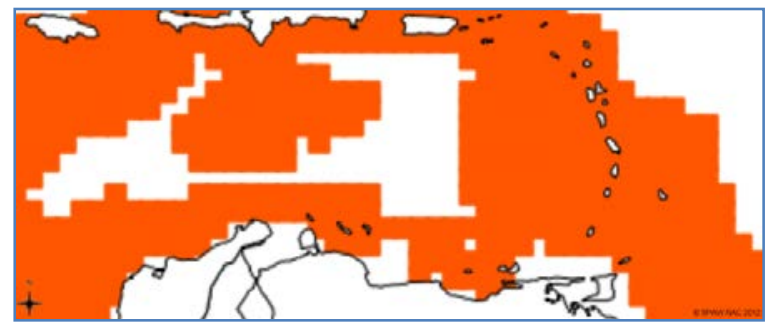

Peponocephala electra

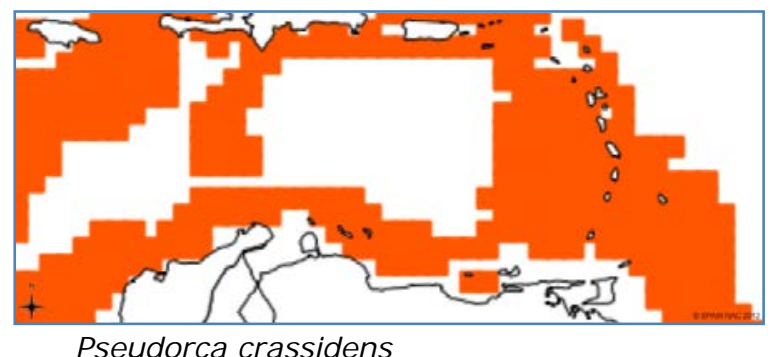

Pseudorca crassidens

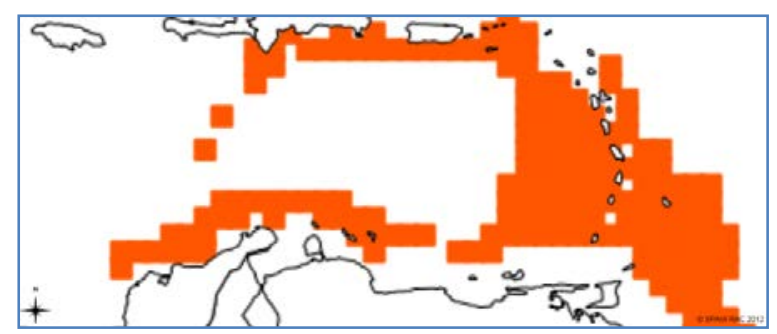

Stenella clymene

Figure 11 Distribution of known and probable occurrence of marine mammal species, continued (SPAW-RAC 2012). 


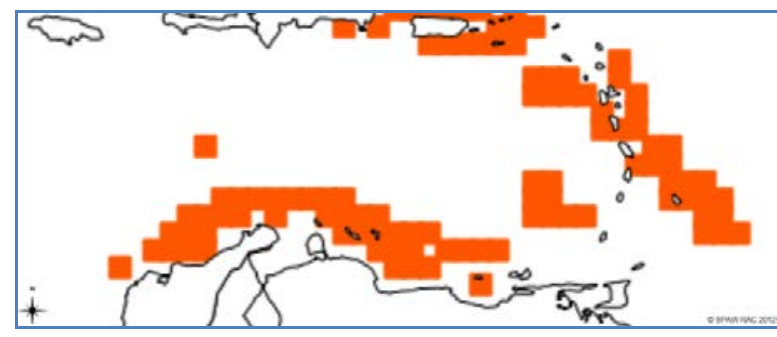

Stenella coeruleoalba

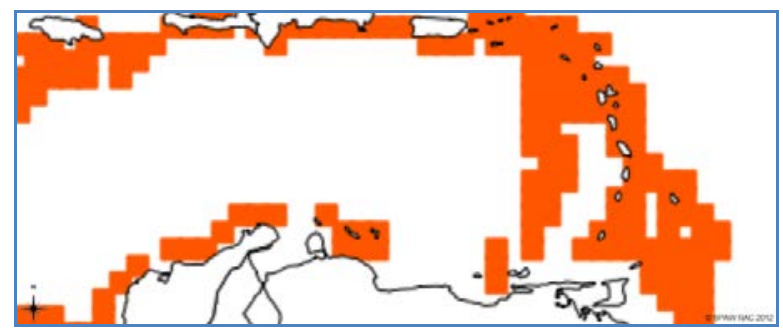

Stenella longirostris

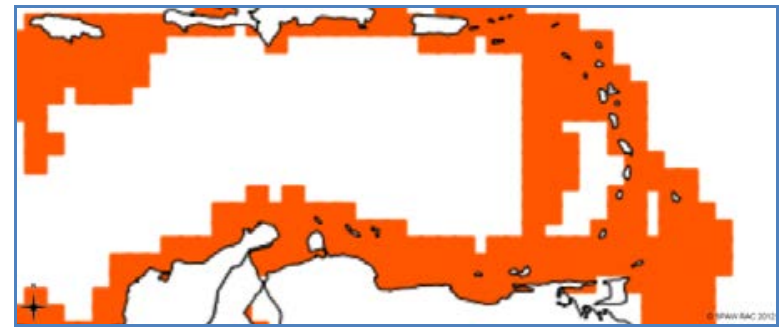

Tursiops truncatus

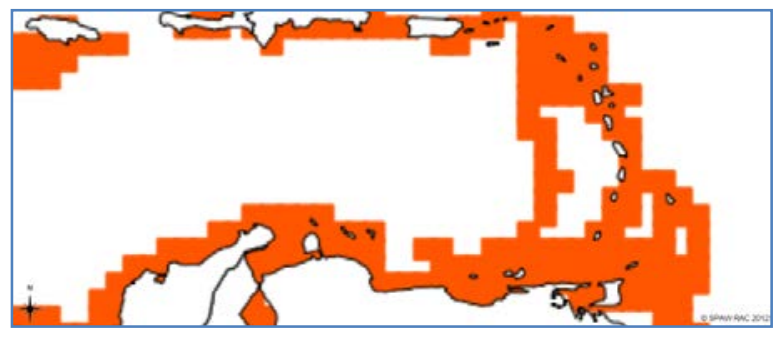

Stenella frontalis

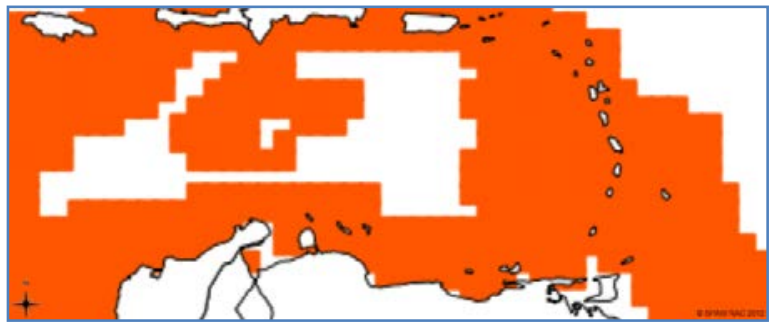

Steno bredanensis

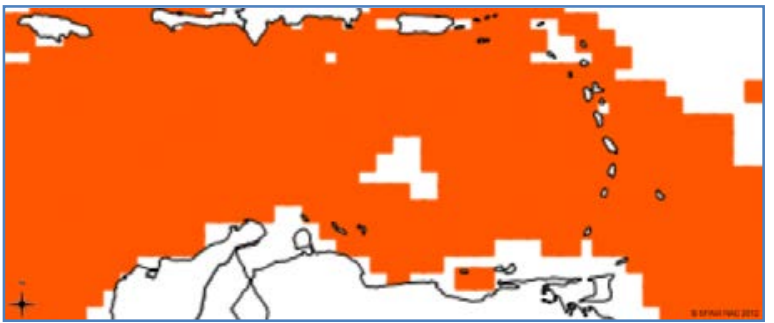

Ziphius cavirostris

Figure 12 Distribution of known and probable occurrence of marine mammal species, continued (SPAW-RAC, 2012).

Opportunistic data collected by fishermen indicated that the relative density (sightings per "fishing trip") showed a pronounced difference in occurrence of cetaceans between islands. The highest relative density of dolphins was found in Bonaire with 0.16 dolphin sightings/fishing trip. Data indicated that an area on the west side of the island and close to shore $(<1 \mathrm{~km})$ with high fishing effort also had a high occurrence of cetacean sightings (Scheidat et al., 2015). In contrast, the highest relative sighting density of whales was found in Saba with 0.04 whales/fishing trip (Scheidat et al., 2015). Available data indicates that dolphins also occur regularly on the Saba Bank (Scheidat et al., 2015). It is likely that a shallow area as large as the Saba Bank could play an important role for marine mammals in a mostly much deeper region (Meesters et al., 2010). Habitat suitability for the humpback whale in and around the Yarari Sanctuary is presented in Figure 13. It shows that especially the northern part of Yarari, which is the focus of this study, has a relatively high humpback whale habitat suitability. 


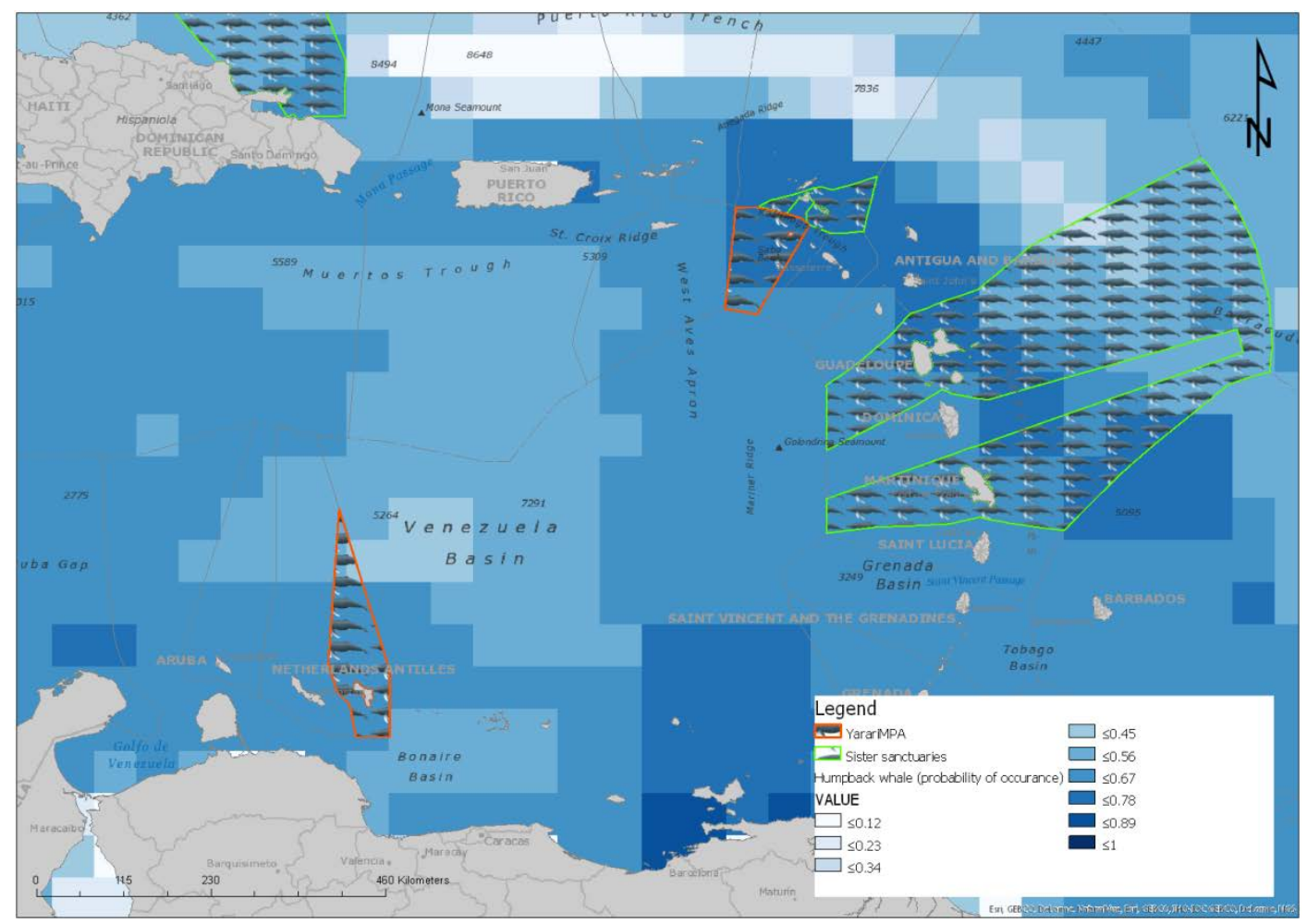

Figure 13 Humpback whale habitat suitability (Kaschner et al., 2015). The suitability is presented as the overall probability of occurrence ranging from 0 to 1.

\subsubsection{Temporal distribution}

The temporal distribution of species of the windward Dutch Caribbean is presented in Table 3. Known migratory species that are only present part of the year in the windward Dutch Caribbean are humpback whale (October-June), common minke whale (February-April) and sperm whale (OctoberMarch). Data on the occurrence of manatees in the area is too scarce to indicate a temporal distribution of the species. It is, however, known that manatees undertake extensive seasonal migrations, with seasonal distribution determined by water temperature (Deutsch et al. 2008). All other species are likely to be resident species in the area of the windward Dutch Caribbean, even if not confirmed throughout the year (Table 3).

Opportunistic data collected by fishermen indicated seasonal patterns in occurrence of whales and dolphins, in particular for Saba waters where monitoring was done for several years. Most whale and dolphin sightings were in March (Scheidat et al. 2015). During a short dedicated shipboard survey at the Saba Bank, conducted from 22-26 October 2011, no marine mammals were observed (Geelhoed and Verdaat 2012).

Table 3 Temporal distribution of species known to occur in the windward Dutch Caribbean

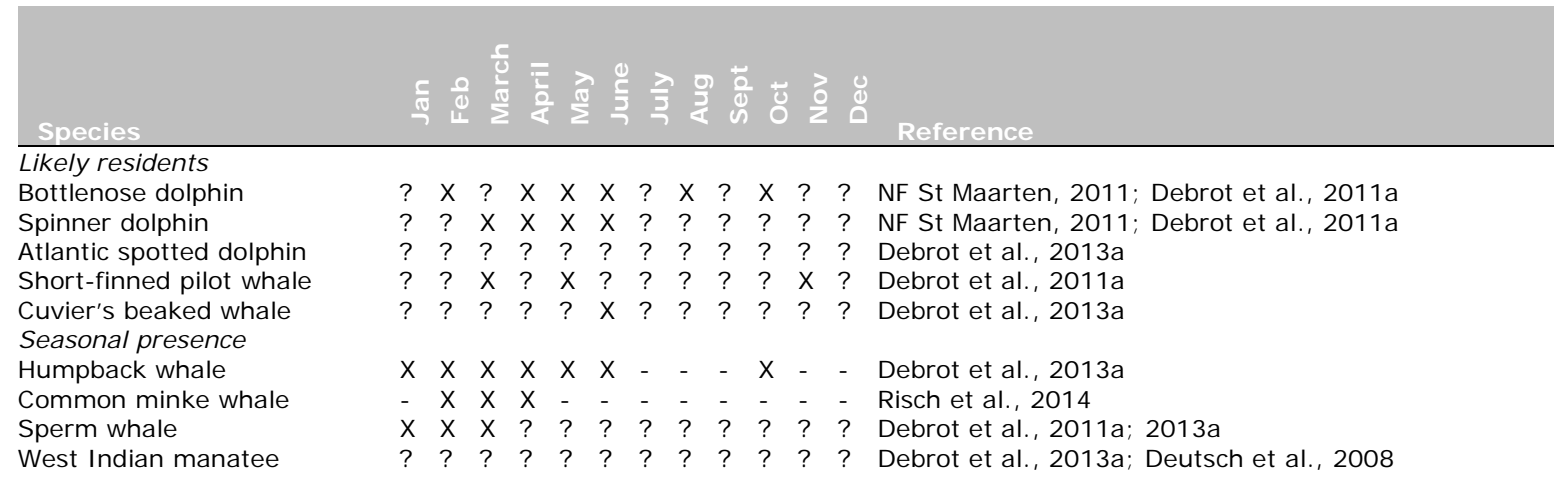

?: Likely occurrence; X: reported sightings/observations; -: unlikely occurrence 


\subsection{Potential impact of human activities}

Human activities can have a negative impact on cetaceans. The severity of an impact can range from a brief change of behaviour to death and it can be relevant to only an individual or affect a whole population. In this chapter we would like to highlight human activities that are known to be negative for cetaceans, which of these are most likely present in the northern part of the Yarari Sanctuary and what kind of data is needed to assess the potential impact (if any) they might have.

The following activities/pressures are addressed in this chapter:

- Fishery (entanglement \& bycatch, directed hunt, overfishing);

- Noise pollution (marine mammal sound production and noise, anthropogenic noise in the wider Caribbean);

- Collisions with vessels and ships

- Marine debris;

- Contaminants;

- Habitat degradation/physical barriers (marine \& coastal construction, collision, anchoring);

- Whale and dolphin watching;

- Climate change;

- Cumulative effects.

\subsubsection{Fishery}

Fisheries activities in the Dutch Caribbean EEZ areas are regulated under the BES Fisheries Law (Visserijwet BES, 25-01-2014), and the BES Fishery Ordinance (Visserijbesluit BES, 10-10-2010). The law regulates access for fishing and largely concerns permitting matters. The ordinance, on the other hand, lists such matters as gear and species restrictions. In these, a number of restrictions are of particular importance to marine mammals. The BES Fishery Ordinance prohibits 1) all taking of marine mammals, 2) the use of marine mammals as bait, 3) gill nets longer than $2.5 \mathrm{~km}$. This means that typical fisheries activities that impact cetaceans such as the use of long-lines, the use of tuna purse seines and the use of drifting gillnets are poorly regulated.

In practice however, permits for the use of such gears in the EEZ have not been given in recent years based on the argument that EEZ waters are overfished (S. Mambi, pers. comm. to A. Debrot). Illegal fishing, particularly by Venezuelan vessels is a recurrent problem that is rigorously addressed by the coastguard. However, the problem of incursions by illegal fishing vessels is largely restricted to the leeward sector of the EEZ. On average the coastguard attends about 40 cases annually (DCCG 2016). Fishery can have three main pressures on cetaceans: 1 ) entanglement $\&$ bycatch, 2) directed hunt or culling and 3) overfishing.

An indication of the fishing intensity in and around the Yarari Sanctuary is presented in Figure 14 (pelagic fishery) and Figure 15 (demersal fishery). 


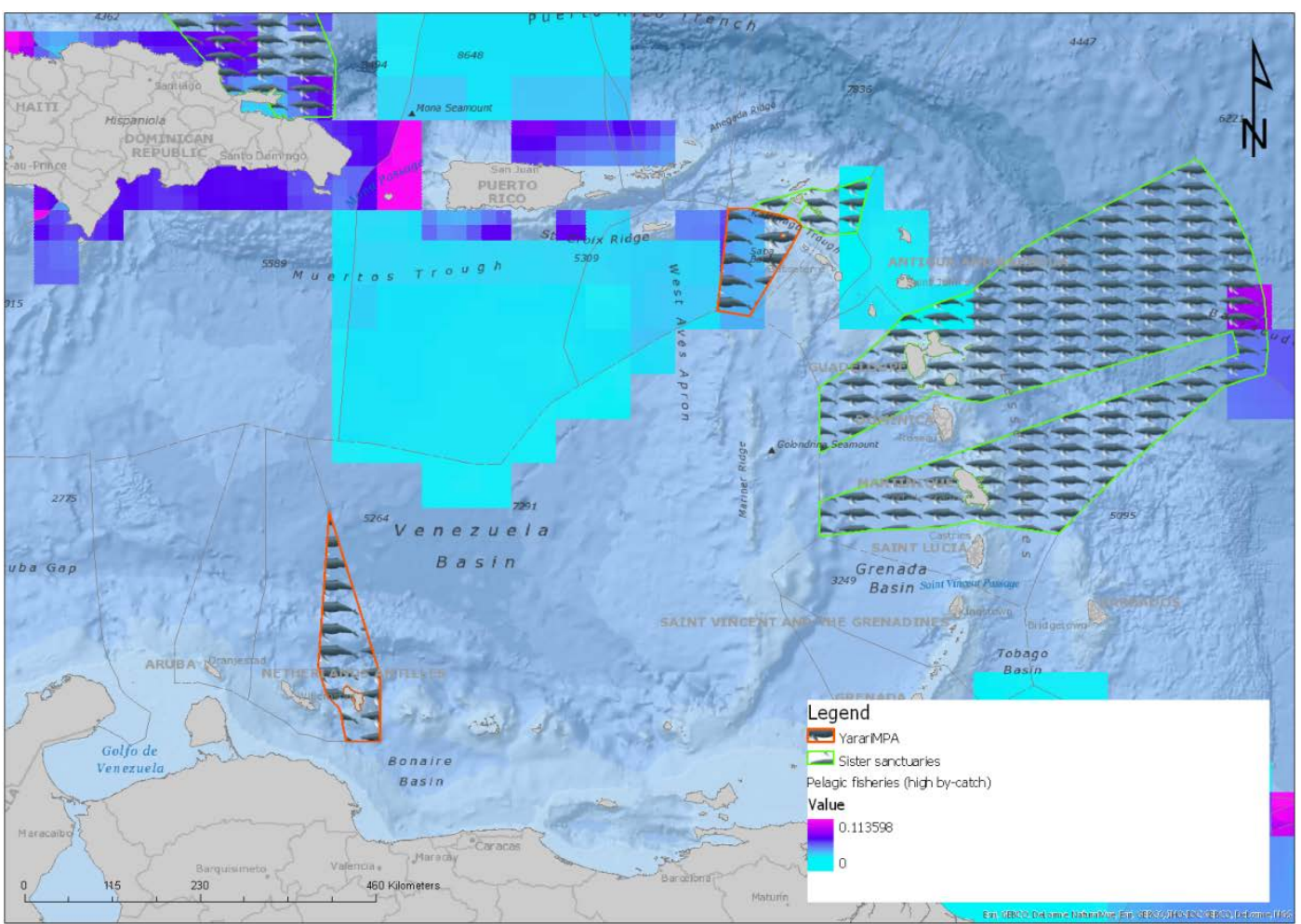

Figure 17 Pelagic fisheries / high by-catch (source: Halpern et al. 2015).

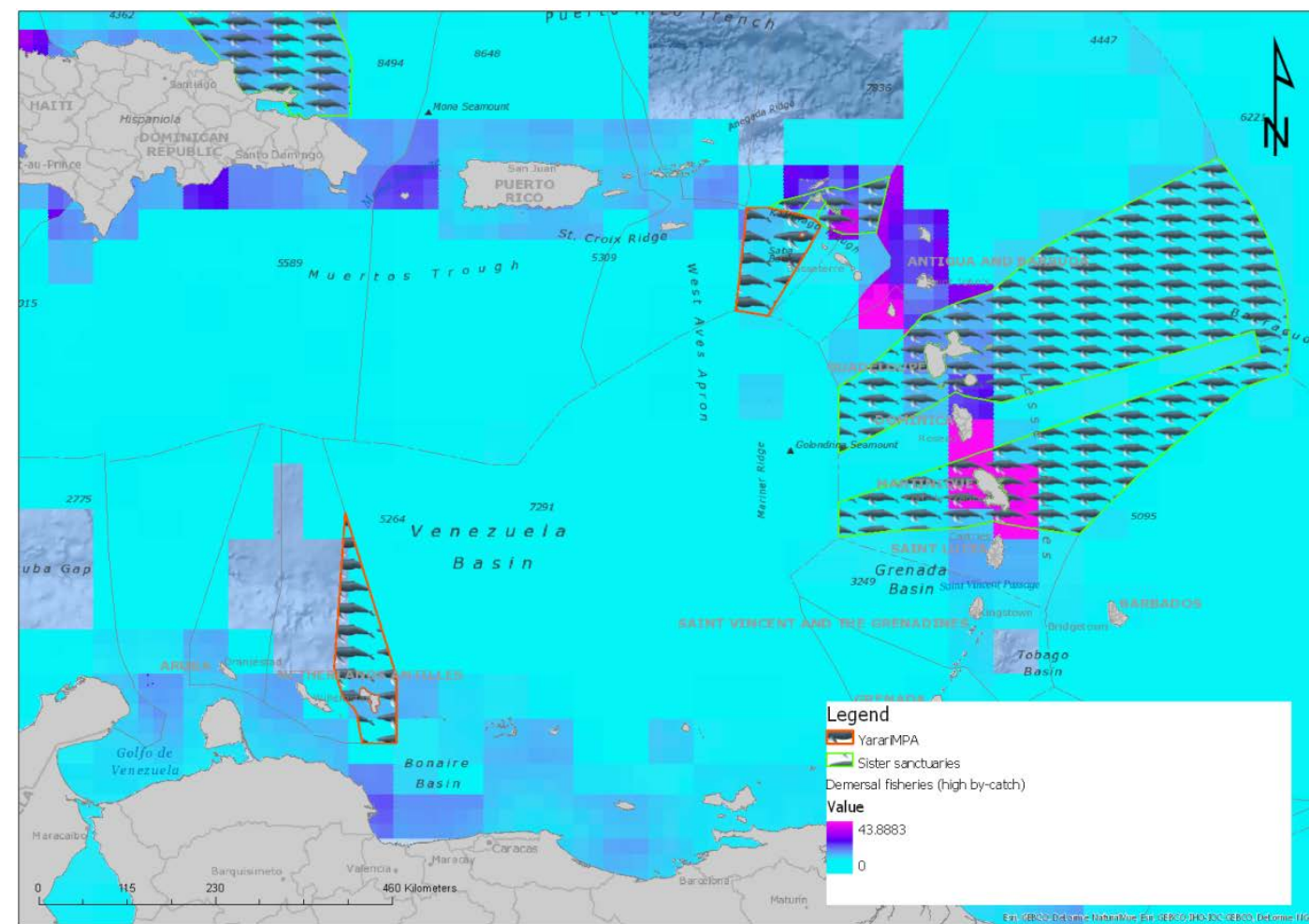

Figure 18 Demersal fisheries / high by-catch (source: Halpern et al. 2015).

\section{Entanglement \& bycatch}

Entanglement and bycatch are likely the main cause for human induced mortality of marine mammals word-wide, however data on the exact scope is still lacking (e.g. Reeves et al. 2013). Entanglement is defined as cetaceans becoming tangled in fishing gear. If animals do not drown they are often seen towing the gear along with them. In contrast, bycatch usually refers to the unintentional capture of cetaceans in fishing nets. Most of the time (with exceptions) entanglements are occurring with large cetaceans and bycatch with small cetaceans. In general, bycatch causes direct death through drowning while entanglement in fishing gear is not necessarily lethal. Almost any type of fishery can cause entanglement or bycatch, but some fishery activities are more problematic than others. Lobster 
pots or similar gear can cause entanglements, which is one of the largest cause of mortality in large baleen whales (van der Hoop et al. 2013). Stationary set-net gear, such as a gill net, is responsible for the highest human induced cause of mortality for small cetaceans. Other types of fishery can also have a high incidental catch of dolphins.

For Caribbean waters there are several records of entanglements of large whales. One example is a report from Guadeloupe, French West Indies from 2013, where a sperm whale calf was entangled in nets by its tail fluke peduncle, while a mature female was entangled with her lower jaw in the same net. The calf was dead and the female was able to forage, with the net and calf attached to her (Rinaldi and Rinaldi 2014). The authors suggest that the entanglement occurred at a local FAD (fish aggregation device). A recent case of entanglement in the Dutch Caribbean involving the death of two sperm whales has been documented (Luksenburg 2013) (Figure 16). However, the occurrence of entanglement has not often been recorded as a possible cause of mortality in stranded animals of the Dutch Caribbean (Debrot et al. 2011a).

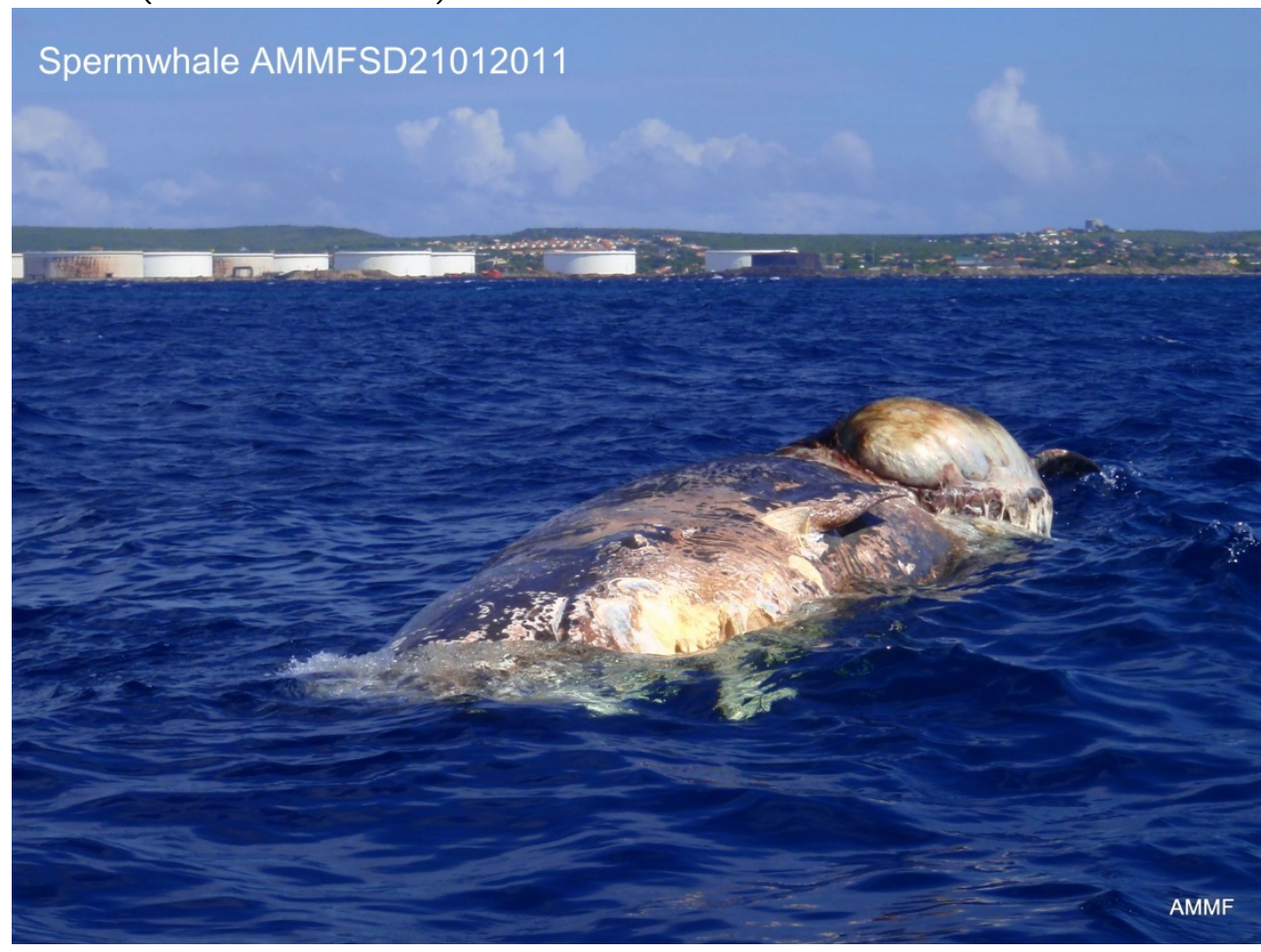

Figure 9 Entangled dead sperm whale floating off San Nicolas, Aruba. Photo: Dutch Caribbean Coast Guard.

Trap fishery is considered a low impact method for small cetaceans (and is often advised as an alternative method for gillnetting). Nevertheless entanglements can occur, such as the case of a bottlenose dolphin that died in 2008 in fishing gear (a rope with 2 pots) from a local fisherman from Cabo Rojo, Puerto Rico (NMFS 2011). For large whales, such as humpback whales, entanglement in trap gear is a well-documented cause of death or injury that can have a high impact on populations (e.g. Robbins et al. 2007, Saez et al. 2013; Pace et al. 2014; Cassoff et al. 2011; Knowlton et al. 2012).

One other potential problem is that shipping (e.g. tankers) can accidentally cut lines of fishing traps or other gear, creating "ghost traps" that continue to collect fish (Sybesma et. al. 1993) and could become an entanglement risk for cetaceans. Fortunately at present the only area with traps that are vulnerable to shipping is the Saba Bank, which is designated as an PSSA (Particularly Sensitive Sea Area) area by IMO and off limits to shipping. Environmental infractions have declined greatly (to only 16 incidents in 2015) since the Coast Guard has sharpened its surveillance protocols for the Saba bank (DCCG 2016). Helpful may also have been the fact that the Coast guard sent neighbouring islands information on the legal status of the Saba bank in the English language. A problem remains that the current legislation only allows persecution of the captain but not the shipping company. According to the DCCG the legislator has not yet been willing to make the necessary adjustments to the law to make this possible (DCCG 2016). 
The Saban fishery is an off-shore artisanal trap-fishery, targeting lobster and snapper ("redfish"). Pots are not individually placed but connected by lines running along the bottom. In addition, hook and line fishing with hand-lines or with rod and reel is done opportunistically. Fish Aggregating Devices (FADs) are also deployed by some Saban fishers to increase catch rates for pelagic species such as wahoo, tuna, and dolphinfish (Lindop et al. 2015). Similarly, the St Eustatius fishery is also small-scale using traps, hook and line trolling and occasionally nets. The low number of pot set lines and low cetacean densities mean that numerical mortalities are likely low. Nevertheless, if population densities are also low, even low number of mortalities may translate to a high death rate.

Outside of the Dutch Caribbean EEZ longline fisheries for swordfish take place and purse seine fisheries for tuna, particularly by Venezuela, and in the southern sector of the Caribbean. In Atlantic tropical and subtropical waters it is particularly killer whales (Orcinus orca) and false killer-whales (Pseudorca crassidens) that are known to be attracted to long-lines as an easy food source (Hernandez-Milian et al. 2008), and pilot whales (Globicephala macrorhynchus) (Hamer et al. 2015). These are the most common species reported as by-catch from tropical longlines. In the Atlantic, the percentage of longline sets predated is comparatively low, ranging between 1 and 9\% (HernandezMilian 2008). Less than $0.7 \%$ of the catch in the US Atlantic swordfish longline fishery concerns turtles, mammals or birds (Mandelman et al. 2008). In this fishery various restrictions have been imposed in recent years to restrict bycatch of cetaceans and other non-target species (Mandelman et al. 2008). One of these is the use of circle hooks instead of J-style hooks (Kerstetter and Graves 2006). Hamer et al (2015) discuss innovative gear modifications that can further restrict cetacean bycatch.

Venezuela is the most important fishing nation in the eastern Caribbean. Between 1995 and 2014 its motorised fleet size has doubled to more than 20 thousand vessels but its total annual catches have roughly halved during the same period (FAO 2016). In 2014 its total annual catch was reported to be 225 thousand tons whereas most other Caribbean island nations have total annual catches below 10 thousand tons (FAO 2016). Most of these are small coastal fishing vessels. Coastal bycatch of small cetaceans in gillnet fisheries is likely but undocumented. Particularly important is the offshore small vessel pelagic longline fleet targeting dolphinfish, bilfish, sharks and tuna (Arocha et al. 2013). It also has an important distant water fleet.

Venezuela is reported to conduct whale-associated purse seine sets for tuna year-round in the Caribbean (Gaertner \& Medina-Gaertner 1999 cited in Escalle et al. 2015). Whale-associated tuna sets in the eastern tropical Atlantic are the norm, in contrast to the eastern tropical Pacific where dolphinassociated sets predominate (Escalle et al. 2015). Off Curaçao and Bonaire, in the southern Caribbean, baleen whales and not dolphins are typically associated with tuna schools (Debrot, pers. observ.), see Figure 17. Despite high interaction, cetacean mortalities associated with tuna purse seines in the eastern tropical Atlantic appear quite low (Escalle et al. 2015). For instance, of the 194 cetaceans encircled in a purse seine net ( 122 baleen whales, 72 delphinids), immediate apparent survival rates were high (Atlantic: $92 \%$, Indian: 100\%). These high survival rates suggest that setting nets close to cetaceans has a low immediate apparent impact on the species involved. Fortunately, purse seine-associated kills in the Pacific have declined by $98 \%$ since the 1960 s and 70 s (Escalle et al. 2015). 


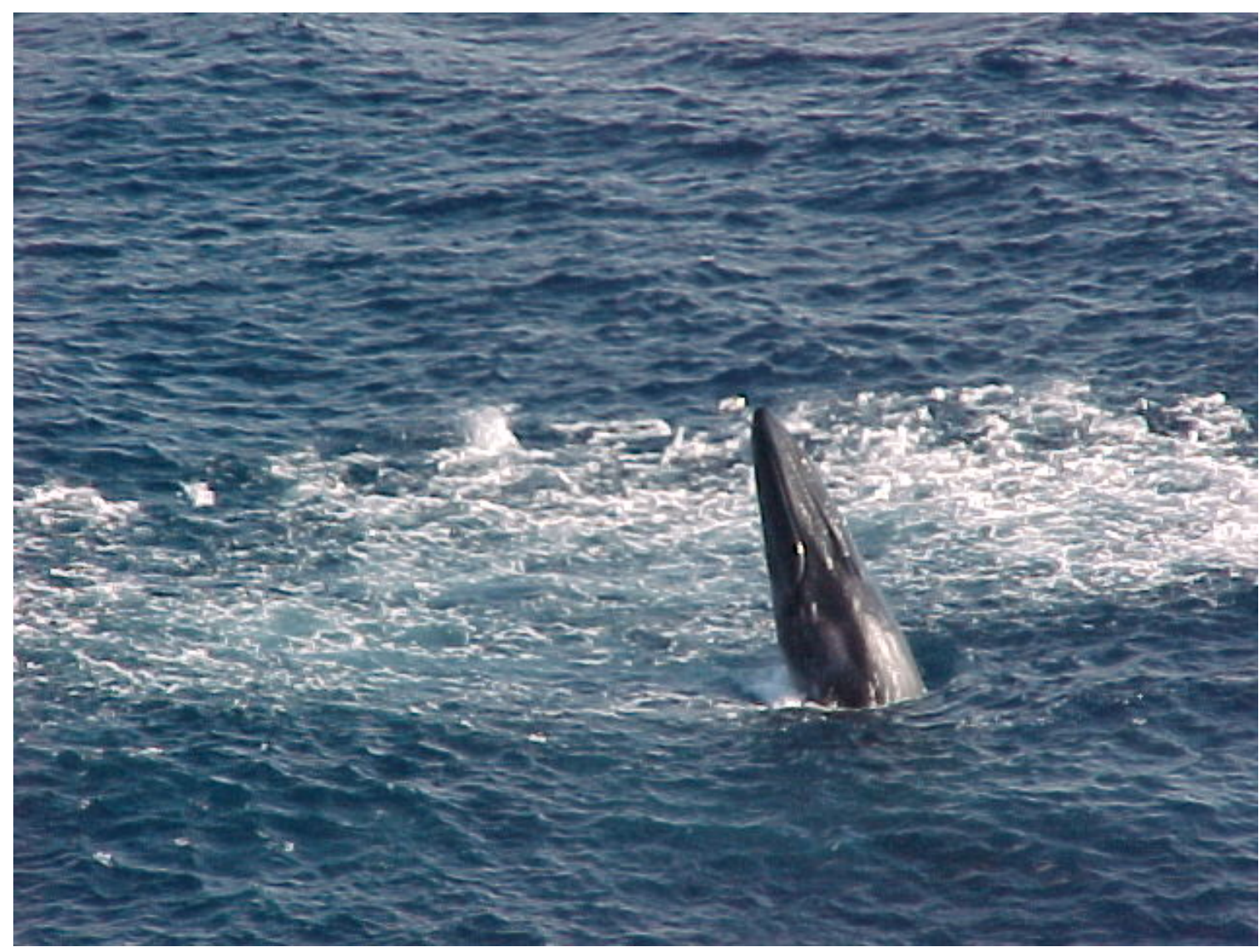

Figure 10 Whale-tuna association (B. edeni) as is typical of the Caribbean (contra Central Tropical Pacific). Off Curaçao November 2001 (Photo: H. Goilo).

Aside from in the southern Caribbean, where there is a large artisanal offshore longline fleet for which cetacean bycatch is poorly documented, in most other areas of the eastern Caribbean intensive fishery activity of risk to cetaceans is low compared to other more productive areas of the Atlantic.

Nevertheless, for the Venezuelan fisheries, also the largest of the eastern Caribbean cetacean mortalities may be quite high and might impact cetacean populations throughout the region. The matter of cetacean mortalities in Venezuela is a sensitive issue and environmentalists exposing such practices have had to hide and seek foreign asylum to avoid persecution and imprisonment in Venezuela (Anonymous 1995).

In the Dutch EEZ currently no significant longline, purse seine, drift or gillnet fisheries occur. With low fishing activity and concomitant low gear densities (only 10 artisanal trap fishing boats in a 2000-km² area), risk to cetaceans will also likely be low. This means that current legislation could be easily upgraded to exclude high-risk gillnet use and to impose long-line gear restrictions or measures (such as hook type) to limit cetacean bycatch prior to any actual development of a pelagic longline fishery for dolphinfish, should it ever be considered. Long-line fisheries in the Caribbean take significant large bycatches of endangered sharks and ICCAT-restricted tuna species (Weidner et al. 2001, Cortes 2002, Grant and Berkes 2007, Mandelmann et al. 2008, Arocha et al. 2013).

To assess the actual impact of fishery entanglement or bycatch on a population, one needs to know the occurrence of bycatch and the population size of the species of concern. In the Wider Caribbean, neither of these are well known. Consequently, the magnitude of the threat to cetacean populations due to fishery operations is difficult to assess. In the marine mammal action plan developed by the Caribbean regional seas program of the United Nations Environment Programme (UNEP) it has been suggested that local scientists and UNEP's RAC/SPAW officials develop regional networks, collaborative studies, and training activities to also understand and document the impacts of fishery bycatch and directed catch on cetacean populations in the Wider Caribbean.

For the Yarari Sanctuary, no reports of interaction between fishery and cetaceans are known, this includes anecdotal historic sources. Even though Yarari has low levels of fishing activity, it remains 
surrounded by areas with much higher fishing activity. Consequently, fishing induced mortality from outside the sanctuary may still be a significant threat to Yarari cetaceans. In conclusion, the current lack of data does not imply that there isn't a potential problem, however, given the small scale of the fishing activity, any impact on the cetaceans stemming from fishing inside the Yarari Sanctuary is likely to be very small. The impacts of fishing outside the sanctuary, in the greater Caribbean, may be high but are currently poorly documented.

Data needs (mainly relevant within the context of the Wider Caribbean region) are:

- Compile data on the type, scope and location of fishery activities in the greater Caribbean

- Necropsies to determine the cause of death of stranded animals

- Photo-identification work to document entanglements

- Distribution of cetaceans in the area to highlight potential areas of overlap and conflict.

\section{Directed hunt}

A number of Caribbean islands at times hunt, or use bycaught or stranded small cetaceans like dolphins, porpoises, orcas, and short-finned pilot whales for human consumption (e.g. Caldwell and Caldwell 1975, Hoyt and Hvenegaard 2002, Mohammed et al. 2003, Vail 2005). The scale and implications of these unregulated hunts on the local populations are not known (e.g. Romero and West 2005). Marine mammal densities in the Caribbean, especially of the large whales that were formerly commercially targeted, are certainly manifold lower than in former times and are now slowly recovering from former overexploitation (Meesters et al. 2010).

A live-capture fishery for bottlenose dolphins (for display in dolphinaria) has been documented in Cuba, Dominican Republic, Haiti and Honduras (van Waerebeek et al. 2006; Parsons et al. 2010). The only Caribbean nation currently conducting a directed hunt of large whales is St Vincent and the Grenadines. The IWC is setting aboriginal catch quotas (known as strike limits) in six year blocks. The current quotas will be reviewed at the IWC Commission Meeting in 2018. The quota for humpback whales for the seasons 2013 - 2018 for St Vincent and the Grenadines is no more than a total of 24 humpback whales (https://iwc.int/aboriginal). While the Scientific Committee of the IWC repeated its advice that this block catch limit will not harm the stock, it also expressed concern that there is no officially agreed abundance estimate for this stock. Recent work by Stevick et al. (2014) suggests that the humpback whales of the south-eastern Caribbean may represent a distinct migratory unit. This once abundant "sub-population" was historically severely hunted and is the most depressed of the apparent two Caribbean migratory groups.

Humpback whales occurring in the Caribbean area migrate to Arctic feeding grounds in the summer months. There is no directed hunt or culling of cetaceans or use of bycaught or stranded cetaceans for consumption in the area of the Yarari Sanctuary. There is a low-scale aboriginal hunt for humpback whales in Greenlandic waters which might target the same animals that are spending the winter months in the Yarari Sanctuary. As long as the data on humpback whale subpopulations in the Caribbean are lacking it is difficult to determine if any hunt, either in the feeding or breeding grounds, could have a detrimental effect on the population.

\section{Data needs:}

- Determine the occurrence of humpback whales (distribution, density, movements) in the Yarari Sanctuary and beyond;

- Conduct photo-identification and genetic studies on humpback whales in Yarari to determine their migratory routes \& feeding areas;

- Investigate the use of (small) cetaceans used for human consumption as bycatch or in unregulated hunts in the Wider Caribbean region ("marine bushmeat"). This is, however, mainly relevant within the context of the Wider Caribbean region.

\section{Overfishing (indirect effects)}

In cases where cetaceans and the fishing industry target similar prey, food competition may be a problem. In some areas of the world overfishing, in particularly on larger predatory fish, has dramatically changed the marine ecosystems (e.g. Myers and Worm 2003). Changes in the availability of prey can cause cetaceans to change their distribution (e.g. Nøttestad et al. 2015). Nevertheless 
Ruzicka et al. (2013) point out that the actual food conflict between man and cetaceans is relatively limited and would remain so even if cetacean populations were to increase 5 fold. Food competition between man and cetaceans (in a general sense) would first become problematic in the case of odontocetes as they tend to target species higher in the food web which are also often sought by man (Ruzicka et al. 2013). For some of the probably resident cetacean populations, like the bottlenose dolphins, a reduction in local prey could be relevant, if there is an overlap in prey species with fishery. Due to the low fishery activity in the Yarari Sanctuary we would expect this not to be a problem, but it cannot be considered certain with the currently available data.

Baleen whales typically target small schooling fish species. These have been reviewed by Couperus et al. (2014). Small schooling species are only importantly targeted by human in the leeward Dutch Caribbean but not in the windward islands. Most fishery activities in the Dutch Caribbean target reef fishes using hand lines or lobster pots, or large migratory pelagic species using hand lines (Dilrosun 2000, 2007, van Buurt 2001). The impact of these fisheries on food availability for cetaceans is likely very limited, primarily because of the small and artisanal nature of the local fisheries that represent a low total annual catch (van Buurt 2001; FAO 2016). For instance, baleen whales (with the exception of the humpback whale that does not feed in the area) in the Dutch Caribbean are typically associated with schools of engraulid and clupeid baitfish, which are practically only targeted by man as baitfish for large pelagics or for the Seaquarium (Couperus et al. 2014).

\section{Data needs:}

- Determine the occurrence of fisheries (type, location, intensity and species taken);

- Determine the occurrence of cetaceans (species, location, density, prey species).

\subsubsection{Noise pollution}

\section{Marine mammal sound production and noise}

The impact of sound on marine fauna will depend on the physical aspects of the sound and the biological properties of the species of concern. For the physical aspects a range of parameters are to be considered (type of sound, sound level, frequency bandwidth, the propagation loss as a function of bottom contours, temperature and salinity). As the Yarari north and south areas have different bottom contours it will be clear that the propagation of noise will have different trends in both regions.

Cetaceans rely on acoustics for spatial orientation, communication, mate attraction, foraging and predator avoidance (Richardson et al., 1995). They produce species specific vocalisations consisting of echo-location clicks and social related calls. Echo-location clicks are pulsed sounds of high intensity and frequency of short duration. The animal has the ability to adapt the sound characteristics (frequency, click interval, source level, pulse duration, etc.) to the conditions of background noise, distance to the target and characteristics of the target to obtain a most efficient performance (Richardson et al., 1995).

Marine mammal sounds may be interfered with or masked by anthropogenic noise and the characteristics of the noise may have an impact on the auditory senses and behavior of the animal. The responses may vary greatly - ranging from changes in behaviour, to displacement, an increase in stress or even to death - depending on the type, intensity and frequency of sound as well as the individual cetacean exposed (e.g. species, age, sex) (e.g. Weilgart 2007). Southall et al. (2007) proposed exposure references for each auditory impact gradient and sorted marine mammals in categories of their frequency ranges, i.e. in low, mid and high frequency classes. The mid-frequency category proposed functional hearing range was based on an assessment 32 species and subspecies of "dolphins," six species of larger toothed whales, and 19 species of beaked and bottlenose whales. "Functional" hearing in this group was estimated to occur at approximately $150 \mathrm{~Hz}$ and $160 \mathrm{kHz}$. For the Caribbean the low and mid frequency categories are relevant. Low frequency baleen and toothed whale species occurring in the Caribbean produce vocalisations in the range of $10 \mathrm{~Hz}$ to 31 $\mathrm{kHz}$ (Richardson et al., 1995). Dolphin species of the mid-frequency range occurring in the Caribbean produce vocalisations within $150 \mathrm{~Hz}$ to $160 \mathrm{kHz}$ (Southall et al., 2007). In addition, impact gradients were defined for the two basic temporal structures continuous and impulsive noise/sound. For each of these gradients a reference threshold level was proposed to enable risk assessment per species and 
sound type. Au et al. (2006) measured the vocalisations of a humpback in close range and reported varying Source Levels for units of a humpback song between 151 and $173 \mathrm{~dB}$ re $1 \mathrm{~Pa}^{2} \mathrm{~m}^{2}$. Highfrequency harmonics extended beyond $24 \mathrm{kHz}$, suggesting that humpback whales may have an upper frequency limit of hearing as high as $24 \mathrm{kHz}$. Andre and Kamminga (2000) suggested that click sequences of sperm whales and dolphins present the identification code of individuals in its group and allows the groups to coordinate foraging activities. Wright \& Walsh (2010) suggested that humpback songs communicate male fitness to female whales. The first results of a Maru recorder deployed at the north eastern shelf-edge of Saba bank showed multiple vocalisations of Humpback whales, Minke whale and fish. From February to April humpback whale song was recorded on more than $89 \%$ of all recording days. Minke whale click trains were detected less frequently (Risch and de Haan, 2016) and are known to produce low-frequency pulse patterns in the range of 58 to $160 \mathrm{~Hz}$ (Risch et al. 2013).

The impact of anthropogenic noise may depend on the level and temporal changes against those of the vocalising marine mammal species. Both the interfering noise and vocalising marine mammals consist of impulsive and continuous temporal structures. The actual impact of anthropogenic noise on marine mammals highly depends on the nature of the sound and on the presence of a marine mammal in a certain area and the latter is often hard to explain or predict (Richardson et al. 1995). Information on the magnitude, sound frequency and position of anthropogenic noise sources against the positions and monitored behaviour of marine mammal is needed to enable impact assessment. For this purpose, long-term acoustic monitoring will be needed.

\section{Antropogenic noise in the Wider Caribbean}

The underwater background noise signature in the Yarari area will be a composition of natural ambient primary sources of wind and rain. These figures may not be as variable as in European waters, but a result of winds mainly from the east with average forces between 3 and $6 \mathrm{Bft}$, with incidental higher peaks of hurricanes in the autumn months. The spatial abundance of anthropogenic noise sources has the highest density in the vicinity of the Caribbean islands and will consist of a mixture of continuous type of noise and more incidental base impulsive type of noise generated by seismic instruments (airguns and sparkers), naval sonars and fish detection systems.

A broad impression of the overall background noise composition including noise sources can be achieved by using Wenz curves (Wenz 1962). The example based on Wenz curves shows the result of a broad spectrum of natural "ambient" noise referred as sea-state categories and anthropogenic noise sources (figure 18). 


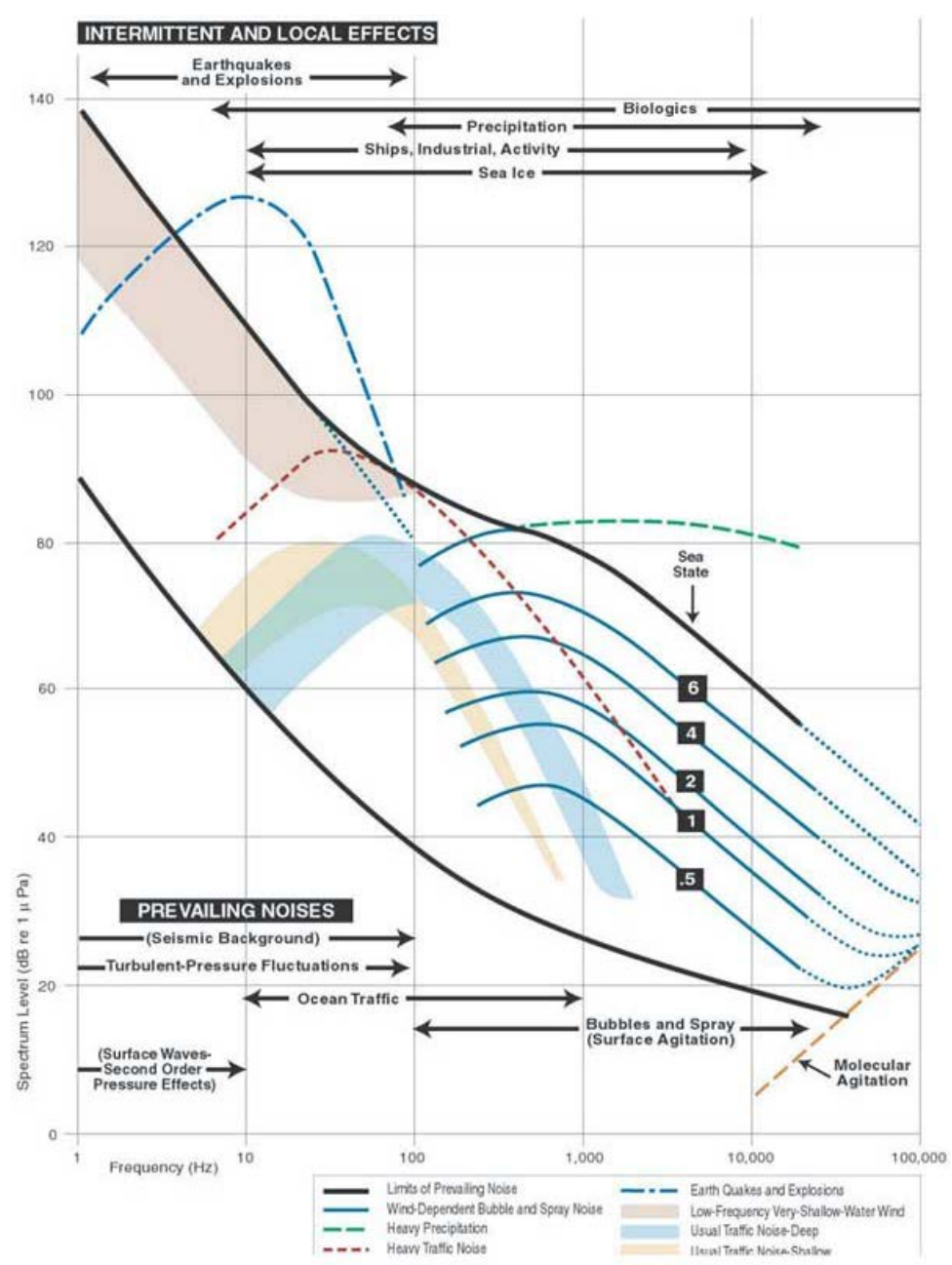

Figure 11 Composition of noise spectra of natural conditions in terms of sea-state and contribution of individual components to the overall noise spectra (Wenz 1962).

Shipping is a major contributor to anthropogenic noise given their large number, mobility and wide distribution and may have the most aversive effects on marine mammals (Richardson et al., 1995) and this will also be valid for the coastal zones of both Yarari areas. Other noise sources, which may cause significant impact are naval exercises with operations of low-frequency sonars and impulsive noise exposures of seismic research (University of Texas) as conducted off the coast of Bonaire in 2015.

\section{Shipping noise}

As shown in a spatial model for shipping intensity (Halpern et al. 2008) shipping in the Wider Caribbean is one of the main anthropogenic impact drivers with highest contribution along the shipping lanes of the Caribbean Isles. The shipping intensity map mainly consists of contributions of industrial liners and ferries with fixed cycles of repetition in a fixed lane, mainly between the interisland lanes. An indication of the shipping traffic intensity in and around the Yarari Sanctuary is presented in Figure 19.

Leisure crafts are less fixed in temporal and spatial structure and may also produce higher frequency noise, such as produced by hydro jet driven propulsion systems. Last but not least the sound level production will depend on the maintenance of gearboxes which may add to pure tonal sounds when gear boxes are of lower quality or maintenance. The effects of disturbance by the presence of tourist boats was clearly shown in the behaviour of Indo-pacific bottlenose dolphins (Tursiops aduncus) off the coast of Zanzibar (Christiansen et al. 2010). The research showed that foraging, resting and socialising all decreased as an effect of tourist boat presence, while travelling increased. The behavioural responses are likely to have energetic implications, mainly by increasing physical demands. Further, the results demonstrate that the current level of tourism intensity off the south 
coast of Zanzibar affects the dolphins' cumulative behavioural budget. Regulations on dolphin tourism were urgently recommended to minimise potential long-term negative effects on the dolphins.

Au \& Perryman (1982), Janik and Thompson (1996), Constantine \& Baker (1997), Nowacek et al. (2001), Van Parijs \& Corkeron (2001), Lusseau (2003), Bejder et al. (2006), Stensland and Berggren (2007) confirmed disturbances by showing various behavioural changes in dolphins including changes in activity, speed, movement, diving behaviour, group formation and vocalisation. Bejder et al. (2006) suggested that some of these impacts may be long-term and life-threatening, both at the individual and population level.

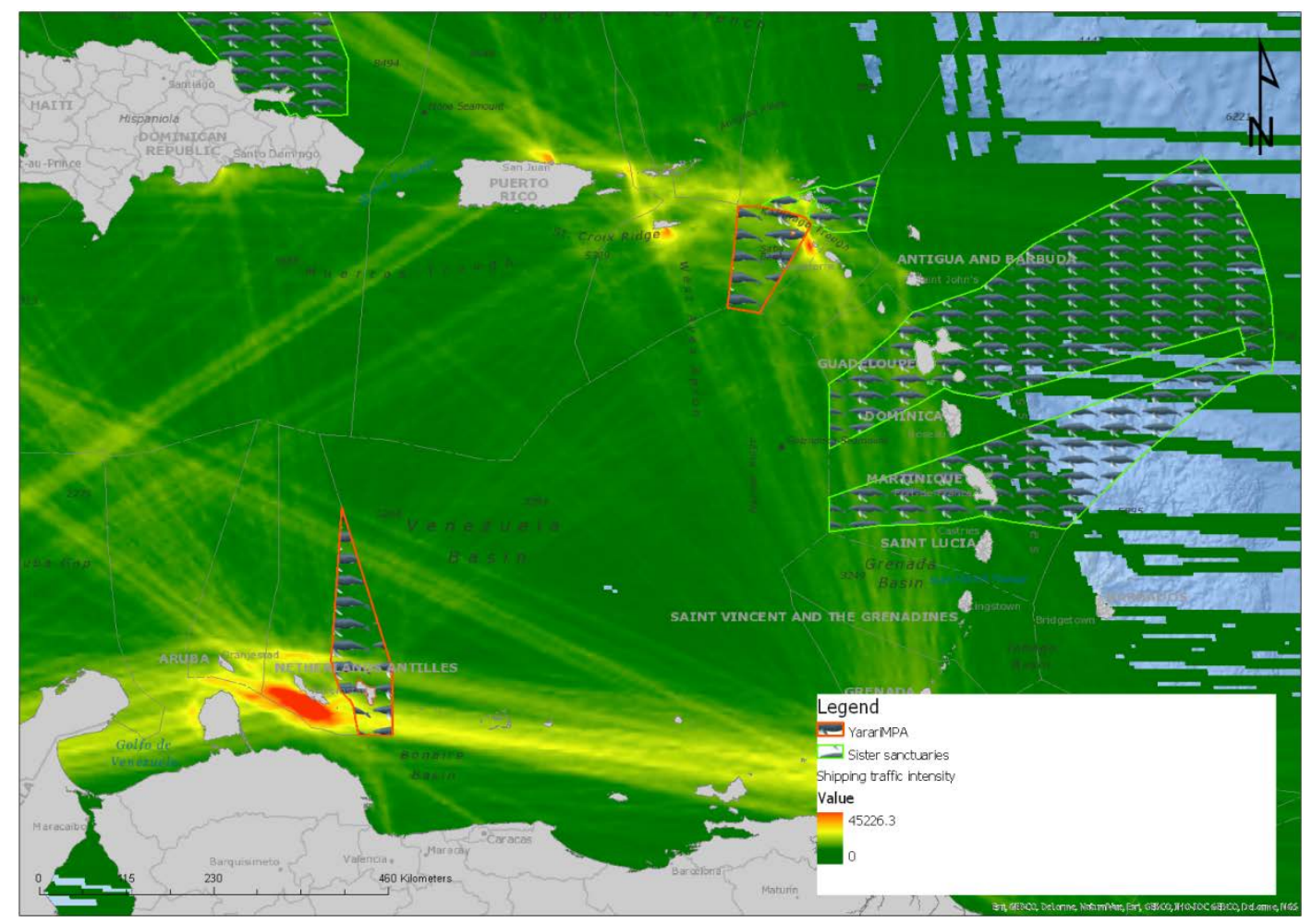

Figure 12 Shipping traffic intensity (source: Halpern et al. 2015).

\section{Naval sonar surveys}

Shipping operations may involve continuous noise of high-speed propulsion and impulsive noise of low-frequency sonar systems of very high sound pressure. Military sonar transmissions were sometimes correlated, in specific conditions, with mass stranding events of (predominantly) several beaked whale species, including Cuvier's (Ziphius cavirostris), Blainville's (Mesoplodon densirostris), and Gervais' (Mesoplodon europaeus) beaked whales (in Southall et al., 2007, see Evans \& England, 2001; Fernández et al., 2005; Cox et al., 2006). Ainslie et al. (2009) reported for a range of LF Dutch navy sonars sound pressure levels of 217 to $227 \mathrm{~dB}$ re $1 \mu \mathrm{Pa}^{2} \mathrm{~m}^{2}$. On the operation of LF sonars recent mitigation measures were developed to exclude the possibility of odontocetes inside the exposed area prior to operation. Characteristics of military sonars are sparse and rarely published. Watkins et al., 1985 sperm whale behaviour in the southeast Caribbean and described a submarine sonar signal modulated between 3.25 and $8.4 \mathrm{kHz}$ in pulses of 0.145 to $0.45 \mathrm{~s}$ period, fired in sequences of 4 to 20 pulses. Van Bree and Kristensen (1974) were the first to suggest that naval exercise-related marine noise might be a cause of mortality of cetaceans in the Dutch Caribbean while Mann et al. (2010) appear to have determined an instance of hearing loss as a potential cause of stranding of a pilot whale in Curaçao.

\section{Seismic surveys}

Seismic surveys do occur around the Caribbean isles, with a most recent example being the survey conducted by the Texas university in November 2014 in the coastal waters around Bonaire. In this example 4 areas off the Bonaire coast were surveyed using a sparker seismic instrument with 700 J oule output. Questions arose on the permits of such a survey and if the rules in the Dutch North Sea 
EEZ are also applicable in the EEZ of Dutch Caribbean waters. When executed within the $12 \mathrm{Nmi}$ boundaries these surveys require a permit under the Dutch Maritime Management Act, which is administered by the ministry $I \& M$, but permit requests are evaluated in cooperation with my ministry (EZ) for advice on any impacts on biodiversity. Given the local coastal conditions with steep bottom slopes impulsive sounds could have impact over much longer distance than the presently defined exclusion zone of $100 \mathrm{~m}$ and noise measurements during a seismic survey are recommended.

\section{Al S (Automatic I dentification System) detections}

To weigh the impact of noise against the received position of vocalisations temporal information on shipping activities is a standard requirement for acoustic assessment. AIS raw data records will provide this information with momentary positions of vessels provided AIS transponders are installed (industrial vessels, ferries, liners and tankers). Shipping activity around the windward and leeward isles are tracked by AIS and Radar stations and facilitated by the Dutch Coastguard and data managed in The Netherlands by Saab Technologies BV. The current status is that AIS for windward isles depend on a single AIS station installed on top of Mnt Scenery, Saba, which has a detection range of approximately $160 \mathrm{~km}$ and fully covers windward Yarari. Leeward isles are provided with AIS and radar stations and have a detection range of respectively 140 and $50 \mathrm{~km}$. As the most northern point of leeward Yarari is at $250 \mathrm{~km}$ distance from shore shipping activity in a significant area of leeward Yarari will not be detected and additional measures are required. AIS data of leeward Yarari are fused with radar data up to an estimated range of $50 \mathrm{~km}$ from leeward shores. As radar stations are not installed on windward isles fishing vessels and leisure crafts not equipped with AIS transponders will not be detected in windward Yarari. Shipping activity outside these boundaries will not be detected. An example of a 24 hour AIS data record made of Mnt Scenery (Figure 13) as example for the assessment of acoustic monitoring around Saba Bank in the winter of 2015/2016.

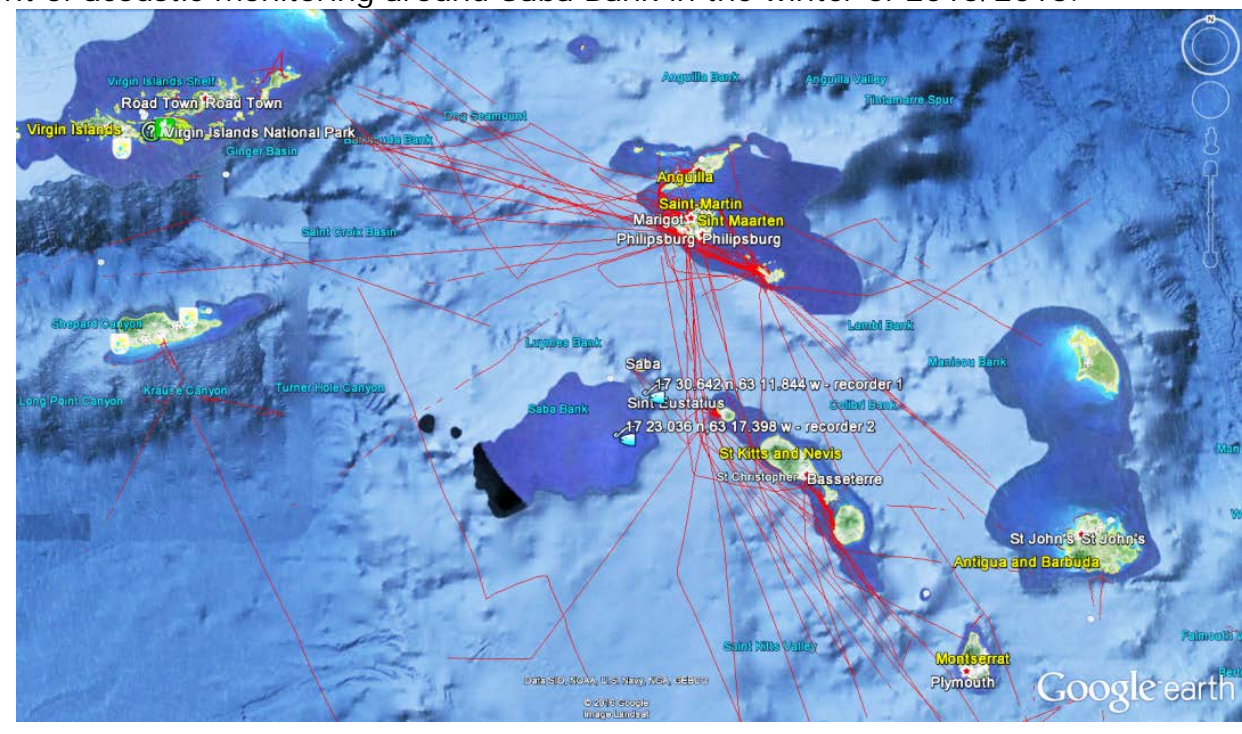

Figure 13 Example of 24 hours shipping (all categories) in the fall of 2015 taken from the raw AIS data from the Mnt Scenery AIS station.

\section{Acoustic noise measurements}

Considering the amount of ship traffic moving through the northern sector of the Yarari Sanctuary, particularly the large number of large tankers visiting the island of St. Eustatius right adjacent to the sanctuary, noise pollution is certainly a factor to assess and follow. In many cases long-term background noise results are lacking calibration. A first step forward was made with background noise estimates from the records of a Marine Autonomous Recording Unit (MARU) pop-up logger deployed in the winter of 2011/2012 (Risch and de Haan 2016). The median sound pressure levels of background noise in the 10 to $1000 \mathrm{~Hz}$ 1/3 octave band peaked at $400 \mathrm{~Hz}$ with variations between 75 and $95 \mathrm{~dB}$ re $1 \mu \mathrm{Pa}$, indicating the contribution of vessel noise. Long-term background noise measurements were continued in the winter of 2015/2016 with the deployment of two AMAR-G3 recorders on two positions around Saba bank. In this configuration the bandwidth was increased from $8 \mathrm{kHz}$ to $24 \mathrm{kHz}$ to include vocalisations of dolphin species. 


\section{Data needs:}

- Human activities in the Yarari Sanctuary and adjacent regions and the sounds they produce (e.g. shipping, military exercises, seismic exploration).

- Distribution (seasonal) maps of cetaceans in the Yarari Sanctuary to detect potential conflict

- If there is a potential problem, investigate mitigation options (e.g. regulations on timing and scope of sound production)

\subsubsection{Collision}

In most (reported) cases collisions between whales and vessels involve large whales, but all species can be affected. Large whales are often transported on the bulbous bow of large vessels and are only noted when the ship enters port. The cetaceans that are hit can be either injured or killed. Damage to the vessels has also been reported, as well as serious injury and fatalities to passengers. To quantify the occurrence of ship strikes one can use direct observations from vessels as well as the pathological examination of whale carcasses found floating at sea or stranded.

A joint IWC (International Whaling Commission) and SPAW/UNEP Workshop to address collisions between marine mammals and with a focus on the Wider Caribbean, was held in Gamboa (Panama, 18-20 J une 2014). The resulting report (IWC 2014) reviewed current, relevant ship strike mitigation measures with experts from around the world, identified data gaps and information needs in the region, discussed management initiatives which are most likely to be effective in the region, and beyond, and recommended concrete actions for the IWC, UNEP-SPAW and member countries. The workshop reported that there are few (around 10) reports from the Wider Caribbean area listed in the IWC Ship Strikes Database from 1961- present (see https://iwc.int/ship-strikes). From 1991 to 2010 four ship strikes have been recorded for the Caribbean region, including Omura's whale ( 1 Nov 2000, 100 km SW Bonaire I sland), Sperm whale (18 January 2001, 20 nm off Puerto Rico), Bryde's whale (11 January 2000, SW of Bonaire) and Pygmy Sperm Whale (30 October 1991, St. Croix I sland, Virgin Islands). Some additional reports exist from Guadaloupe (five strikes) and potentially two further reports from the Dominican Republic. In April 2014 there was a 'near miss' documented by a survey vessel where a near collision of a humpback whale with a high-speed fishing vessel. The Workshop noted that small cetaceans are probably involved in collisions with smaller fishing boats, too, as many of the photographs of small cetaceans taken for photo-identification purposes within the region have propeller scars.

It is likely that the occurrence of ship strikes in the Caribbean region is highly underreported. Nevertheless, high-speed vessels are largely concentrated in the nearshore zone on the lee side of the islands. The species most at risk can be expected to be dolphins. In fact Luksenburg (2014) found high incidences of external injury in small coastal cetaceans in Aruban waters.

Data needs:

- Shipping activities in the area to highlight potential overlap of shipping and cetacean occurrence

- Pathological examination of animals stranded or found drifting at sea

- Photo-identification of animals to document scars from ship strikes (e.g. propeller strikes)

\subsubsection{Marine debris}

Marine debris (also called marine litter) consists of many different types, ranging from glass, metal, plastics and wood to abandoned or lost fishing gear. Because a lot of the litter is synthetic it can stay in the ecosystem for a long time. Marine litter is often split up in macro-debris (generally anything over $5 \mathrm{~mm}$ in size) and micro-debris (under $5 \mathrm{~mm}$ in size). Macro-debris includes abandoned, lost or discarded fishing gear which, while not "active", can still catch cetaceans.

A recent review by Baulch and Perry $(2014 a, b)$ found that ingestion of marine (macro) debris has been documented in 48 cetacean species. The dominant type of debris ingested is plastics (Baulch and 
Perry 2014a; 2014b). For the Dutch Caribbean, ingestion of anthropogenic debris has so far only been documented in two stranded beaked-whale specimens (Debrot et al. 1998, 2011a). There is still uncertainty on the potential scope of lethal and sub-lethal effects. In terms of microplastics, ingestion has now been demonstrated in many marine species, including plankton, fish, and Mediterranean fin whales (e.g. Fossi et al. 2012). The physiological and toxicological effects of microplastic ingestion for cetaceans remain poorly understood. Marine debris from nets or traps can also be cause of entanglement or bycatch for cetaceans.

Data needs:

- Investigation of marine debris occurrence at sea

- Investigation of the occurrence of beached and/or submerged marine debris

- Pathological investigation of cetaceans with regard to marine debris (adjusted protocol)

- Investigation on the compliance with international laws on dumping garbage at sea

Recent surveys of both beached (Debrot et al. 1999, 2013b, c) and submerged marine litter (Nagelkerken et al. 2001, Debrot et al. 2014) highlight that the litter issue is very severe in the Dutch Caribbean. Most litter floats in from elsewhere which stresses the need to address the problem internationally in regional context. Even though the density of litter is unquestionably high compared to many other sea areas, the ingestion of debris by cetaceans may be still be limited and its effect also. Nevertheless, (and not only for marine mammals) it is a priority for the islands is to participate actively in the regional marine litter action plan (UNEP 2008).

\subsubsection{Contaminants}

Contaminants can come from a number of different sources, such as: sewage, industrial discharges, agricultural and mining return flows, atmosphere pollutants, waste from ships (including tank cleaning), oil spills, discharge of ballast water, dumping at sea, and offshore exploration.

Because cetaceans are at the top of the marine food chain, they have long life spans and because of their long biological half-time of eliminating pollutants they can accumulate high levels of most type of contaminants (e.g. Salata et al. 1995). This is also the case in the eastern Caribbean (Gaskin et al. 1974). The range and number of contaminants in the marine environment that could potentially harm cetaceans is too large to address here. However, we highlight a few components that could be of particular importance.

Polycyclic aromatic hydrocarbons (PAHs) are primarily found in combustion products like oil and coal, and produced as a by-product of burning. Oil spills could increase the exposure of PAHs in cetacean habitats and populations. Polychlorinated Biphenyls (PCBs) are a persistent contaminant of air, soil and water, that have a very high affinity for fat. They do not break down easily in the environment so although they are no longer produced or used, they still pose a potential health problem for some cetacean species (e.g. Jepson et al. 2016). There is a large body of evidence available that PCBs can impact immunity, thyroid health, skeletal integrity and reproductive hormones. Preliminary analyses suggest very high levels of PCB contamination may be present in reef fish in Curaçao (G. van Buurt, pers. comm. to A. Debrot), and may also represent a problem for human or cetacean consumption of such fish.

Chemicals of Emerging Concern (CECs) include new chemicals that are emerging in marine and coastal environments, such as halogenated flame retardants, perfluorinated compounds, current use pesticides, hormones, pharmaceuticals and nanomaterials (e.g. Yan et al. 2010). Heavy metals such as cadmium, lead, zink, copper, iron, nickel or chromium are known to have toxic effects and to accumulate in cetacean tissues. For many of these components it is difficult to obtain a direct line of evidence between the amount of contaminants found in cetaceans and the effects they might have on their health. However, because cetaceans are at the end of the food chain, chemical pollutants accumulate in their tissues in high concentrations. Several recent studies have found direct effects on reproductive failure due to high contaminant levels (e.g. Murphy et al. 2015).

Some information on oil contamination is available. In both sectors of the Dutch Caribbean there are oil transhipment facilities. On Bonaire various petroleum products are bunkered at BOPEC and on St 
Eustatius at NUSTAR. For instance, there were major oil spills in 2002 (Tanker Paulina) and in 2009 (Tanker Vallombrossa) at St Eustatius. Both of these facilities as well as those on the islands of Curaçao and Aruba generate regular small spills. These islands and shores experience differing levels of chronic and or major spills (Meesters et al. 2010, Klok et al. 2011, Slijkerman et al. 2011). The shores of the Dutch Caribbean islands are variously contaminated with tar (Debrot et al. 1995; Debrot et al. 2013a) and this has a marked effect on rocky shore fauna (Nagelkerken and Debrot 1995).

Nevertheless, in Curaçao the flesh of fish from the vicinity of the harbour of Willemstad smells strongly of petroleum even after cooking (Debrot personal obs.). To what extent the contamination has entered the food chain and is impacting cetaceans in a chronic way remains completely unknown. Because marine mammals have mixed function oxidase enzyme systems necessary for detoxification and elimination of petroleum hydrocarbons, these compounds are not highly accumulated and sequestered in tissues as occurs with chlorinated hydrocarbons (Fair et al. 2010). PAHs were measured in blubber biopsy samples collected from wild bottlenose dolphins during 2003-2005 from two south-eastern US estuarine areas in South Carolina and Florida. PAHs detected in blubber of dolphins were similar to those found in whales in the northwest Atlantic and harbour porpoises from UK waters (Fair et al. 2010).

An indication of the level of pollution in and around the Yarari Sanctuary is presented in Figure 14.

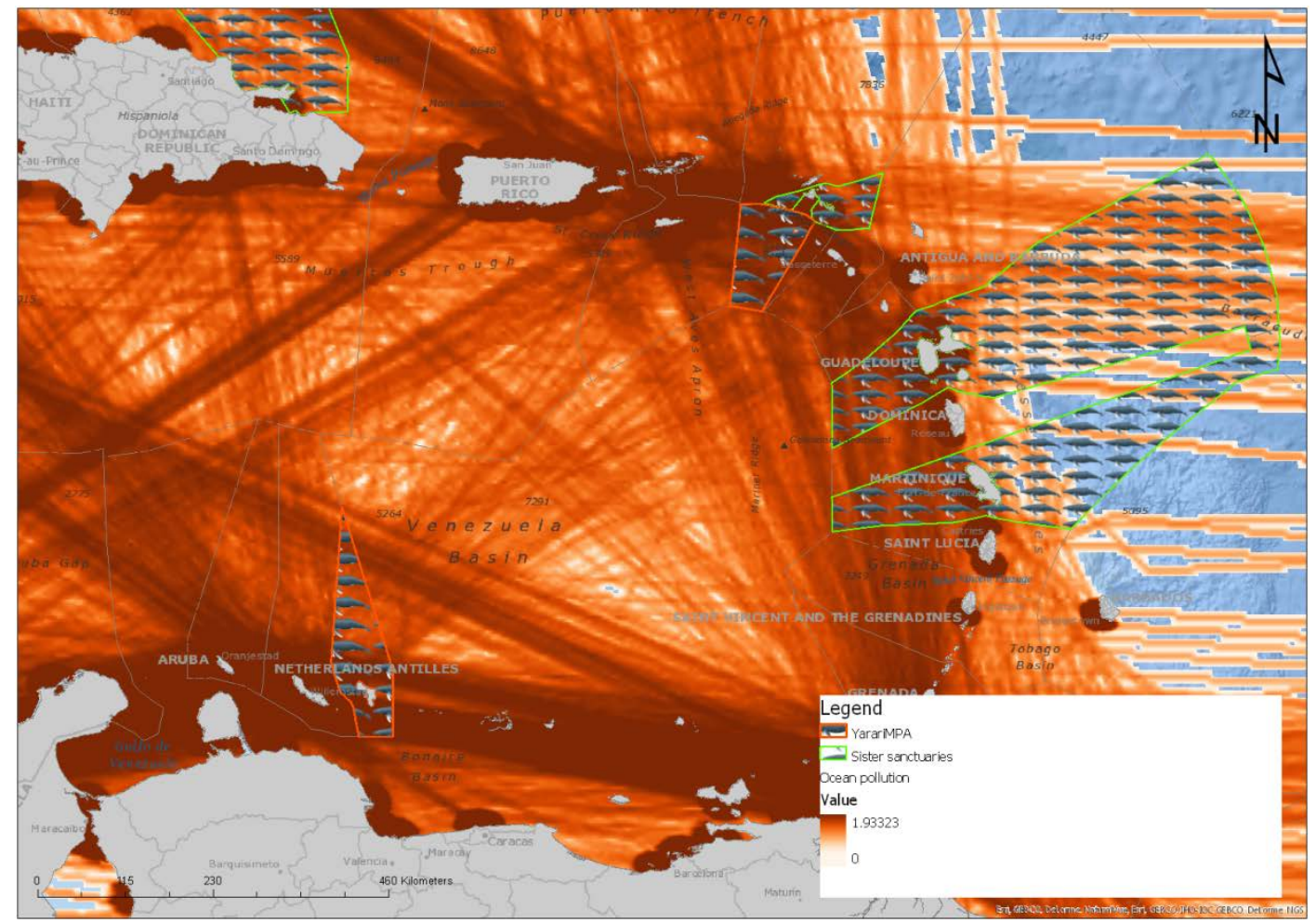

Figure 14 Ocean pollution (source: Halpern et al. 2015).

Data needs:

- Information on the frequency and scope of oil contamination in the waters;

- Information on contaminant levels in the marine ecosystem, including water, plankton, fish and cetaceans;

- Inclusion of contaminant investigations during pathological examination of stranded cetaceans;

- Biopsy sampling of cetaceans to investigate contaminant levels;

- Investigate what kind of risk assessment framework is applicable in case of an oil spill. 


\subsubsection{Habitat degradation}

\section{Marine \& coastal construction}

Most marine mammals present in the Yarari are not common in the nearshore environment. Therefore they are not likely to be strongly affected by the degradation of nearshore habitats. The only exception to this rule would be the West-Indian manatee. Adequate habitat for this species at one time likely existed in both sectors of the Dutch Caribbean but it has been seriously degraded. However, this pertains only to the coastal lagoons and protected bays around St. Maarten, an island which is not yet a participant in the Yarari Sanctuary initiative. Saba, the Saba Bank and St. Eustatius likely never possessed a significant amount of habitat for the manatee.

\section{Anchoring}

Anchoring can cause the destruction of coral reefs, seagrass beds \& other habitat for prey. For instance anchoring by large ships is a recognized problem in St Eustatius (White and Esteban 2007). However, it is not at all clear how this might impact cetaceans.

\subsubsection{Whale \& dolphin watching}

Whale \& dolphin watching most commonly involves observing cetaceans from land, water or air. Whale watching is a fast growing industry in the Caribbean (Vail 2005, Hoyt and Hyenegaard 2002). In some countries there are also touristic activities available which allow people to swim with, touch, or feed wild cetaceans (e.g. Bejder \& Samuels 2006).

Observations from vessels or during flights can have a potential impact on individuals, populations or the habitat of cetaceans. Some potential impacts of designated whale $\&$ dolphin watching include behavioral changes (e.g. increase in speed, changing from resting to travelling), displacement (e.g. leaving a habitat), changes in reproductive success as well as death (e.g. by collision).

Worldwide whale-watching is a large and very successful business globally. The IWC has pulled together the different national guidelines and regulations for whale watching and have formulated this into a "best practice" document (https://iwc. int/wwguidelines). The advice includes limits on vessel numbers, speeds, approach distances and time spent with whales, and a variety of training and permit schemes. A guideline for how to conduct whale and dolphin watching has also been agreed on during the Regional Workshop on Marine Mammal Watching in the Wider Caribbean Region held in Panama City, Panama (19-22 October; UNEP-CEP 2011a, b,c). For the northern Yarari area there are no tour operators at this moment that are only focusing on whales $\&$ dolphins.

Data needs:

- Overview of all tour operators that include whales $\&$ dolphins in their advertisement or program or have had encounters with cetaceans

- Discussion and agreement on guidelines or regulations on how to conduce whale watching

- Training of tour operators that are going to be engaged in whale watching activity

- Monitoring of whale and dolphin populations that are suspect to whale watching activity

\subsubsection{Climate change}

In their review, Debrot and Bugter (2010) conclude that key changes in climate expected this century for the Dutch Caribbean include increases in air and sea surface temperature, an increase in sea level and ocean acidity, an increase in the frequency and intensity of storms and hurricanes general acidification and greater overall unpredictability in weather. The consequences for marine biodiversity are predicted to be far-reaching. The principal effects will likely include further losses to the coral reef systems, erosion of coasts and beaches, increases in various disease vectors, changes in ocean currents, fish recruitment and migration, and a stronger foothold for marine invasive species. The potential impacts on cetaceans were not discussed.

Not surprisingly, the most definitive predictions and available case studies on the climate change impacts on cetaceans are available for arctic and Antarctic settings for which the consequences of 
climate change also appear to be most certain. For tropical settings, predictions are much more difficult. Nevertheless a few hypotheses appear justified.

In tropical areas marine mammals coastal marine mammals will likely have to deal with increased thermal stress, more frequent cases of toxic algal blooms and reduced freshwater flows which will tend to concentrate environmental contaminants from land in coastal and estuarine areas (IWC 2010). Marine mammals already carry high levels of environmental toxicants in their blubber and this may also interact in adverse ways with thermal stress (IWC 2010). To this list of predicted challenges, for the Caribbean we can add the observation that food supplies in the Caribbean are to a large extent result of wind-induced upwelling (Sturm 1991). Any changes to wind patterns or intensity will likely impact food availability and hence impinge upon cetacean population dynamics. Reyer et al. (2015) predict declines in Caribbean fishery potential of between 15 to $50 \%$ but do not discuss potential implications for nature or marine mammals.

For marine mammals faced with large environmental change there are three basic responses at the population level: 1) redistribute to avoid the changes, 2) adapt to changes, 3) go extinct (IWC 2010). IWC (2010) has developed a series of working hypotheses relating to key expected climatic stressors for small cetaceans which dominate the fauna of the Dutch Caribbean.

The working hypotheses from the IWC workshop (2010) are as follows;

- $\quad$ Cetaceans will redistribute to avoid thermal stress

- Changes in ecosystem productivity due to increased thermal stress will cause cetaceans to redistribute based on food needs

- Species in restricted habitats (such as estuarine settings, e.g. manatee) will experience the most severe consequences including health stressors

- Changes in hydrology will have consequences for freshwater and estuarine species

- $\quad$ Freshwater and estuarine species will be most sensitive to sea level rise and habitat for obligate freshwater species will be reduced

- $\quad$ Loss of vulnerable supporting habitat to cetaceans and their prey will impact coastal and estuarine species the most

To this we add:

- Changes in meteorology will disrupt seasonal upwelling (in both intensity and periodicity) and surface currents that are critical determinants of food abundance for all cetacean, whether principally epipelagic or mesopelagic in trophic requirements.

Data needs (mainly relevant within the context of the Wider Caribbean region):

- Sea surface temperature monitoring

- Monitoring of water movement patterns

- Measures of primary productivity

- Monitoring cetacean abundance and migration patterns

\subsubsection{Cumulative effects}

As outlined in the above sections, human activities introduce numerous threats and pressures into the marine environment that can impact cetaceans. It is already very difficult, if not impossible, to determine any direct link between a human activity ("pressure") and its effect on an individual animal or a population. To complicate matters, there is never only one factor to look at - in most cases there are different ones that can influence each other. The relative importance of one pressure can change if the effect is combined with other pressures - meaning it could be more, or less than the sum of the individual pressures. For example, the displacement of animals due to a noise source could be negative locally, but could also lead to the colonization of a new habitat which could have more or less other pressures (e.g. bycatch). Similarly, a high level of contaminants might not lead to a reduced immune response until some additional stressor is added. 
Wright and Kyhn (2015) provide some guidelines on how to manage human activities in a particular area in a way that is reducing the chance for negative effects. One advice they give is the use of ZeroSum Management. This means that one considers the current level of impact from human activities as the maximum allowable, thus requiring a reduction of impacts before additional activities can be permitted. This approach should not prevent efforts to reduce overall impacts, but it does provide a clear framework when considering additional human activities in an area, even if the current or potentially future impact is not known.

Data needs:

For the Yarari Sanctuary it is important to consider the potential impact of cumulative effects. However, at this point, the priority should be to obtain reliable baseline data on how the area is used by cetaceans and humans.

\subsection{Knowledge gaps}

The fact that human activities can be detrimental to marine mammals is well known. However, it is still challenging to determine if any specific activity or an accumulation of activities is a problem for a (local) population. In the following we are providing an overview of the most likely activities that might cause a problem in the Yarari Sanctuary. We are also giving a priority ranking to which activities most likely will have the strongest impact and where research efforts should be directed at.

This should be interpreted carefully as some of the basic information that would be needed to quantitatively assess any impact is not available. For example, it could well be that resident dolphin populations occur in the area. Resident animals that are spending all year in the Yarari waters would be more impacted by a local contamination of prey. Similarly, although we know that worldwide bycatch and entanglement is the leading cause of death for cetaceans, there has been no indications this is the case in the study area. This of course does not mean it does not occur, but until more information is available, we are assuming that this is an activity posing a low risk. 
Table 4 Overview of human-caused pressures on cetaceans in the Yarari Sanctuary, the current knowledge on the occurrence $\&$ the anticipated scale of impact as well as mitigation options.

\begin{tabular}{|c|c|c|}
\hline 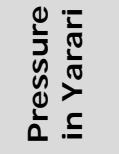 & $\begin{array}{l}\text { Knowledge / } \\
\text { data needs / } \\
\text { impact / } \\
\text { mitigation }\end{array}$ & Description \\
\hline \multirow{4}{*}{ 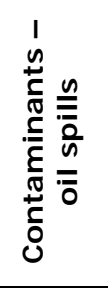 } & Knowledge & $\begin{array}{l}\text { Some data available on occurrence of oil contamination. Some indications of high } \\
\text { contaminant levels in local prey. In particular resident species that feed on local } \\
\text { prey could be impacted in their health, e.g. reproductive success. }\end{array}$ \\
\hline & Data needs & $\begin{array}{l}\text { Insufficient data on contaminant levels in cetaceans and their prey in the area } \\
\text { available. }\end{array}$ \\
\hline & Current impact & Likely high. \\
\hline & Mitigation & Prevent any contamination, e.g. through oil spills in the sanctuary or close to it. \\
\hline \multirow{4}{*}{$\frac{\dddot{n}}{20}$} & Knowledge & $\begin{array}{l}\text { Limited data on sound sources such as shipping and seismic activities. Limited } \\
\text { data on cetacean occurrence to determine a spatial overlap. }\end{array}$ \\
\hline & Data needs & Where and when does an overlap of sound production \& cetaceans occur. \\
\hline & Current impact & Unknown. \\
\hline & Mitigation & $\begin{array}{l}\text { Prohibit any activities known to cause loud noises that are harmful to marine } \\
\text { mammals. }\end{array}$ \\
\hline \multirow{3}{*}{ 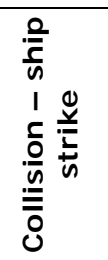 } & Knowledge & $\begin{array}{l}\text { Some ship strike events are documented in the Wider Caribbean. Reporting most } \\
\text { likely incomplete. }\end{array}$ \\
\hline & $\begin{array}{l}\text { Data needs } \\
\text { Current impact }\end{array}$ & $\begin{array}{l}\text { Spatial data on shipping activities and (large) cetacean occurrence lacking. } \\
\text { Likely low. }\end{array}$ \\
\hline & Mitigation & $\begin{array}{l}\text { If there is any potential overlap of shipping routes and whale occurrence and } \\
\text { evidence of ship strike, mitigation options include changing of shipping lanes, } \\
\text { warning systems and/or lowering shipping speed. }\end{array}$ \\
\hline \multirow{4}{*}{ 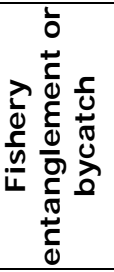 } & Knowledge & No records of entanglements or bycatches. Low fishery activity. \\
\hline & Data needs & $\begin{array}{l}\text { Spatial data lacking for fishing activities and cetacean occurrence. Lack of } \\
\text { pathological data from stranded animals or photographic documentation of } \\
\text { injuries due to fishery activities. }\end{array}$ \\
\hline & Current impact & Likely low. \\
\hline & & $\begin{array}{l}\text { If there is bycatch occurring, a number of mitigation options exist, e.g. gear } \\
\text { adaptation, acoustic deterrents. }\end{array}$ \\
\hline \multirow{4}{*}{$\begin{array}{l}\frac{n}{2} \\
\frac{0}{0} \\
0 \\
0 \\
0 \\
\frac{1}{2} \\
\Sigma\end{array}$} & Knowledge & $\begin{array}{l}\text { There is a locally high occurrence of marine debris. Current assumption is that } \\
\text { cetaceans most impacted by (macro) marine debris are deep diving cetaceans. }\end{array}$ \\
\hline & Data needs & Lack of pathological investigation on marine debris in stranded cetaceans. \\
\hline & Current impact & Likely low. \\
\hline & & $\begin{array}{l}\text { Main origin or marine debris from outside the Yarari Sanctuary. Within the } \\
\text { sanctuary, reduce marine debris from landfills (e.g. Saba) or from vessels } \\
\text { discarding trash at sea. }\end{array}$ \\
\hline \multirow{4}{*}{ 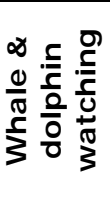 } & Knowledge & Currently no directed activity. \\
\hline & Data needs & Limited data on compliance with guidelines when interactions happen. \\
\hline & Current impact & Likely very low. \\
\hline & & $\begin{array}{l}\text { Ensure that existing or future whale and dolphin watching operation adhere to a } \\
\text { standard protocol. }\end{array}$ \\
\hline \multirow{3}{*}{ 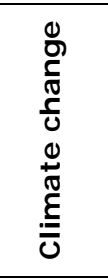 } & Knowledge & $\begin{array}{l}\text { ry little. Any changes will impact the distribution of prey and with that the } \\
\text { stribution of cetaceans. Cetaceans that are linked to a specific habitat will most } \\
\text { ely be impacted most. Most species will adapt by changing their distribution. }\end{array}$ \\
\hline & Data needs & $\begin{array}{l}\text { Information on baseline data (e.g. oceanographic measurements on } \\
\text { temperature, productivity) and changes thereof. }\end{array}$ \\
\hline & $\begin{array}{l}\text { Current impact } \\
\text { Mitigation }\end{array}$ & $\begin{array}{l}\text { Unknown. } \\
\text { No options within the Sanctuary. }\end{array}$ \\
\hline \multirow{4}{*}{ 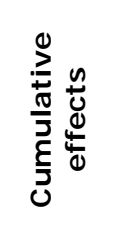 } & Knowledge & Very little knowledge available, both for the sanctuary or worldwide. \\
\hline & Data needs & $\begin{array}{l}\text { Data needed on human activities that might cause a threat and the occurrence of } \\
\text { cetaceans spatially } \& \text { temporally. Need for modelling of impacts of the different } \\
\text { threats when combined (e.g. individual based models. }\end{array}$ \\
\hline & & Unknown. \\
\hline & & Mitigating the single effects. \\
\hline
\end{tabular}




\subsection{Summary assessment of threats}

\subsubsection{Analysis of current and future potential threats}

Not surprisingly, our assessment of main threats suggests that the Yarari Sanctuary contrasts in important ways with its sister sanctuaries. In ways that should not only have consequences for specific objectives but also in terms of research needs and measures for protection. For instance, Stellwagen Bank, (an important feeding area for humpback whales situated off the north-east coast of the USA, see section 3.1.2) due to its seasonal high productivity, has a combination of high density of cetaceans and fishing activity. Consequently, collision, entanglement and disturbance impacts are high in the Stellwagen Bank National Marine Sanctuary. Therefore, management activities inside the sanctuary are principally geared to addressing these three matters.

Similarly, the Marine Mammal Sanctuary of Bermuda (see section 3.1.3) is very large and has expansive commercial fishing. It is also in an area of relatively high traffic. Collisions and disturbance levels are a recognized main problems. The Sanctuario de Mamíferos Marinos de la República Dominicana (see section 3.1.4) has significant commercial fishing activity and a high density of whale watching. Also the Agoa sanctuary (see section 3.1.1) is threatened by significant human activities such as tourism, fishing, agriculture and industry. In contrast to these sanctuary areas, at present, the Yarari Sanctuary has much less human activity. It currently has no pelagic fishery taking place within it. Demersal fishing is very limited in number of boats (max 10 vessels), deployed gear and total biomass impact. There is also probably a negligible overlap in target species between fishing and the species used by whales as prey. In addition, there is no directed whale watching so impacts on the local population is probably minimal. In general the sanctuary is in a low-vessel traffic area and a large part is even completely off-limits to large vessel traffic and anchoring (PSSA status).

There is some indication that local contamination due to oil spills takes place, but it is not clear in what way this impacts the prey species or the cetaceans in the area. Also, marine debris has been found to be prevalent in the Yarari area. Most of it is probably originating from outside the sanctuary, but landfills close to water and fishery activity have been identified to be a major source of marine debris. An analyses of the marine debris could shed some light on possible mitigation actions for the Sanctuary. The impact of noise is well documented for cetaceans, however, for the Yarari Sanctuary baseline data on what kind of noise is produced and what species of cetaceans would be affected is still lacking, making it difficult to adequately assess the impact of this potential threat at this point in time. In general, the lack of data on how marine mammals use the Yarari Sanctuary - both in space and time - makes it difficult to adequately assess the risk of any current of future activity. As highly migratory species cetaceans are subject to human activities and the potential threats they pose throughout their range. Many of the threats are present on a much larger scale outside the sanctuary and could have a large impact on the cetaceans occurring locally in the Yarari Sanctuary. Thus, human caused threats are part of a regional as well as global problem and they should both be studied and addressed as such. This underscores the importance of international cooperation for cetacean conservation at all levels.

It is likely that human pressures to exploit and use the waters of Yarari for various purposes will grow in the future. This means that the present time offers an opportunity to implement legal instruments to address and exclude potential and anticipated problems before they become controversial and before they can form become a problem in the future. For instance, one industry that has been growing very rapidly throughout the Caribbean is whale watching (Hoyt and Hyengaard 2002, Vail 2005). It is critical to design and implement proper legislation to guide this development from the onset. Developing and installing such legislation might be considered a priority activity for Yarari Sanctuary for the first 5-year period.

Another example comes from the fact that the Dutch Caribbean EEZ at present has no international pelagic offshore fishery (ie no trawling, no long-lining and no purse-seining) due to a moratorium invoked based on the premise of overfishing. No permits have recently been issued for Dutch Caribbean waters (S. mambi, pers. comm. to A. Debrot). However, such fishing activity cannot be excluded in the future. Therefore, even though not a problem at the present time inside Yarari, it 
would still be highly opportune to upgrade the current deficient fisheries legislation to exclude deleterious fishing practices for the future.

Based on our analysis of current and future potential threats, we can recommend several legal and regional goals and initiatives with which to upgrade and reinforce Yarari marine mammal conservation. In addition our analysis allows the identification of several research priorities.

\subsubsection{Recommendations on threats to address}

- Upgrade fishery gear restrictions and legislation and continue enforcement inside Yarari

- Install whale watching guidelines and legislation

- Install procedures and guidelines to regulate and limit anthropogenic sound inside Yarari

- Expand the Yarari Sanctuary to include other EEZ zones of the Dutch Caribbean

- Participate in regional efforts to address pollution and study contaminant levels in local fish stocks

- Participate in regional efforts to address direct and indirect fishing mortality

\subsubsection{Recommendations on key research and monitoring}

- Monitor fishery activity, ship traffic and as well as potential interaction inside Yarari

- Monitor cetacean distribution and abundance inside the Yarari Sanctuary at different times of the year

- Monitor background noise levels inside Yarari

- Determine contaminant loads of the cetaceans inside Yarari and their prey species

- Determine the source of marine debris found in the sanctuary 


\section{Management insights from marine mammal sister sanctuaries}

\subsection{Introduction}

Because as a rule cetaceans are strongly transboundary species, typically migrating hundreds or even thousands of kilometres each year to fulfil their lifecycle requirements, coherent and complementary management throughout their migratory range is important. To this end, it is of great value to align management priorities for the Yarari Sanctuary to those of other sanctuaries in the region. In this chapter a management overview of the four most relevant sister sanctuaries will be provided to assess some constraints and needs to effective sanctuary implementation and help with an initial scoping of management priorities for Yarari (see chapter 5). This will contribute to strategic alignment of management priorities and goals for the species of concern throughout their larger habitat, and help maximise the protection of transboundary populations of marine mammals. The need for an international, regional approach has also been acknowledged by other sanctuaries, e.g. Agoa (Agence des aires marines protégées) 2014.

There are several marine mammals conservation and management sites in the surrounding area of the Caribbean Sea and in the Atlantic Ocean (Figure 15, Table 5). The geographic boundaries of the areas are presented in Figure 16. Besides Yarari (the non-contiguous EEZs of Dutch Caribbean islands Bonaire and Saba), these are: Stellwagen (USA), Bermuda Marine Mammal Sanctuary (Bermuda), Bancos de la Plata y de la Navidad (Dominican Republic) and Agoa (around the French Antillean islands of Guadeloupe, Martinique and Saint Martin). These sanctuaries will be described in this section, specifically focussed on (priorities of) management. 


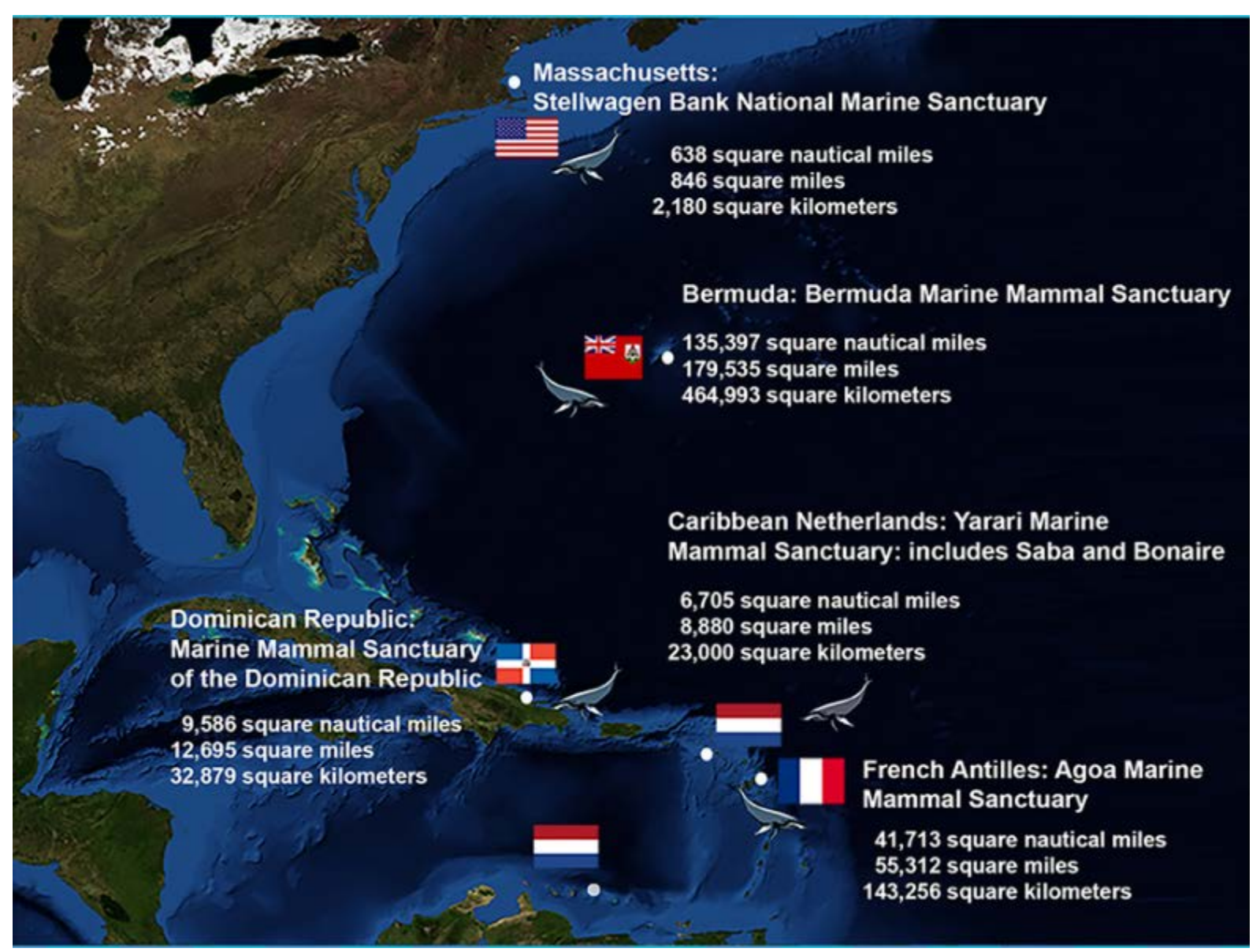

Figure 15 Map of marine mammal sanctuaries in the Caribbean and surrounding area (http://www.caribtails.org/conservation.html).

Table 5 Overview of marine mammal sanctuaries in the proximity of the Yarari Sanctuary

\begin{tabular}{|c|c|c|c|c|}
\hline & Agoa & Stellwagen & Bermuda & Dominican Republic \\
\hline Designation year & 2012 & 1992 & 2011 & $\begin{array}{l}\text { 1986, expanded in } \\
1996 \text { and } 2004\end{array}$ \\
\hline $\begin{array}{l}\text { Protected } \\
\text { species/habitats }\end{array}$ & Marine mammals & $\begin{array}{l}\text { Habitats and species } \\
\text { (lobster, fish, marine } \\
\text { mammals, birds) }\end{array}$ & Marine mammals & Marine mammals \\
\hline Legislation & $\begin{array}{l}\text { A Specially Protected } \\
\text { Areas and Wildlife } \\
\text { (SPAW) protected area } \\
\text { under the Cartagena } \\
\text { Convention }\end{array}$ & $\begin{array}{l}\text { The National Marine } \\
\text { Sanctuaries Act }\end{array}$ & $\begin{array}{l}\text { Issued under the } \\
\text { 1972 Fisheries } \\
\text { Act (1972: 76) }\end{array}$ & $\begin{array}{l}\text { The Sectoral Law on } \\
\text { Protected Areas }\end{array}$ \\
\hline Authorities & $\begin{array}{l}\text { French Marine Protected } \\
\text { Areas Agency (Agence } \\
\text { des aires marines } \\
\text { protégées) }\end{array}$ & $\begin{array}{l}\text { Office of National Marine } \\
\text { Sanctuaries, part of the } \\
\text { U.S. Department of } \\
\text { Commerce, National } \\
\text { Oceanic and Atmospheric } \\
\text { Administration (NOAA) }\end{array}$ & $\begin{array}{l}\text { The government } \\
\text { of Bermuda }\end{array}$ & Dominican Republic \\
\hline Area size & $143,256 \mathrm{~km} 2$ & $2,180 \mathrm{~km} 2$ & $464,993 \mathrm{~km} 2$ & Appr. 50,000 km2 \\
\hline $\begin{array}{l}\text { Nearest distance } \\
\text { to Northern part of } \\
\text { Yarari }\end{array}$ & $\begin{array}{l}0 \mathrm{~km} \text { (sector around St. } \\
\text { Martin) } \\
125 \mathrm{~km} \text { (sector around } \\
\text { Guadeloupe and } \\
\text { Martinique }\end{array}$ & $2750 \mathrm{~km}$ & $1200 \mathrm{~km}$ & $500 \mathrm{~km}$ \\
\hline Depth & Up to $4000 \mathrm{~m}$ & $20->200 m$ & $50-2500 m$ & $0-4263 m$ \\
\hline Zones/habitat & $\begin{array}{l}\text { Intertidal habitat, } \\
\text { continental shelf } \\
\text { (average depth } 200 \mathrm{~m} \text { ), } \\
\text { continental slope (depth } \\
\text { up to } 1100 \mathrm{~m} \text { ), abyssal } \\
\text { plain (depth generally } \\
4000 \mathrm{~m} \text { ) }\end{array}$ & $\begin{array}{l}\text { Open ocean and submerged } \\
\text { shallow benthic bank. } \\
\text { Sediments of gravel, sand } \\
\text { and mud }\end{array}$ & $\begin{array}{l}\text { Submerged } \\
\text { seamounts ( } 50- \\
2500 \text { m depth), } \\
\text { reefs and } \\
\text { seagrass beds }\end{array}$ & $\begin{array}{l}\text { A variety of habitats } \\
\text { (ocean waters, coral } \\
\text { reefs, seagrasses), } \\
\text { related mainly with } \\
\text { depth, current and } \\
\text { substrate. }\end{array}$ \\
\hline
\end{tabular}




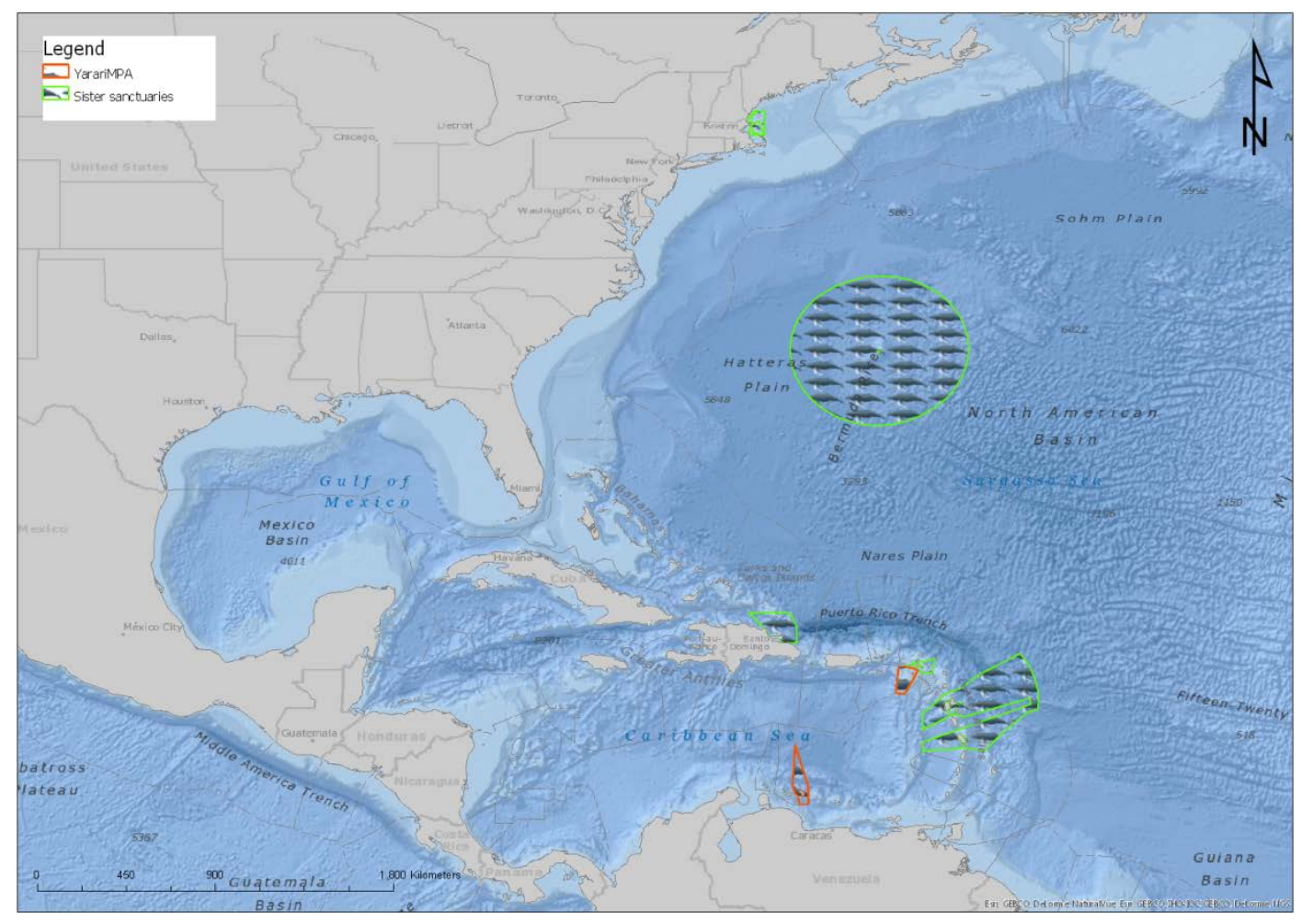

Figure 16 Location and size of the two current Yarari sectors and sister sanctuaries in the Western Antlantic.

\subsection{Sanctuaries}

\subsubsection{AGOA Sanctuary}

Agoa Sanctuary is located in the eastern Caribbean Sea (Figure 16). It has been designated in 2012 as a Specially Protected Areas and Wildlife (SPAW) protected area under the Cartagena Convention. It compasses two sectors with a total area of 143,256 km² and lies 0 (St. Martin sector) to $125 \mathrm{~km}$ (Guadeloupe and Martinique) from Yarari (Fig 17; see also Table 5). It includes intertidal habitat, continental shelf (average depth $200 \mathrm{~m}$ ), continental slope (depth up to $1100 \mathrm{~m}$ ) and abyssal plain (depth generally $4000 \mathrm{~m}$ ).

The sanctuary is designed to ensure the conservation of marine mammals in waters under French sovereignty and jurisdiction in the French West Indies. These include the territorial waters and Exclusive Economic Zones (EEZ's) surrounding Martinique, Guadeloupe and its dependencies of Marie Galante, the Saints Archipelago, la Desirade, Petite Terre, as well as those of St. Barthelemy and St. Martin (Agence des aires marines protégées 2014. 


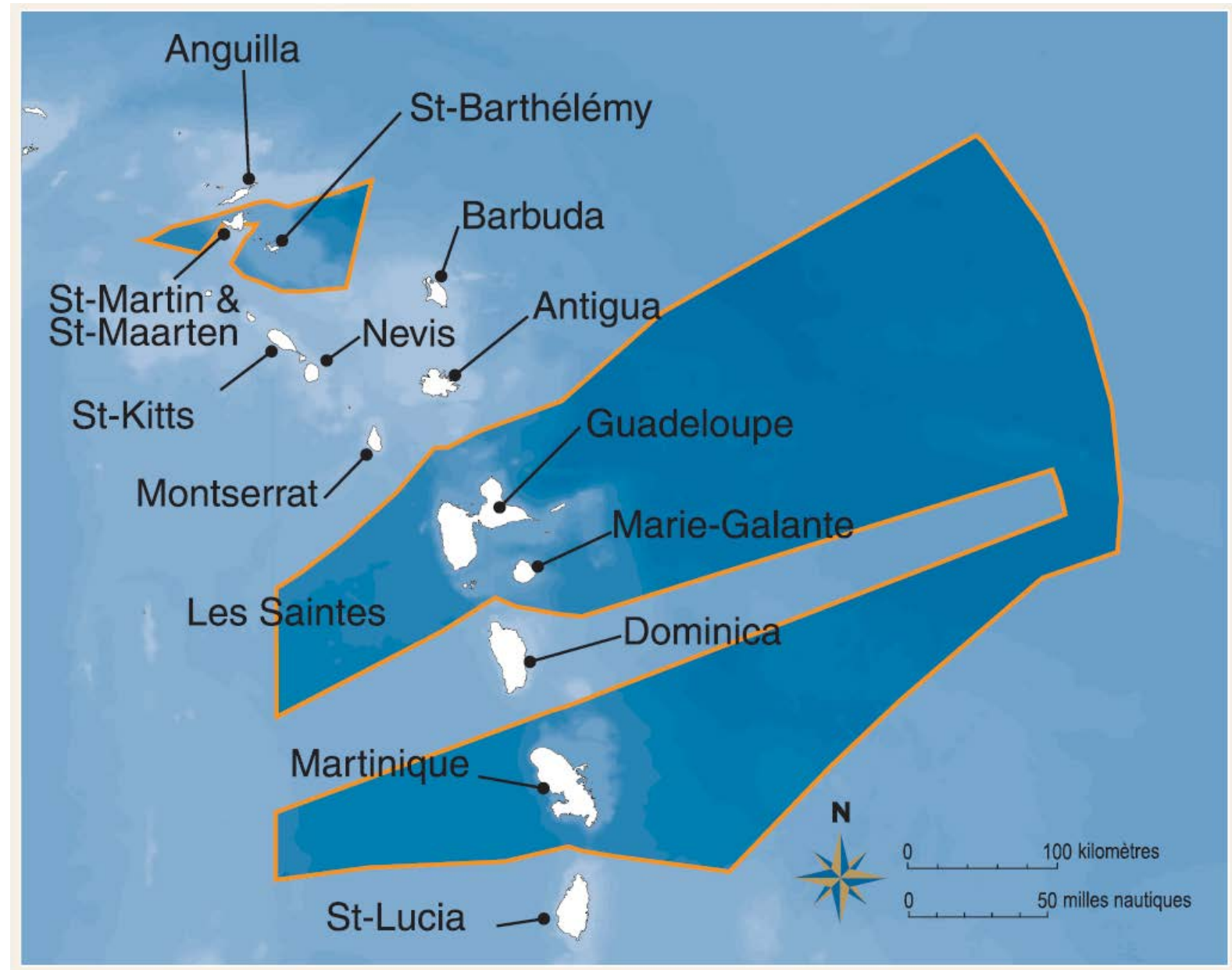

\section{Agoa's perimeter (143256 km²)}

Figure 17 Map of the Agoa sanctuary, which corresponds to the entire surface area of the French West Indies Exclusive economic zone (EEZ) (Agence des aires marines protégées 2014).

\section{Area importance}

The Caribbean Sea is a special habitat for feeding, reproduction and migration of marine mammals. Twenty-four species have been identified in the French Antilles waters (Table 6; Agence des aires marines protégées $2012 \& 2014)$.

The area consists of several zones (UNEP 2012):

- The intertidal habitats are rarely frequented by whales but they are very important because they provide breeding areas for fish and other prey.

- The continental shelf slopes gently from the shore at an average depth of 200 meters and is a rich food source for whales and other predators.

- The continental slope or bathyal zone which descends more abruptly ends at a depth of about 1100 meters or more and is frequented by some marine mammals like the sperm whale.

- The abyssal plain is itself extremely flat and occupies over $40 \%$ of sea area. Its depth varies by region but is generally 4000 meters. 
Table 6 Species identified in Agoa (Agence des aires marines protégées, 2012)

\begin{tabular}{|c|c|c|c|}
\hline \multicolumn{2}{|c|}{$\begin{array}{l}\text { Tableau n }{ }^{\circ} \text { - Etat de la composition du peuplement dans le sanctuaire Agoa } \\
\text { Juillet } 2008 \text {. }\end{array}$} & $\begin{array}{l}\text { Guadeloupe } \\
\text { et îles du Nord }\end{array}$ & \multirow[t]{2}{*}{ Martinique } \\
\hline Famille & Nom commun & Observations & \\
\hline \multicolumn{4}{|l|}{ Balaenopteridae } \\
\hline Megaptera novaeangliae & Baleine à bosse & \multicolumn{2}{|c|}{ Régulière } \\
\hline Balaenoptera edeni & Rorqual de bryde & Rare & $\mathrm{xxx}$ \\
\hline Balaenoptera acurostrata & 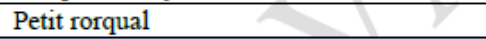 & \multicolumn{2}{|c|}{ Rare } \\
\hline \multicolumn{4}{|l|}{ Physeteridae } \\
\hline Physeter macrocephalus & Cachalot & \multicolumn{2}{|c|}{ Régulière } \\
\hline \multicolumn{4}{|l|}{ Kogiidae } \\
\hline Kogia breviceps & Cachalot pygmée & Rare & $\mathrm{xxx}$ \\
\hline Kogia simus & Cachalot nain & Occasionnelle & Régulière \\
\hline \multicolumn{4}{|l|}{ Delphinidae } \\
\hline Stenella attemuata & Dauphin tacheté pantropical & \multicolumn{2}{|c|}{ Régulière } \\
\hline Stenella clymene & Dauphin Clymène & $\mathrm{xxx}$ & Rare \\
\hline Stenella coeruleoalba & Dauphin rayé & \multicolumn{2}{|c|}{ Rare } \\
\hline Stenella frontalis & Dauphin tacheté de l'Atlantique & Rare & Occasionnelle \\
\hline Stenella longirostris & Dauphin à long bec & Rare & Occasionnelle \\
\hline Steno bredanensis & Sténo rostré & \multicolumn{2}{|c|}{ Occasionnelle } \\
\hline Feresa attemuata & Orque naine & \multicolumn{2}{|c|}{ Occasionnelle } \\
\hline Globicephala macrorhynchus & Globicéphale tropicale & Occasionnelle & Régulière \\
\hline Grampus griseus & Dauphin de Risso & $\mathrm{xxx}$ & Rare \\
\hline Lagenodelphis hosei & Dauphin de Frazer & occasionnelle & Régulière \\
\hline Orcinus orca & Orque & \multicolumn{2}{|c|}{ Rare } \\
\hline Peponocephala electra & Dauphin d'Electre & Rare & Occasionnelle \\
\hline Pseudorca crassidens & Faux orque & \multicolumn{2}{|c|}{ Occasionnelle } \\
\hline Tursiop truncatus & Grand dauphin & Occasionnelle & Régulière \\
\hline \multicolumn{4}{|l|}{ Ziphiidae } \\
\hline Ziphius cavirostris & Baleine à bec de Cuvier & \multicolumn{2}{|c|}{ Rare } \\
\hline Mesoplodon densirostris & Mesoplodon de Blainville & \multicolumn{2}{|c|}{ Rare } \\
\hline Mesoplodon europaeus & Mesoplodon de Gervais & \multicolumn{2}{|c|}{ Occasionnelle } \\
\hline \multicolumn{4}{|l|}{ Trichechidae } \\
\hline Trichecus manatus manatus & Lamentin des Caraibes & \multicolumn{2}{|c|}{ Disparu } \\
\hline \multicolumn{4}{|l|}{ Phocidae } \\
\hline Monachus tropicalis & Phoque moine des Caraibes & \multicolumn{2}{|c|}{ Eteint } \\
\hline
\end{tabular}

One remark is worth noting regarding the above listing of the West-Indian manatee, as no longer present in the French Caribbean AGOA area. Debrot et al. (2006) list recent records of manatee vagrancy for both Curaçao and St. Maarten. So while the actual occurrence of the species in Agoa is undoubtedly very low, scattered records can still be expected for animals straying east from their current area of concentration around Puerto Rico and other islands of the Greater Antilles. At present efforts are underway by Guadeloupe National Park (the LIFE SIRENIA project;

http:// www. guadeloupe-parcnational.fr/?Projet-LIFE-SIRENIA), to reintroduce the species to Guadeloupe, which formerly was an important historic area of occurrence in the lesser Antilles (Richard 2001).

\section{Governance}

Agoa is governed by a management board which has 53 members, representing the diversity of the islands of Guadeloupe, Martinique, Saint-Martin and Saint-Barthélemy. It consists of coastal and marine stakeholders from various sectors and interest groups: local officials, professional fishermen, leisure users, the tourist sector, environmental protection societies, experts and Government services (Agence des aires marines protégées 2014). The management board defines the sanctuary's policy: management plan, programme of action, and monitoring and assessment. It prepares proposals for the competent government authorities concerning the supervision or regulation of activities which could negatively impact marine mammals.

\section{Pressures}

Several environmental pressures and risks have been identified as relevant to the marine mammals of Agoa (Agence des aires marines protégées 2014):

- Collision risks

Shipping and boating can cause collisions. 
- Environmental pollution

Bio-accumulation of contaminants takes place in the food chain and causes a high level of contamination in cetaceans due to their position as top predators.

- Disturbance

The activity of "whale watching" can be a source of disturbance to cetaceans and must be done respectfully to ensure their tranquillity.

- Noise

Military manoeuvres and submarine construction generate noise disturbance, as does marine traffic. This sound pollution is detrimental to cetaceans' orientation and communication and can sometimes lead to stranding.

- Incidental catches

Fishing can be a source of incidental catches of small and large cetaceans, which, although not always fatal, considerably reduce the animals' capacities and vitality.

- Marine litter

Waste can hamper the animals or even be ingested (causing asphyxia, blockage, etc.).

To manage or reduce sources of pressure, Agoa develops awareness programs and coordinates stakeholder initiatives; its management board may also recommend the implementation of regulatory measures (Agence des aires marines protégées 2014). There are two permanent staff members for the management of the Agoa sanctuary and there is additional support from the staff (about 4 people working on the sanctuary issues) of the French Marine Protected Areas Agency (UNEP 2012). The annual budget from the French Marine Protected Areas Agency (operating costs) and SPAW-RAC (scientific mission) is 400,000 USD (UNEP 2012).

\section{Aim and actions}

The Agoa sanctuary aims to ensure good marine mammal conservation by protecting both the mammals and their habitats from the direct or indirect, potential or proven, adverse impacts of human activities. Management action is guided by five principles set out in the declaration establishing the sanctuary (Agence des aires marines protégées 2014):

1. Protect

Restrict negative interactions between human activities (direct or indirect, potential or known) and marine mammals and find innovative ways of limiting the impact these activities have (Declaration $\S 5 \& 6$ ).

2. Understand

Enhance knowledge of marine mammal populations and their habitats and of potential or known human induced pressures and threats facing these species (Declaration $\S 7$ ).

3. Share

Disseminate knowledge (information, awareness arising, education) and promote the Agoa sanctuary, marine mammals and the marine environment in general (Declaration § 8).

4. Inform Implement the resources required to monitor the sanctuary within the framework of pooling State resources. (Declaration § 9).

5. Cooperate

Cooperate with the other States in the Caribbean and particularly with the Parties to the Cartagena Convention and its Protocol on Specially Protected Areas and Wildlife (SPAW) as well as States sharing transboundary marine mammal populations, to foster the introduction of conservation and management measures that are coherent with those of the Agoa sanctuary (Declaration § 12).

\subsubsection{Stellwagen Bank National Marine Sanctuary}

The Stellwagen Bank National Marine Sanctuary stretches between Cape Ann and Cape Cod at the mouth of Massachusetts Bay in the southwestern corner of the Gulf of Maine (Figure 18). The sanctuary protects 842 square miles ( 638 square nautical miles or $2181 \mathrm{~km} 2$ ) of open ocean. It lies $2750 \mathrm{~km}$ from Yarari. The sanctuary contains three basic physical habitat types: gravel, sand and mud with the following coverage: $34 \%, 28 \%$ and $38 \%$, respectively. It has depths that range from 20 to greater than $200 \mathrm{~m}$ (NOAA 2010). 


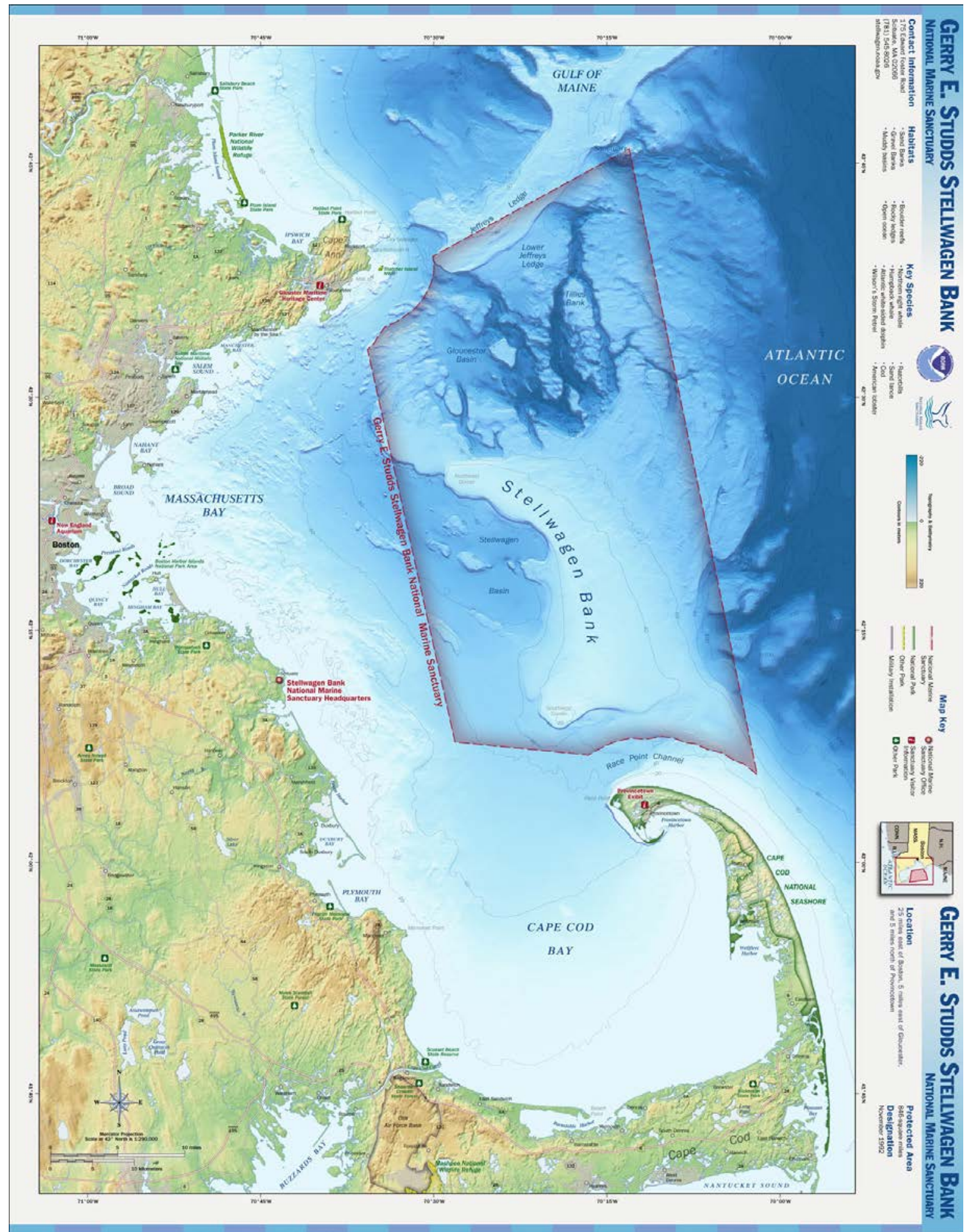

Figure 14 Map of Stellwagen sanctuary

(http://sanctuaries.noaa.gov/pgallery/atlasmaps/images/sb_2000.jpg).

\section{Area importance}

The sanctuary protects both open ocean and submerged shallow (20-40 m) benthic bank habitat , including the living and non-living resources within those waters. Water depths over and around the bank range from $20 \mathrm{~m}$ to more than $180 \mathrm{~m}$ (National Marine Sanctuary Program 2006). For many of the marine mammal species, waters of the sanctuary serve as primary habitat for critical activities that include feeding and nursing.

Stellwagen Bank is a rich and productive fishing ground, particularly for groundfish species like cod, haddock and flounder, but also Atlantic bluefin tuna, large sharks, and large schools of herring. The area is well known as a whale watching destination. Humpback whales have a long seasonal residence 
in the sanctuary. In addition to humpbacks, fin whales, minke whales, white-sided dolphins and harbour porpoises are commonly seen. North Atlantic right whales are less frequently encountered, owing both to their critically endangered population status (i.e., fewer right whales overall to frequent the sanctuary), to the shorter period of residence within the sanctuary (generally late winter or early spring to approximately July) and regulations restricting vessel approach (NOAA 2010). In total 22 species of marine mammals have been sighted in the Stellwagen Bank sanctuary (Table 7). New research indicates that minke whales might migrate from this area to the Caribbean (see Chapter 2). For humpback whales migration routes have been documented for the Caribbean and Stellwagen Bank (Katona and Beard 1990), but not specifically for Yarari.

Local availability of sand lance, the main food source of humpback and fin whales, attracts the whales to the sanctuary (NOAA 2010). Sand lance numbers in the sanctuary are the highest and most concentrated anywhere in the southern Gulf of Maine, and the sanctuary is in an area of high relative abundance of herring. Accordingly, the sanctuary is one of the most intensively used whale habitats in the northeast continental region of the U.S. (NOAA 2010).

Table 7 List of 22 species of marine mammals sighted in the Stellwagen Bank sanctuary (NOAA, 2010).

\begin{tabular}{|c|c|c|}
\hline Group & Common Name & Scientific Name \\
\hline \multirow{6}{*}{$\begin{array}{l}\text { Baleen Whales } \\
\text { (Mysticetes } n=6 \text { ) }\end{array}$} & Blue whale & Balaenoptera musculus \\
\hline & Fin or Finback whale & Balaeneptera physalus \\
\hline & Humpback whale & Megaptera novaeangliue \\
\hline & Sei whale & Balaenoptera borealis \\
\hline & Minke whale & Balaenoptera acutorostrata \\
\hline & North Atlantic right whale & Eubalaena glacialis \\
\hline \multirow{11}{*}{$\begin{array}{l}\text { Toothed Whales } \\
\text { (Odontocetes } n=11 \text { ) }\end{array}$} & Sperm whale & Physeter macrocephalus \\
\hline & Long-finned Pilot whale & Globicephala melaena \\
\hline & Atlantic White-Sided Dolphin & Lagenorhynchus acutus \\
\hline & White-Beaked Dolphin & Lagenorhynchus albirostris \\
\hline & Harbor Porpoise & Phocoena sp. \\
\hline & Bottlenose Dolphin & Tursiops truncatus \\
\hline & Common Dolphin & Delphinus delphis \\
\hline & Striped Dolphin & Stenella coeruleoalba \\
\hline & Grampus (Risso's) Dolphin & Grampus griseus \\
\hline & Killer whale or Orca & Orcinus orca \\
\hline & Beluga & Delphinus leucas \\
\hline \multirow{5}{*}{$\begin{array}{l}\text { Seals } \\
\text { (Pinnipeds } n=5 \text { ) }\end{array}$} & Harbor Seal & Phoca vitulina \\
\hline & Gray Seal & Halichoerus grypes \\
\hline & Harp Seal & Pagophilus groenlandica \\
\hline & Hooded Seal & Cystophora cristata \\
\hline & Ringed Seal & Pusa hispida \\
\hline
\end{tabular}

\section{Governance}

The Stellwagen Bank National Marine Sanctuary is one of 13 sites managed under the National Marine Sanctuary Program, located within the National Ocean Service of the National Oceanic and Atmospheric Administration (NOAA). The sanctuary is managed by a sanctuary superintendent, and supported by sanctuary staff. The sanctuary superintendent oversees site-specific management functions, including revision and implementation of the management plan (NOAA 2010). The superintendent designates responsibility for implementing specific programs or projects, establishes 
the administrative framework to ensure all resource management activities are coordinated, and maintains and manages an appropriate infrastructure to adequately support site operations. The superintendent reports to the Regional Superintendent for the Northeast and Great Lakes Region of the Office of National Marine Sanctuaries (ONMS). Basic staffing supports program activities in different areas and has knowledge and expertise in policy, marine resource management, education and outreach, scientific research and monitoring, maritime heritage resources, geographic information systems (GIS), information technology, program development and office administration. In 2010 there were seven full-time staff, four of whom were federal employees and three were contract employees. Five other contract employees were part-time status. There also was one post-doctoral fellow working with the sanctuary (NOAA 2010). This means in total eight full-time and five part-time employees. The sanctuary is part of an international collaboration for protection of the humpback whale (see section "the Sister Sanctuary Program").

\section{Pressures}

The sanctuary is a high-use area for commercial and recreational vessel traffic that can cause disturbance to or collide with whales, and major commercial fisheries in the sanctuary are identified entanglement risks. Several pressures and their sources are identified for the Stellwagen sanctuary (NOAA, 2010). Here, the pressures of concern for marine mammals are listed:

- $\quad$ Fishing

o Commercial fishing of herring, representing potential human food competition is a concern in the area. The availability of herring, particularly as a functional prey substitute for sand lance, may be a factor in determining the local abundance of whales, dolphins and other wildlife in the sanctuary.

o Fishing gear entanglement observations are relatively high in the Stellwagen area.

- Vessel traffic

o Approximately $10 \%$ of the vessel/whale collisions recorded world-wide were reported from the sanctuary area including Cape Cod Bay and Boston Harbor. Species struck included fin, humpback, sei, minke and North Atlantic right whale.

o Commercial and recreational vessel traffic can cause disturbance to whales (whale watch season is from May to September).

\section{Aim and actions}

The sanctuary's mission is to conserve, protect and enhance the biological diversity, ecological integrity and cultural legacy of the sanctuary while facilitating uses that are compatible with the primary goal of resource protection (NOAA 2010).

Three action plans have been established regarding marine mammal protection in the sanctuary (NOAA 2010):

A. The Marine Mammal Behavioral Disturbance (MMBD) Action Plan establishes a framework to address the potential for marine mammal harassment and behavioural disturbance resulting from whale watching, tuna fishing, aircraft overflights and noise pollution (Table 8).

B. The Marine Mammal Vessel Strike (MMVS) Action Plan identifies means to assess and reduce marine mammal vessel collision that cause serious injury and mortality (Table 9)

C. The Marine Mammal Entanglement (MME) Action Plan characterizes the threat of marine mammal entanglement with fishing gear (Table 10).

Each plan formulates methods to work with user groups and cross-jurisdictional partners to minimize risk. The Stellwagen management plan (NOAA 2010) includes an indication of estimated costs for implementation of action plans and lists performance measures.

Fishing is not regulated within the Stellwagen management plan. Fishery resources in the sanctuary are regulated by NOAA Fisheries Service with input from the NEFMC, the Mid-Atlantic Fishery Management Council (MAFMC) and the Atlantic States Marine Fisheries Commission (ASFMC). Some restrictions on fishing that affect the sanctuary have been put in place, including limited access programs and effort controls, rolling closures for groundfishing, catch and minimum size limits for individual species, and a large, permanent year-round habitat closure in the Western Gulf of Maine Closed Area (WGoMCA). A Fishery Management Plan (FMP) has been implemented, including management measures such as: reduction in the number of days at sea; minimum size regulations for 
several major commercial and recreational species; closed areas; increase in the mesh size of mobile trawl gear and gillnets; limits to hook size and number for hook gear; marking requirements for gillnet gear (NOAA, 2010).

Table 84 Objectives and strategy of the Marine Mammal Behavioral Disturbance (MMBD) Action Plan (NOAA 2010).

\begin{tabular}{|c|c|c|}
\hline Objective & Strategy & Priority \\
\hline \multirow{4}{*}{$\begin{array}{l}\text { MMBD. } 1 \text { Reduce Marine Mammal } \\
\text { Behavioral Disturbance and Harass- } \\
\text { ment by Vessels }\end{array}$} & $\begin{array}{l}\text { (1.1) Develop and implement management measures that mitigate behavioral } \\
\text { disturbance and risk to whales due to vessel speed and close approach. }\end{array}$ & High \\
\hline & $\begin{array}{l}\text { (1.2) Develop a process to consider prohibiting vessels from transiting through } \\
\text { humpback whale bubble clouds and/or nets. }\end{array}$ & High \\
\hline & $\begin{array}{l}\text { (1.3) Conduct risk assessment on other activities that could disturb marine } \\
\text { mammals. }\end{array}$ & Low \\
\hline & $\begin{array}{l}\text { (1.4) Develop a research program to better understand vessel interactions with } \\
\text { whales. }\end{array}$ & High \\
\hline \multirow{3}{*}{$\begin{array}{l}\text { MMBD.2 Reduce Marine Mammal } \\
\text { Behavioral Disturbance and Harass- } \\
\text { ment by Noise }\end{array}$} & $\begin{array}{l}\text { (2.1) Establish a Marine Noise Consortium to identify noise sources and possi- } \\
\text { ble effects. }\end{array}$ & High \\
\hline & $\begin{array}{l}\text { (2.2) Develop a marine acoustics research program to establish baseline noise } \\
\text { levels and long-term noise budgets. }\end{array}$ & High \\
\hline & $\begin{array}{l}\text { (2.3) Develop a policy framework for investigating and mitigating noise } \\
\text { impacts within SBNMS. }\end{array}$ & High \\
\hline \multirow{2}{*}{$\begin{array}{l}\text { MMBD. } 3 \text { Reduce Marine Mammal } \\
\text { Behavioral Disturbance and Harass- } \\
\text { ment by Aircraft }\end{array}$} & $\begin{array}{l}\text { (3.1) Identify information gaps and gather data on overflight activities to deter- } \\
\text { mine whether they disturb marine mammals. }\end{array}$ & Low \\
\hline & $\begin{array}{l}\text { (3.2) Develop outreach advisories with NOAA Fisheries Service to inform the } \\
\text { aviation community regarding overflight in proximity to whales. }\end{array}$ & Low \\
\hline
\end{tabular}

Table 9 Objectives and strategy of the Marine Mammal Vessel Strike (MMVS) Action Plan (NOAA, 2010).

\begin{tabular}{|l|l|c|}
\hline \multicolumn{1}{|c|}{ Objective } & \multicolumn{1}{|c|}{ Strategy } & Priority \\
\hline \multirow{4}{*}{$\begin{array}{l}\text { MMVS.1 Reduce the Risk of Vessel } \\
\text { Strike between Large Commercial } \\
\text { Ships and Whales }\end{array}$} & $\begin{array}{l}\text { (1.1) Consult with NOAA Fisheries Service on their proposed strategy to reduce } \\
\text { ship strike to North Atlantic right whales and evaluate how such measures } \\
\text { would affect the sanctuary. }\end{array}$ & High \\
\cline { 2 - 4 } & $\begin{array}{l}\text { (1.2) Develop, demonstrate and evaluate the SBNMS Information and Report- } \\
\text { ing Center. }\end{array}$ & High \\
\cline { 2 - 4 } & $\begin{array}{l}\text { (1.3) Determine the conservation benefit of reconfiguring the existing Traffic } \\
\text { Separation Scheme (TSS) within the sanctuary to reduce the risk of ship strike } \\
\text { to whales. }\end{array}$ & High \\
\hline $\begin{array}{l}\text { MMVS.2 Reduce the Risk of Vessel } \\
\text { Strike through Speed Restriction on } \\
\text { Vessels }\end{array}$ & $\begin{array}{l}\text { (2.1) Institute year-round voluntary speed restrictions for all vessels operating } \\
\text { in the sanctuary. }\end{array}$ & High \\
\hline \multirow{5}{*}{$\begin{array}{l}\text { MMVS.3 Support and Develop } \\
\text { Research Programs to Reduce the } \\
\text { Risk of Vessel Strike }\end{array}$} & $\begin{array}{l}\text { (3.1) Work with NOAA Fisheries Service to support their ongoing database of } \\
\text { all known vessel strikes in and around the sanctuary. }\end{array}$ & High \\
\cline { 2 - 4 } & $\begin{array}{l}\text { (3.2) Work with NOAA Fisheries Service to institute a toll free number to } \\
\text { enable callers to anonymously report vessel strikes in the sanctuary. }\end{array}$ & Medium \\
\cline { 2 - 4 } & $\begin{array}{l}\text { (3.3) Investigate research strategies to determine responses of whales to } \\
\text { approaching vessels. }\end{array}$ & High \\
\cline { 2 - 4 } & $\begin{array}{l}\text { (3.4) Conduct year-round monitoring to identify type, size, route and speed of } \\
\text { vessels in the sanctuary. }\end{array}$ & High \\
\cline { 2 - 4 } & $\begin{array}{l}\text { (3.5) Investigate use of forward-looking sonar or other real-time detection } \\
\text { technologies. }\end{array}$ & Low \\
\hline
\end{tabular}


Table 105 Objectives and strategy of the Marine Mammal Entanglement (MME) Action Plan (NOAA, 2010).

\begin{tabular}{|c|c|c|}
\hline Objective & Strategy & Priority \\
\hline \multirow{3}{*}{ MME.1 Aid Disentanglement Efforts } & $\begin{array}{l}\text { (1.1) Maximize the degree to which entangled animals in the sanctuary are } \\
\text { sighted and reported. }\end{array}$ & High \\
\hline & (1.2) Maximize ability of vessels and aircraft to stand-by entangled animals. & High \\
\hline & $\begin{array}{l}\text { (1.3) Undertake activities leading to improved understanding and prevention } \\
\text { of entanglement events in SBNMS and improvements in disentanglement } \\
\text { technology. }\end{array}$ & Medium \\
\hline \multirow{2}{*}{$\begin{array}{l}\text { MME.2 Reduce Marine Mammal } \\
\text { Interaction with the Trap/Pot Fishery }\end{array}$} & (2.1) Obtain gear modifications. & High \\
\hline & (2.2) Serve as test-bed to develop and demonstrate low-risk fishing gear. & Medium \\
\hline \multirow{2}{*}{$\begin{array}{l}\text { MME.3 Reduce Marine Mammal } \\
\text { Interaction with the Gillnet Fishery }\end{array}$} & (3.1) Obtain gear modifications. & High \\
\hline & (3.2) Develop research programs. & Medium \\
\hline
\end{tabular}

\subsubsection{Bermuda}

Bermuda's territorial waters are protected under a marine mammal 'national sanctuary'. It compasses an area of 464,993 km² and lies $1200 \mathrm{~km}$ from Yarari. It has a varying depth from banks of $\sim 50 \mathrm{~m}$ up to abyssal depths of $\sim 2500 \mathrm{~m}$. It is the most northern outpost for Caribbean biota in the Atlantic Ocean. Bermuda is comprised of a group of islands in the Sargasso Sea that are the emergent part of the Bermuda Seamount, also called the Bermuda Platform (Figure 19). The remaining seamounts within the EEZ are completely submerged and are Challenger Bank and Plantagenet Bank (depth 50 $\mathrm{m}$ ), Bowditch Seamount (depth $\sim 600-800 \mathrm{~m}$ ), Muir Seamount (depth $200 \mathrm{~m}$ ) and deeply submerged Crescent Seamount (the deeper abyssal depths that surround the seamount is $\sim 2500 \mathrm{~m}$ ) (Government of Bermuda, 2014). The total marine area of the platform, to the $200 \mathrm{~m}$ depth contour, is estimated at $753.2 \mathrm{~km}^{2}$, and of this $326.99 \mathrm{~km}^{2}$ is considered reef. Seagrass beds are located across the platform both inshore and offshore (Government of Bermuda 2014). 


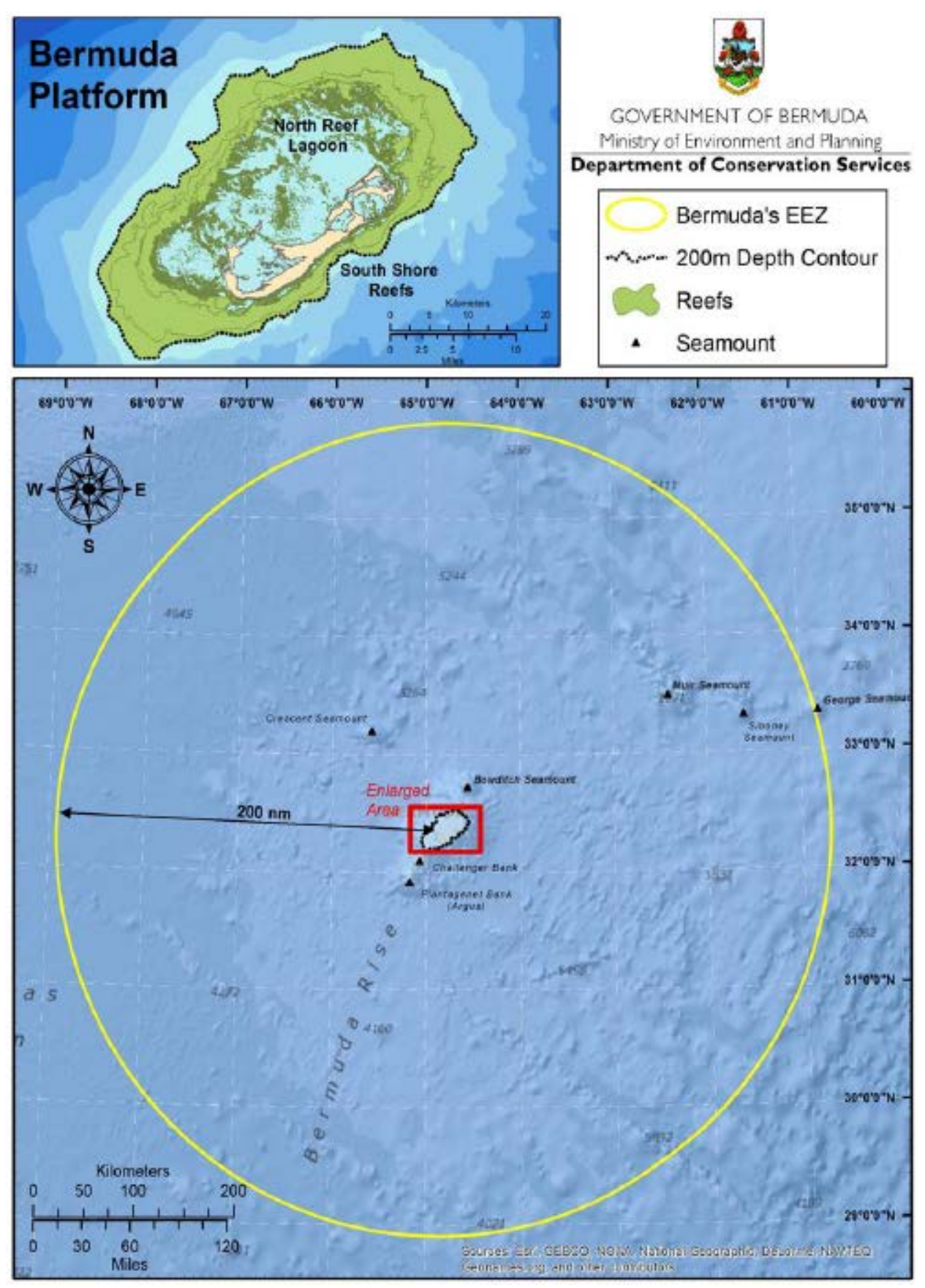

Figure 15 Bermuda Exclusive Economic Zone (Government of Bermuda 2014).

\section{Area importance}

Bermuda's EEZ is, from 20 September 2012, a sanctuary for all marine mammals. The designation process was primarily led by the Sargasso Sea Alliance (UNEP 2014). Thirty cetacean species have been recorded from the Sargasso Sea (Laffoley et al. 2011). Of particular note are humpback whales which are believed to use Bermuda as a way point on their migrations and perhaps they also use the mid-ocean seamounts in the Sargasso Sea as feeding and aggregation sites before heading north (Laffoley et al. 2011). The other large whale seen regularly in the Sargasso Sea is the sperm whale, which occur throughout the Sargasso Sea (Laffoley et al. 2011). As Bermuda is strategically situated between the humpbacks' southern calving and breeding grounds and their northern feeding/nursery grounds, marine mammal protection within the Bermuda sanctuary has particular emphasis on the humpback whale.

Additional protected species are fin whale, blue whale, sperm whale, striped dolphin, rough-toothed dolphin and pygmy sperm whale (only the last two not CMS-listed). Besides marine mammals, typical species most relevant to this policy are all seagrass species, fish and molluscs. 


\section{Governance}

In 2009, Bermuda hosted a meeting to explore opportunities for delivering better ocean protection for its surrounding seas, and the Sargasso Sea initiative was born, which in turn lead to the creation of the Sargasso Sea Alliance in 2010 (Laffoley et al. 2011). The Sargasso Sea Alliance has four overarching aims (Laffoley et al. 2011):

- To build an international partnership to secure global recognition of the importance and ecological significance of the Sargasso Sea, the threats that it faces, and the precautionary management it needs;

- To use existing regional, sectoral and international organisations to secure a range of protective measures for the Sargasso Sea;

- To establish appropriate management for the Sargasso Sea; and

- To use the current process as an example of what can and cannot be delivered through existing frameworks in marine areas beyond national jurisdictions to inform the global debate and provide a model for protection of other High Seas regions.

Within Bermuda's EEZ, humpback whales are protected by two pieces of Bermuda legislation. The Fisheries Act 1972 protects all species of whales and the Protected Species Act 2003 provides for the protection and recovery of threatened species, giving specific protection to whale species that are considered threatened. Following the declaration of the sanctuary, Bermuda established a partnership with the Stellwagen Bank National Marine Sanctuary for the protection of the humpback whale: the Sister Sanctuary Program (see section on this program under 'International cooperation').

The Department of Environment and Natural Resources (DENR) is the primary government agency responsible for ensuring the proper use of Bermuda's natural resources and the protection of the environment, within the framework of sustainable development. Established in 2016, DENR is the result of an amalgamation between the Department of Conservation Services and the Department of Environmental Protection. Marine management is one of six department programs of DENR (http://environment.bm/about-us/). Estimated expenditure for the DENR in 2016/2017 is $\$ 8,038,000$ with $\$ 6,000$ for conservation services (Government of Bermuda 2016).

The government of Bermuda provides staff and operational budget for the marine conservation section, monitoring the health of Bermuda's marine habitats and protected species, conducting research on the health of the same, species recovery plans, managing marine parks, providing technical advice to the Marine Resources Board on all marine related to ecological assessments of proposed development in marine conservation areas, promoting public awareness and to encourage community stewardship of Bermuda's marine ecology and to manage the Protected Dive Site Programme (Government of Bermuda, 2015). Available staff for marine conservation are: Principal Marine Ecologist, Marine Ecologist Assistant and Marine Technician (Government of Bermuda, 2015).

Dr. Sarah Manuel, Senior Marine Conservation Officer, states the following:

"The Bermuda Government does not allocate an annual budget, or staff, specifically to the management of Bermuda's Marine Mammal Sanctuary. All whales and dolphins in Bermuda's EEZ have been protected under the Bermuda Fisheries (Protected Species) Order since 1978. We have 5 fisheries wardens, 2 marine resource officers and 2 marine conservation officers. The cost of our 9 staff is approximately US $\$ 583,580$ per year but only an extremely small proportion of their time, if any, in a year may be spent ensuring the protection of whales through education and enforcement. We do not conduct any research on whales or dolphins in Bermuda's Marine Mammal Sanctuary, and rely on NGO's..... to monitor the whales while one of these (NGOs) has recently been conducting studies on the health of what they think is a resident bottlenose dolphin population. Our current level of staffing is sufficient for enforcement. One of our main problems is getting the judiciary to assign priority to infractions against the law."

As quoted from

Dr. Sarah Manuel 


\section{Pressures}

Current threats include (Laffoley et al. 2011):

- Impacts of fishing;

- $\quad$ Shipping and shipping related impacts;

- Pollution, including plastics.

In addition to direct fishing impacts on targeted species, the type of fishing gear used has potential impact upon by-catch. Approximately two thirds of the landings from the Sargasso Sea over the last decade have been from longlines. Gill nets are still used in the Sargasso Sea (Laffoley et al. 2011). Bermuda, however, has one of the most restrictive fisheries management regimes in the world. In Bermuda waters, fishing nets are not permitted offshore or for bottom fishing, and longline fishing is highly regulated (Government of Bermuda 2013a,b). Fisheries regulations include a ban on all dynamite fishing, use of gill nets, trawls, fish traps, and spear guns and severe restrictions on nets and long-lines. There are selected spawning grounds for protected species that experience seasonal closures by species and area, limited entry into the fishery industry, bag limits, etc. All local and visiting vessels fishing commercially in Bermuda waters must be licensed (Government of Bermuda 2014).

\section{Aim and actions}

By establishing the Marine Mammal Sanctuary, and by partnering with the Stellwagen Bank Marine Mammal Sanctuary, Bermuda has taken an important step in protecting marine mammals and in assisting in the global recovery of the humpback whale. In addition, research is promoted and encouraged, and the humpback whale is monitored. A number of areas are permanently or seasonally closed to fishing (Government of Bermuda 2014).

\subsubsection{Dominican Republic}

The Marine Mammal Sanctuary of the Dominican Republic (Sanctuario de Mamíferos Marinos de la República Dominicana), including the Silver Bank (18 m depth) and Christmas Bank, is located in the Northern part of the territorial waters of the Dominican Republic (Figure 4). It compasses an area of approximately $50,000 \mathrm{~km}^{2}$ and lies $500 \mathrm{~km}$ from Yarari. The Sanctuary compasses a variation of depths ranging from 0 meters in shallow areas off the coast of the Hispaniola island and reefs up to $4263 \mathrm{~m}$ depth in abyssal areas (República Dominicana 2015). The main habitats are the marine waters of Silver Bank, Christmas Bank and Bay Samaná, as important sites for reproduction and breeding of the largest population of North Atlantic humpback whales. Furthermore, the coral reefs of Banco de la Plata are a special aggregation site for spawning fish and form a place of shelter and/or food for a variety of fish, sea turtles and lobster. Seagrasses are important as feeding sites for the West Indian manatee (Trichechus manatus) (República Dominicana 2015). 


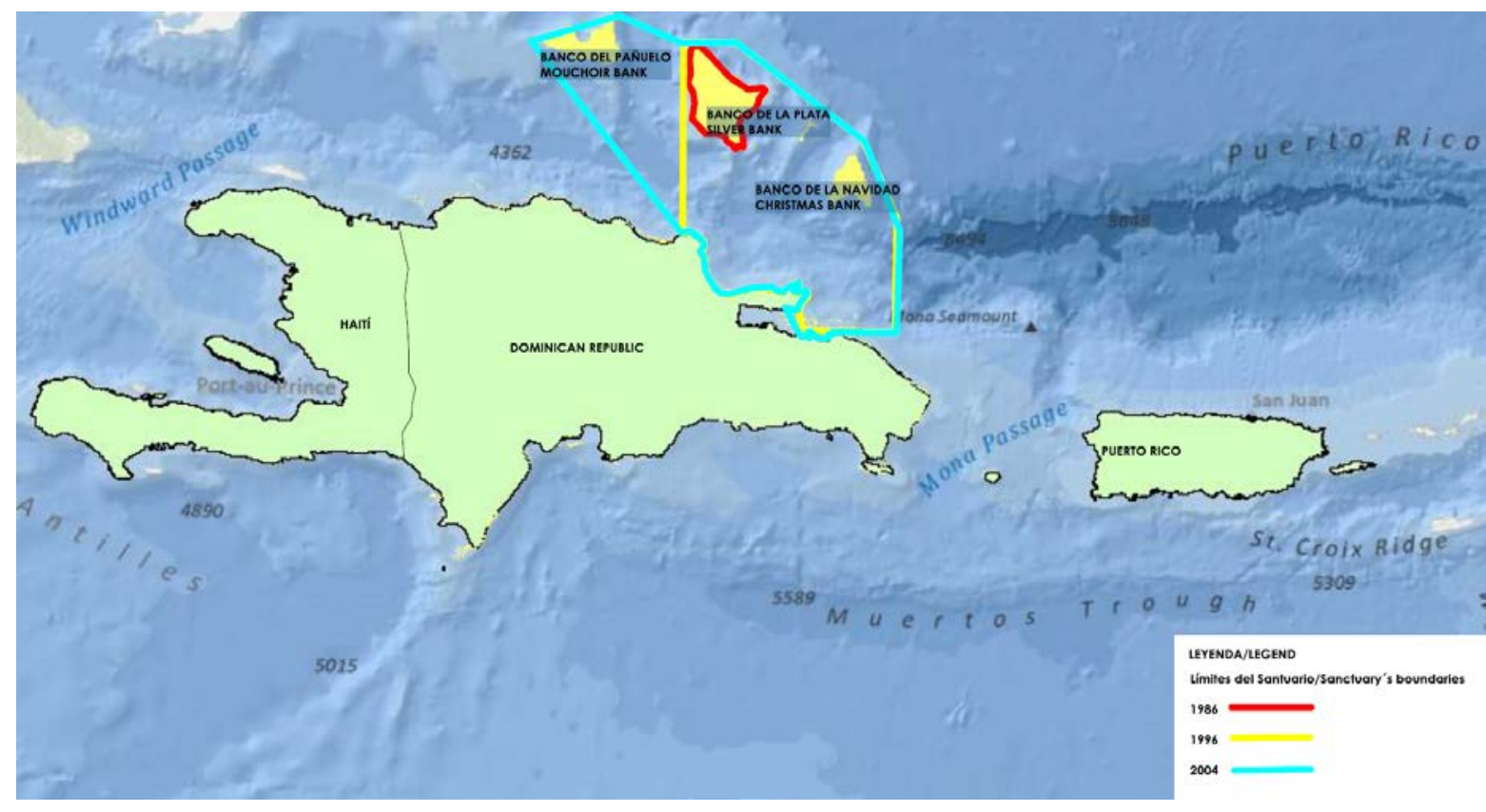

Figure 16 Map of the Marine Mammal Sanctuary of Silver and Christmas Banks, showing the 1986, 1996 and 2004 boundaries (Lancho Diéguez 2012).

\section{Area importance}

The area encompasses not only the shallower calving and breeding grounds of the Silver Bank, Navidad Bank and Samana Bay, but also all of the deeper ocean waters between, which are heavily travelled migration routes for whales headed to other parts of the Caribbean. In the 1970s it had been demonstrates that the humpback whales (Megaptera novaeangliae) of all the North Atlantic subpopulations migrate towards the Caribbean region and in particular (85\%) to Silver and Christmas Banks (Figure 20). Therefore, in 1986, the first humpback whale sanctuary in the world was declared and a decade later, it was expanded to include Christmas Bank and Samaná Bay. In 2004, the Sectoral Law on Protected Areas further expanded the boundaries of the Sanctuary to include Mouchoir Bank. Within the Sanctuary, in addition to humpback whales, sightings have been reported of other species of marine mammals including various toothed whales, such as sperm whales, pilot whales, orcas, pygmy killer whales, beaked-whales, dolphins (including both Atlantic and pantropical spotted dolphins and bottlenose dolphins) and the manatee which is a sirenian.

\section{Governance}

The government of the Dominican Republic is the responsible authority for the sanctuary. A management plan has been developed through a participatory process designed by the Ministry of the Environment and Natural Resources, involving a large number of stakeholders, both in government (Ministry of Tourism and National Council on Fishing and Aquaculture) and in the private sector (Atemar, Samaná Bay Association of Boat Owners, fishermen, Samaná tour operators, etc.) as well as civil society, represented by several NGOs, and members of nearby communities (Lancho Diéguez 2012).

Under the Life-Web project a management plan for the Dominican Republic (D.R.) is being developed and a visit to the D.R. by a six-country Eastern Caribbean delegation was realized to show the whalewatching going on in the D.R. Two areas in the Caribbean have been identified for further "scenario work": One from the D.R. down to Grenada, to build upon on-going cooperation to identify joint measures/activities for trans-boundary conservation of marine mammals (with a focus on humpback whales, sperm whales and dolphins).

\section{Pressures}

The main pressures within the Sanctuary are (República Dominicana 2015):

- accidental entanglement of cetaceans through the use fishing nets,

- pollution,

- maritime traffic, 
- climate change.

In addition, poor governance has also been identified as a threat to the Sanctuary (República Dominicana 2015).

\section{Aim and actions}

The goal of the Marine Mammal Sanctuary as described in the management plan is the development of actions in 5 years for the protection, research, management, administration and education so that $70 \%$ efficiency is reached to achieve the conservation of marine mammals in the Sanctuary, in relation to the previous situation the management plan (República Dominicana 2015).

The Management Plan also includes five strategic objectives and priorities to achieve the goal (República Dominicana 2015). These are:

1. To strengthen and / or promote an institutional, legal and regulatory framework for the effective management of the Sanctuary according to existing guidelines at national and international level.

2. Develop a sense of collective ownership of the Sanctuary at a local and regional level, promoting responsible behaviour of the users of its resources, handlers and the general public.

3. Reduce or stop the degradation and / or boost the recovery of natural and cultural resources, especially marine mammals, promoting sustainable use and compliance with national and international regulations.

4. Use existing information and generate new data as a basis for adaptive management through research and monitoring projects.

5. To ensure the availability of financial resources required for management the Sanctuary.

Until 2010 the Sanctuary staff was temporary hired during the stage of whale watching. Since 2010, the Sanctuary has a permanent manager (República Dominicana 2015).

\subsection{Summary and conclusions}

We here conduct a brief management review of four functioning western Atlantic marine mammal sanctuaries. Our main question to address was "how do others make it work?". Our purpose in doing so is to obtain indicators of what would be needed in terms of activities, budget and manpower to achieve the same (i,e, successful implementation) for the Yarari Sanctuary. Our review was based on both publicly available information and information provided by the management of the respective sanctuaries.

The first key observation is that without exception, the marine mammal sanctuaries defined highly ambitious goals and objectives even though the funding that would be needed to really sort effect on all points listed was characteristically limited. So there seems to be a big mismatch between goal setting and implementation. Even though there is much to be said in being complete and extensive, in the case of the Yarari management implementation plan we recommend to aim for practical steps as part of a phased implementation plan to achieve measurable but realistic progress under the reigning constraints.

The review allowed several more key insights. Firstly, from our analysis it is clear that the situations under which marine mammals sanctuaries have been defined and are being managed can differ greatly. Table 11 presents a brief overview of key management parameters from which to distil insights applicable to Yarari. The sister sanctuaries differ greatly in such parameters as size, cetacean density, the nature and intensity of threats to address, funding level and staffing. Nevertheless, it appears that adequate protection of cetaceans in sanctuary situations need not necessarily be very expensive (Table 11). 
Consequently, based on parallels drawn from good examples of function marine mammal sanctuaries for the Yarari Sanctuary, which is relatively small and has relatively low cetacean density (de Graaf et al. 2017) and low threat levels (this report), achieving adequate cetacean management and protection should neither be expensive or difficult. We suggest that two dedicated structural field support personnel added to the already existing management formation for an (additional) total budget of 150 $\mathrm{K}$ dollars represents sufficient added capacity to implement an effective cetacean conservation program for the present Yarari sector around Saba and the Saba Bank.

Most other sanctuary management units do not conduct their own research as this is expensive and requires specialized expertise. Indeed, as pointed out before by Debrot et al. (2011) in most parks around the world, monitoring activity only uses up a small part of the total park budget, at most only a few percent of total annual budget expenditures are dedicated to monitoring (and research) (Casanovas et al. 2014, IFG 2014a, IFG, 2014b, NPS 2008, 2009).

For these reasons for the Yarari, we also suggest leaving the activity of scientific research largely in the hands of scientific institutes (as is currently the case) and limiting research-related activity largely to some basic record keeping on strandings and observations and provide the logistical support of research led by visiting scientists. As most analysis and writing (i.e. actual costs) takes place by others well after the fieldwork is completed, basic support of visiting scientists can yield much knowledge based on a small and temporary logistical support. In other words, logistic support of visiting scientists is an activity that provides high leverage to science output and the generation of new knowledge(leverage factor of 1:10). Structural research is certainly needed and can be contributed to by sanctuary management but does not form part of the core responsibilities of sanctuary management.

Enforcement can also be a very expensive activity for sanctuary management. Only Stellwagen uses its own relatively extensive enforcement due to the combined high concentration of both cetaceans and fishing taking place in sanctuary waters. The other three sister sanctuaries largely rely on the deterrent effect of stringent legislation to limit the need for enforcement and collaboration with other enforcement units such as the coast guard to effectively implement enforcement (Table 11).

Enforcement can be strengthened considerably based on real-time access to AIS data.

Table 11 Synopsis of management review of functioning western Atlantic marine mammal sanctuaries and deduced recommendations for marine mammal budget and manpower for Yarari (in yellow).

\begin{tabular}{|c|c|c|c|c|c|c|c|c|c|c|}
\hline Mar. Mamm. Sanctuary & Country & Area $\left(\mathrm{km}^{2}\right)$ & $\begin{array}{l}\text { Cetacean } \\
\text { density }\end{array}$ & User density & Key threats & Own research? & $\begin{array}{l}\text { Own } \\
\text { enforcement? }\end{array}$ & Staffing (fte) & $\begin{array}{l}\text { Annual Budget } \\
\text { (USS equivalent) }\end{array}$ & Effective? \\
\hline $\begin{array}{l}\text { Bermuda Marine Mammal } \\
\text { Sanctuary }\end{array}$ & Bermuda & 464,993 & low & low & $\begin{array}{l}\text { collisions } \\
\text { entanglement } \\
\text { pollution }\end{array}$ & no & in collaboration & $9 * 0.05=0.45$ & 29,000 & yes \\
\hline $\begin{array}{l}\text { Marine Mammal } \\
\text { Sanctuary of the } \\
\text { Dominican Republic }\end{array}$ & Dominican $R$. & 50,000 & high & high & $\begin{array}{l}\text { entanglement } \\
\text { pollution } \\
\text { collisions } \\
\text { disturbance } \\
\text { climate change }\end{array}$ & no & other parties & $1+$ volunteers & $? ?$ & ? Probably \\
\hline AGOA & France & 143,256 & moderate? & moderate? & $\begin{array}{l}\text { collision pollution } \\
\text { disturbance noise } \\
\text { incidental catch } \\
\text { litter }\end{array}$ & project-based & in collaboration & 4 & 400,000 & unknown \\
\hline Yarari (windward) & $\begin{array}{l}\text { Dutch } \\
\text { Caribbean }\end{array}$ & 23,000 & low & low & all threats low & $\begin{array}{l}\text { limit to visiting } \\
\text { scientist support }\end{array}$ & in collaboration & add 2 & add 100,000 & $\begin{array}{l}\text { expected } \\
\text { to be } \\
\text { effective }\end{array}$ \\
\hline
\end{tabular}

Conclusions from the management review

- In terms of needed personnel, two additional field support personnel are sufficient to implement an effective cetacean conservation program for the Yarari Sanctuary.

- In terms of finances, this amounts to an added annual budget of US\$150K (including material costs).

- Logistical support to visiting marine mammal scientists (incl. their students and interns) provides high research leverage but management should refrain from conducting costly research itself. 
Practical support of marine mammal law enforcement ("eyes and ears", filing charges, testifying in court) should be provided to the coastguard and the police but management should refrain from conducting costly primary patrolling and arrests. 


\section{$4 \quad$ Key opportunities for regional cooperation on marine mammals}

\subsection{Introduction}

In this section we highlight a number of regional initiatives in which help foster international cooperation and coherency. First, each of the initiatives are described separately. A short summary and conclusions (4.2) describes the key opportunities.

\subsection{Regional initiatives}

\subsubsection{Specially Protected Areas and Wildlife (SPAW) Protocol}

The Specially Protected Areas and Wildlife (SPAW) Protocol, born out of the Convention for the Protection and Development of the Marine Environment of the Wider Caribbean Region (Cartagena Convention), came into force in 2000 and is now the only regional biodiversity agreement for the advancement of the conservation and protection of the marine environment in the Wider Caribbean Region. As such, it forms an important framework for collaboration on cetacean conservation and management. Countries that have ratified the SPAW Protocol are shown in Figure 21.

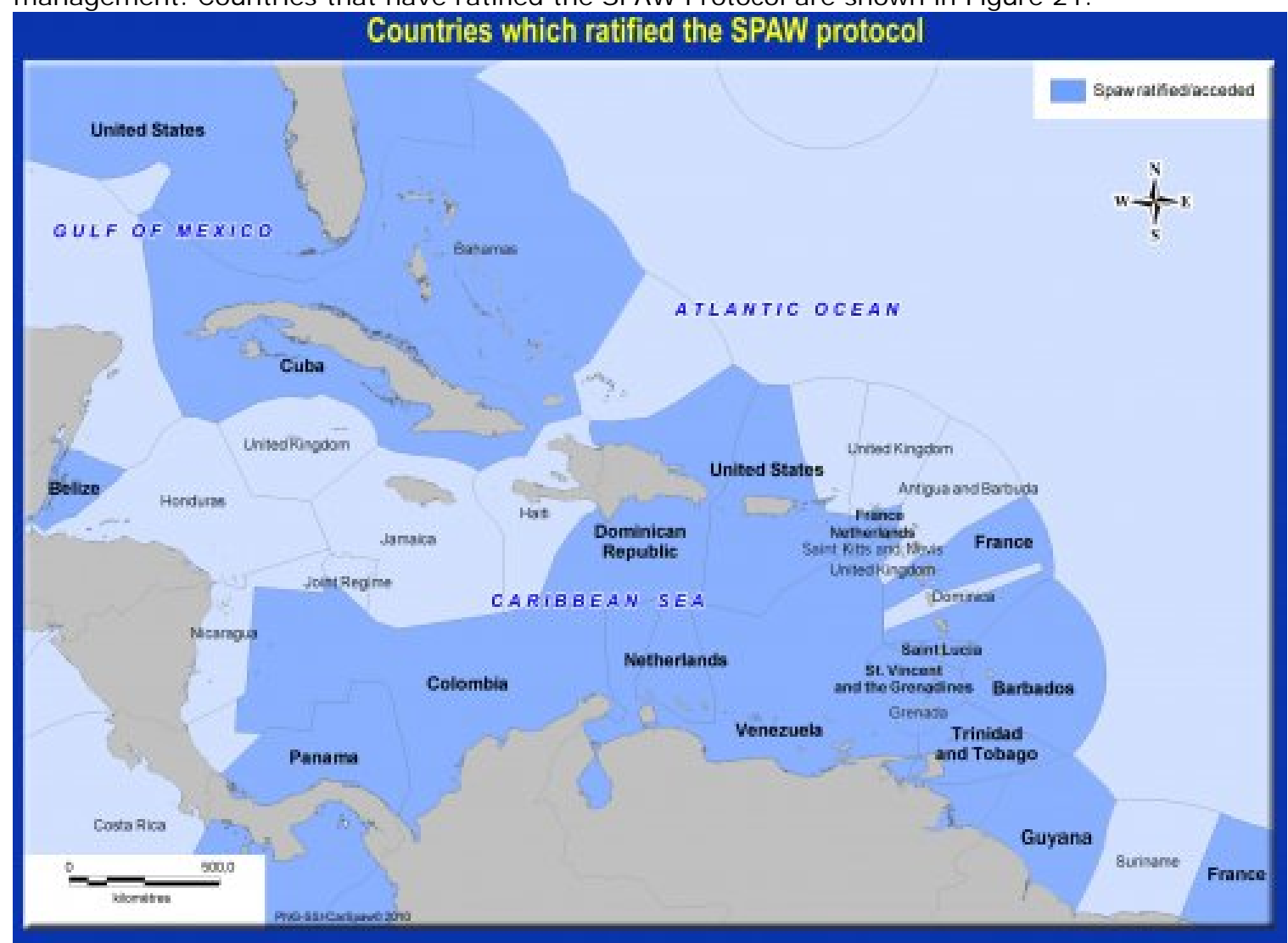

Figure 21 Countries which ratified the SPAW protocol (source: http://www.car-spawrac. org/?lang=en).

\subsubsection{The Wider Caribbean Region Marine Mammal Action Plan}

In the context of the SPAW Protocol, governments have agreed on the need to develop a regional management plan for the conservation of marine mammals. In 2008, UNEP published the action plan for the conservation of marine mammals (MMAP) in the Wider Caribbean Region (UNEP, 2008). The 
goal of the MMAP is to assist participating governments in the region in their efforts to develop and improve marine mammal conservation policies and practices.

Priorities for implementation of the MMAP have been established and are regularly updated (UNEP, 2012). The MMAP consists of five target areas: increased scientific knowledge; enhanced public understanding; protective measures; policy development and improvement of law and its application. The long-term objectives are (UNEP, 2008):

- Conservation and recovery of all marine mammal species and populations, and protection of their habitats in the region (e.g. feeding, breeding, and calving grounds, movement corridors, etc.).

- Establishment of regional cooperation programmes to increase scientific, technical, and educational exchange among relevant national, regional, and international organizations.

The MMAP focuses on the following two broad aims (UNEP, 2008):

- Management of human interactions and use

o I dentify and assess all significant threats to marine mammals (in general and as species and populations);

o Address and mitigate human-related threats to marine mammals and the viability of their populations and habitats;

o Manage stranded marine mammals;

o Manage the holding and taking of marine mammals; and,

o Address risks and uncertainty when making decisions, and ensure that a precautionary approach is taken.

- $\quad$ Species protection

o Improve understanding of the biology of all marine mammals, especially those that are threatened currently or that have been affected by past or present human activities;

o Maintain, and where appropriate, seek to restore, the distribution, abundance and diversity of marine mammals in the WCR;

o Protect habitats in the WCR that are "significant" to marine mammals; and,

o Seek to ensure that there are self-sustaining populations of all marine mammals throughout their natural range).

\subsubsection{The Sister Sanctuary Program}

In 2006, Stellwagen Bank National Marine Sanctuary established the Sister Sanctuary Program for developing strategic, science-based "sister sanctuary relationships" to insure the "protection of our shared population of humpback whales outside of U.S. borders", with specific focus on international breeding and mating grounds in the Caribbean and on the principal migration corridors. The Sister Sanctuary Agreement between the U.S. and the other states was developed to protect both ends of the migration corridor of the humpback whales (Figure 22) from the West Indies to one of their feeding grounds, the U.S. Stellwagen Bank National Marine Sanctuary, a mere 3,000 miles apart, as well as to protect the stop-over sites. The whales travel between the rich feeding grounds of Stellwagen Bank before heading south to the warmer waters of the Caribbean to give birth to their calves between December and April. The reason behind the partnership is the protection of the existing humpback whale population to ensure its survival in the U.S. waters off the coast of Massachusetts (currently counting around 900 individuals). 


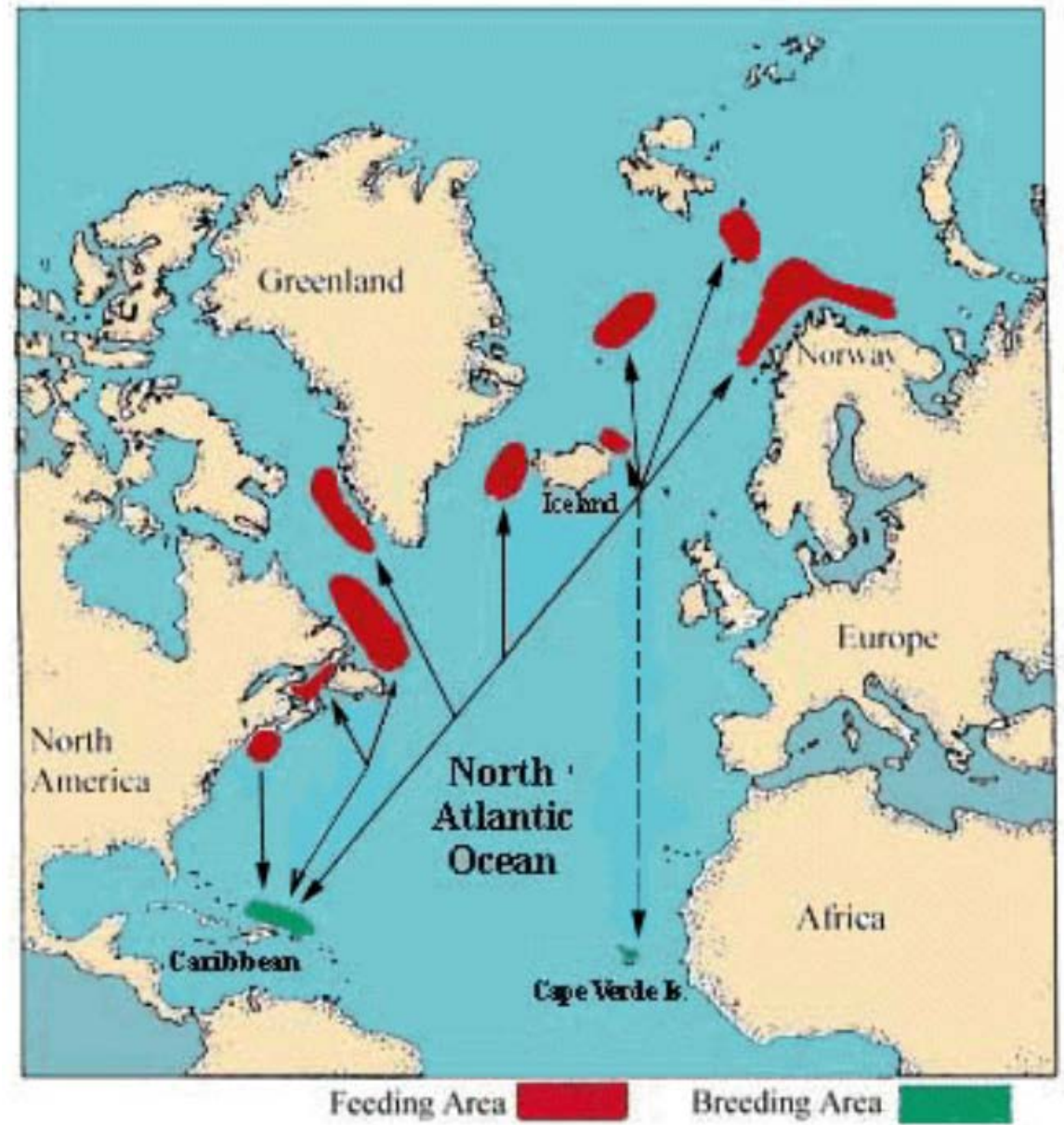

Figure 22 Migration route of the North Atlantic Humpback Whale population (Source: Stellwagen Bank National Marine Sanctuary Web Group, 2016). (The Caribbean humpback calving area likely was much larger than as shown on this map. Today it may still include the Saba Bank. There is also considerable evidence for a large former calving subpopulation located in the southern Caribbean; Stevick et al. 2014).

Over the past ten years, the Sister Sanctuary Program has expanded protection of North Atlantic humpback whales from $2191 \mathrm{~km}^{2}$ to $699,440-\mathrm{km}^{2}$, making it one of the largest coordinated marine mammal conservation areas in the world (see Figure 23). It includes Stellwagen Bank National Marine Sanctuary (US), Agoa (French Antilles), Yarari (Caribbean Netherlands), the Domincan Republic and Bermuda's Marine Mammal Sanctuaries. They collaborate together with UNEP's Specially Protected Areas and Wildlife (SPAW) Programme, with the mission to protect North Atlantic humpback whales and their ocean habitat. Activities in the Sister Sanctuary agreement will be conducted subject to the availability of funds (NOAA and the Government of Bermuda, 2012).

\subsubsection{Regional efforts directed towards protection of marine mammals in the Wider Caribbean}

\section{Marine mammal watching}

In 2011 a workshop on marine mammal watching operations was held in Panama City, Panama. The workshop was held in three languages and hosted 39 participants from 23 countries from the Wider Caribbean (WCR) and Argentina. The participants included tour operators and/or government representatives from the WCR (UNEP, 2012). The workshop produced a set of overarching principles for marine mammal watching, guidelines for responsible marine mammal watching, a template for the standardization of data collection, and a set of recommendations (UNEP, 2011). These principles, guidelines, standards and recommendations should also be considered within the development of the Yarari Sanctuary management plan. 


\section{Ship strikes}

In 2014 a ICW-SPAW workshop to address collisions between marine mammals and ships in the Wider Caribbean was held. It was recommended that existing (and any future) Sanctuaries in the region enter into a partnership network agreement and that it (ICW-SPAW, 2014):

- develops and shares expertise for expanded surveys and telemetry to understand inter-island movements and habitat use of migratory and resident populations of whales, in particular as it relates to shipping and strikes;

- continues to share educational materials, especially on ship strikes, where appropriate;

- $\quad$ promotes the sharing that photo-id catalogues are shared between networks and contributed to central catalogues where available (i.e. the North Atlantic Catalogue).

\section{Marine spatial planning for marine mammal corridors}

In keeping with the objectives of the SPAW Protocol, its MMAP, and the Programme of Work for Protected Areas under the Convention of Biological Diversity (CBD), the Government of Spain and UNEP have developed a partnership in support of LifeWeb, which includes a Project: "Broad-scale Marine Spatial Planning of Marine Mammal Corridors and Protected Areas in Wider Caribbean and Southeast \& Northeast Pacific". The project was launched in 2010 to assist countries develop and apply cross-sectoral ecosystem approaches to management of areas and the protection of marine mammals in both regions (Figure 5). Activities include mapping of critical marine mammal habitats and regional-scale migration routes, as well as of socioeconomic information on human activities to promote broad-scale spatial planning of marine mammal corridors and critical habitats. The Government of the Netherlands Antilles participated as partner in this project. The Caribbean Netherlands was also represented and participated in the project (pers. comm. A.O. Debrot).

\section{Marine Mammal Protection (1)}

Sanctuaries and protected areas

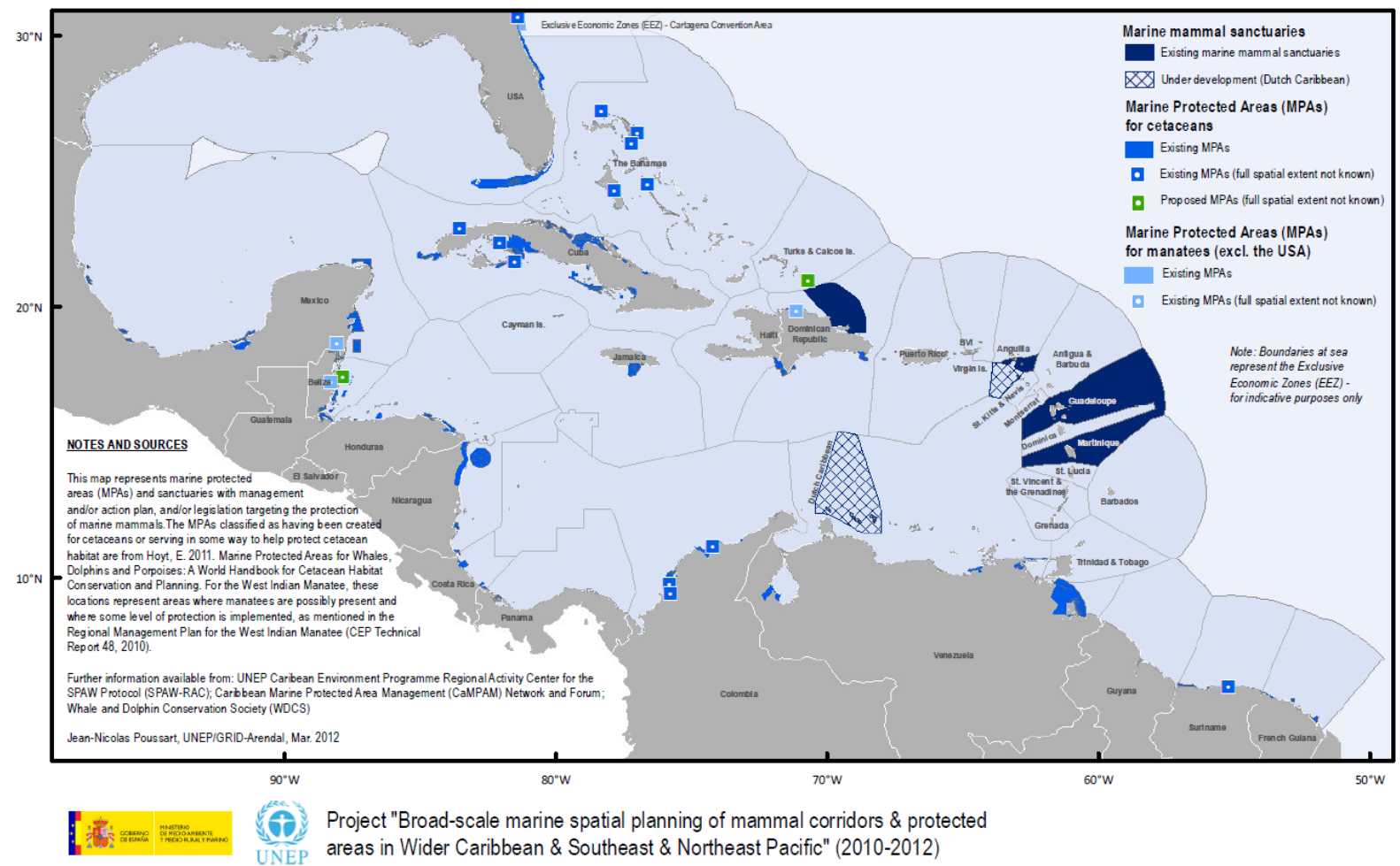

Figure 23 Marine mammal sanctuaries in the Wider Caribbean Region (http://www.car-spawrac.org/?-Maps-and-reports). Note: this figure presents an ideal version of the Yarari Sanctuary boundaries (indicated as 'under development'). In its current realisation the southern part of Yarari Sanctuary is considerably smaller than its ultimate potential size as it currently does not include the EEZs of Aruba or Curaçao but only the EEZ of Bonaire), see Figure 1.

\section{Carib tails humpback whale migration data collection}

Carib Tails (http://www.caribtails.org/) is an international citizen science effort collecting migration data on the population of humpback whales in the region between the U.S. Stellwagen Bank National 
Marine Sanctuary off the coast of Massachusetts and its sister sanctuaries across the Caribbean (among which the Dutch Caribbean, see the section above on "The Sister Sanctuary Program"). Yachters and sailors are invited to help scientists track the movements of endangered humpback whales.

\subsection{Summary and conclusions}

In this section we highlight a number of regional initiatives in which help foster international cooperation and coherency. As explained before, due to the transboundary nature of most marine mammal stocks, broader networks of cooperating sanctuaries and corridor areas are essential to effective long-term cetacean conservation. Participation in a number of international initiatives will form an essential part of the Yarari management implementation. The regional initiatives and their opportunities for the Yarari management are summarized in the table below.

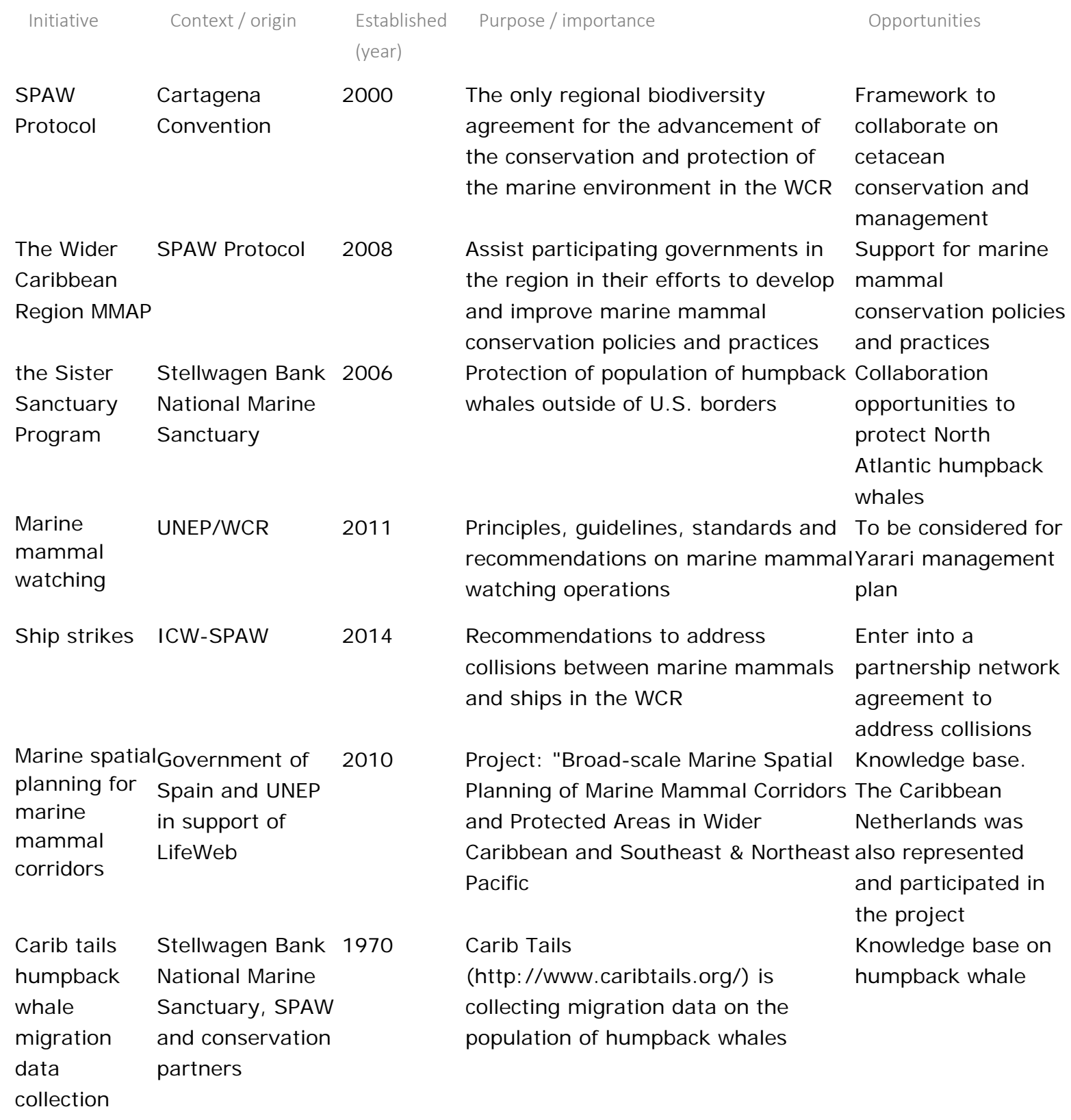




\section{$5 \quad$ Structuring and prioritizing marine mammal goals and objectives: an expert consultation}

\section{$5.1 \quad$ Introduction}

A key part of this assignment was to help explore what key goals and objectives would need to be defined for the Yarari Sanctuary marine mammals. Setting such priorities is a very important activity and is also the first step in determining what is required in terms of institutional and legal instruments, resources and facilities. Of course, not all goals and objectives may need to be, or must even preferentially, addressed by sanctuary management. Some key goals and objectives may in fact best be entrusted to, or conducted in cooperation with, more qualified partners (for instance, specialistic aspects of enforcement or research).

\subsection{Survey of expert opinions}

To develop priority goals and objectives for the new Yarari Marine Mammal Sanctuary, a brief survey questionnaire was set-up (Annex 3 ). The strategic sanctuary plan of the US National Marine Fishery Service (NOAA, 2005) was used as a model for defining potential goals and objectives.

The survey questionnaire was sent to key conservation NGOs and policy officers on all islands of the Dutch Caribbean and The Netherlands and to a number of key Western-North and Central Atlantic marine mammal sanctuaries for input. As experienced Wageningen Marine Research internal Caribbean cetacean specialists, questionnaires were also filled by Dr. A.O. Debrot and Dr. M. Scheidat.

\section{$5.3 \quad$ Results}

There were nine respondents resulting in eight contributions/completed questionnaires (Table 12). 
Table 62 Respondents to the goals and objectives survey.

\begin{tabular}{|c|c|c|}
\hline Name & Function & Organisation \\
\hline Paul C. Hoetjes & Policy Coordinator Nature & $\begin{array}{l}\text { Ministry of Economic Affairs (EZ), National Office for the } \\
\text { Caribbean Netherlands (RCN) }\end{array}$ \\
\hline Tadzio Bervoets & Manager & Nature Foundation St Maarten \\
\hline Jens Odinga & $\begin{array}{l}\text { Saba Bank National Park } \\
\text { Officer }\end{array}$ & $\begin{array}{l}\text { Saba Bank Management Unit / Saba Conservation } \\
\text { Foundation }\end{array}$ \\
\hline Dr. Nathalie Ward & $\begin{array}{l}\text { Sister Sanctuary Program and } \\
\text { Sanctuary Advisory Council } \\
\text { Coordinator }\end{array}$ & Stellwagen Bank National Marine Sanctuary \\
\hline Romain Renoux & $\begin{array}{l}\text { Head of Regional cooperation, } \\
\text { BEST Caribbean Hub } \\
\text { Coordinator, Agoa } \\
\text { Representative }\end{array}$ & $\begin{array}{l}\text { La Réserve naturelle de Saint-Martin management } \\
\text { association }\end{array}$ \\
\hline Dr. Sarah Manuel & $\begin{array}{l}\text { Senior Marine Conservation } \\
\text { Officer }\end{array}$ & $\begin{array}{l}\text { Department of Environment and Natural Resources } \\
\text { Marine Management Section }\end{array}$ \\
\hline Dr. Ingvild Harkes & $\begin{array}{l}\text { Sr Marine Advisor Oceans \& } \\
\text { Coasts Programme }\end{array}$ & WWF-Netherlands \\
\hline Dr. Meike Scheidat & Research scientist & Wageningen Marine Research \\
\hline Dr. Dolfi Debrot & Research scientist & Wageningen Marine Research \\
\hline
\end{tabular}

A few contributors stressed the importance of the underlying connections of objectives in their response. Even more, the priority of objectives is dependent on what "phase" the development of the sanctuary is, i.e. the emphasis on either research, science, education or policy will differ in time according to the specific implementation phase of the sanctuary (pers. comm. Nathalie Ward, NOAA Federal).

Although an objective could be very important it does not mean that it should be a first priority. This depends on the state of development of the sanctuary, such as the level of organisation, available funds, and the degree of knowledge, the legal status and specific threats to cetaceans of the sanctuary. An important starting point for a sanctuary management plan is to possess basic institutional capacity, as schematically presented in Figure 24. Some institutional capacity is an essential precondition for any functionality. The diagram shows the interconnectedness between the goals and that you cannot choose one goal above the other without compromising all key goals for management implementation. Everything begins and ends with institutional capacity, which has been recognized as the most serious bottleneck for environmental management in the Caribbean since the 1970 and which it still is today. In view of the complex nature of marine mammal conservation the next most important goal is the goal of broad cooperation with other parties. Finally, scientific understanding and awareness as key goals as made possible by means of both inherent and joint effort, sets the basis for sustainable management and protection of cetaceans. 


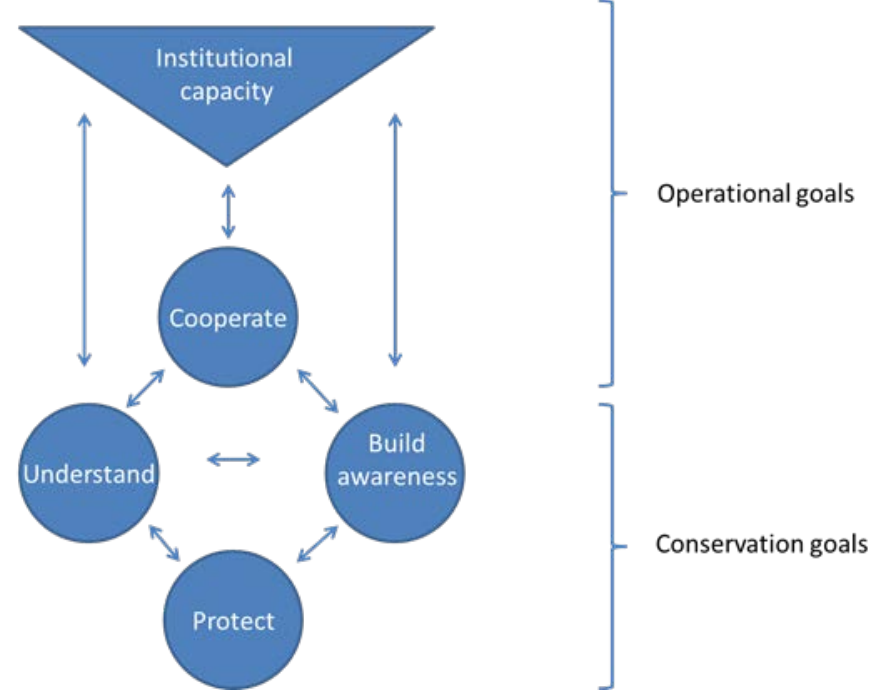

Figure 24 Relationships between five major goal areas for sanctuary management.

Based on the results of the questionnaire (Table 13), the most important goals for the Yarari Sanctuary (i.e. all respondents considered these goals essential or important) according to the consulted experts were to:

- (protect) Manage the Yarari Sanctuary to maintain, protect, restore and enhance natural habitats and populations of cetaceans, and to;

- (study) Investigate and enhance the understanding of marine mammals in and around the Yarari Sanctuary.

All goals were considered needed for the Yarari Sanctuary with the exception of one respondent who considered goal "f" (facilitate compatible human use of the Yarari Sanctuary) unimportant. Besides the two main goals unanimously considered as essential/important, other goals ranked in order of importance (high to low) were as follows:

- Build, maintain, and enhance the operational capability and infrastructure necessary to achieve key Yarari marine mammal conservation goals;

- Work with the international and inter-island community to strengthen marine mammal conservation in the Caribbean region;

- Expand and strengthen sanctuary management throughout the Dutch Caribbean;

- Enhance nation-wide public awareness, understanding, and appreciation of marine mammals;

- Facilitate compatible human use of the Yarari Sanctuary. 
Table 13 I mportance of the management goals for the Yarari Sanctuary marine mammals, as indicated by the results of the questionnaire $(H=$ High priority, essential; $M=$ Medium priority, important but not essential; $L=$ Low priority, complementary; $N=$ Not really needed). Numbers indicate the number of respondents that filled in that category. Halves are used when respondents used mixed categories, e.g. "M-H".

\begin{tabular}{|c|c|c|c|c|}
\hline $\begin{array}{l}\text { a) Manage the Yarari Sanctuary to maintain, protect, restore and enhance natural habitats and } \\
\text { populations of cetaceans. }\end{array}$ & 0 & 0 & 1 & 7 \\
\hline $\begin{array}{l}\text { b) Build, maintain, and enhance the operational capability and infrastructure necessary to achieve key } \\
\text { Yarari marine mammal conservation goals. }\end{array}$ & 0 & 1 & 1 & 6 \\
\hline d) Expand and strengthen sanctuary management throughout the Dutch Caribbean. & 0 & 1 & 1,5 & 3,5 \\
\hline e) Investigate and enhance the understanding of marine mammals in and around the Yarari Sanctuary. & 0 & 0 & 1 & 7 \\
\hline f) Facilitate compatible human use of the Yarari Sanctuary. & 1 & 1 & 2,5 & 2,5 \\
\hline $\begin{array}{l}\text { g) Work with the international and inter-island community to strengthen marine mammal conservation in } \\
\text { the Caribbean region. }\end{array}$ & 0 & 1 & 2 & 4 \\
\hline
\end{tabular}

As discussed before, when prioritising the goals the interconnectedness should be considered. Therefore, the suggested goals for the Yarari Sanctuary have been structured according to the iterative inter-relationship between clusters of priorities (Figure 25).

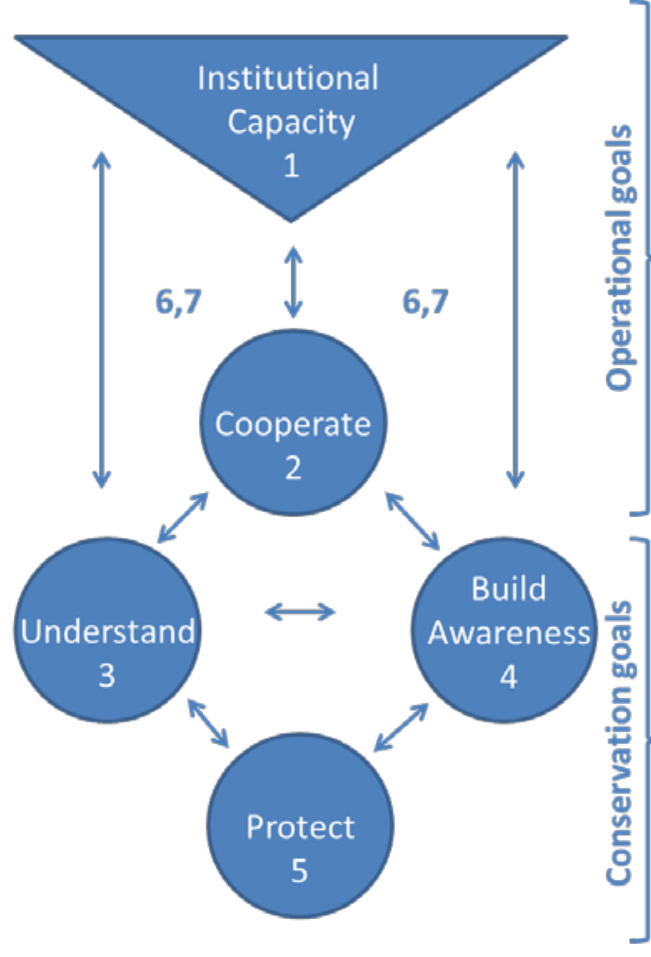

\section{Operational goals}

1. Build, maintain, and enhance the operational capability and infrastructure necessary to achieve key Yarari marine mammal conservation goals

2. Work with the international and interisland community to strengthen marine mammal conservation in the Caribbean region

\section{Expand and strengthen sanctuary management throughout the Dutch Caribbean}

7. Facilitate compatible human use of the Yarari sanctuary

\section{Conservation goals}

3. Investigate and enhance the understanding of marine mammals in and around the Yarari reserve

4. Enhance nation-wide public awareness, understanding, and appreciation of marine mammals

5. Manage the Yarari sanctuary to maintain, protect, restore and enhance natural habitats and populations of cetaceans

Figure 17 Operational and conservation goals suggested for the Yarari Sanctuary, showing the relationships and key phases of priority development.

The second part of the questionnaire was to categorise potential objectives for each goal. Results are presented in Table 14. 
Table 14 I mportance of objectives for the goals suggested for the Yarari Sanctuary, according to the results of the questionnaire $(\mathrm{H}=$ High priority, essential; $M=$ Medium priority, important but not essential; $\mathrm{L}=$ Low priority, complementary; $\mathrm{N}=$ Not really needed). Numbers indicate the number of respondents that filled in that category. Halves are used when respondents used mixed categories,

e.g. "M-H".

Goal: Manage the Yarari Sanctuary to maintain, protect, restore and enhance natural habitats ano populations of cetaceans

\begin{tabular}{|c|c|c|c|c|}
\hline Objectives & $\mathbf{N}$ & $\mathbf{L}$ & M & H \\
\hline Prepare sanctuary management plans & 0 & 0 & 1 & 7 \\
\hline $\begin{array}{l}\text { Conduct and maintain routine contingency planning to preserve and restore the integrity of sanctuary } \\
\text { ecosystems }\end{array}$ & 1 & 0 & 3 & 3 \\
\hline Develop and maintain programs and partnerships for enforcement & 1 & 0 & 3,5 & 3 , \\
\hline Review and evaluate the Yarari's effectiveness at site, regional, and national levels & 0 & 2 & 3 & 3 \\
\hline Anticipate, prevent and mitigate threats to resources & 0 & 1 & 3 & 4 \\
\hline Assess changes affecting Yarari and evolve management strategies accordingly & 0 & 2 & 3,5 & 2, \\
\hline \multicolumn{5}{|c|}{$\begin{array}{l}\text { Goal: Build, maintain, and enhance the operational capability and infrastructure necessary to achieve key } \\
\text { Yarari marine mammal conservation goals }\end{array}$} \\
\hline Objectives & $\mathbf{N}$ & $\mathbf{L}$ & M & $\mathbf{H}$ \\
\hline Cultivate a highly qualified and dedicated staff for Yarari & 0 & 1 & 1 & 6 \\
\hline $\begin{array}{l}\text { Implement a regional management structure to integrate Yarari into region-based marine mammal } \\
\text { networks }\end{array}$ & 0 & 2 & 2,5 & 3, \\
\hline Support and expand the volunteer programs for support and awareness & 0 & 2 & 3 & 2 \\
\hline $\begin{array}{l}\text { Maintain, and enhance the facilities, equipment, and other infrastructure } \\
\text { operations }\end{array}$ & 0 & 0 & 4 & 4 \\
\hline
\end{tabular}
operations

Goal: Enhance nation-wide public awareness, understanding, and appreciation of marine mammals

Objectives

Provide education opportunities that will reach a diverse national population

Implement outreach programs to increase awareness of marine mammals and Yarari

$0 \quad 0 \quad 116$

Establish partnerships to supplement the Yarari's education and outreach efforts

$0 \begin{array}{lll}0 & 0 & 2\end{array}$

\section{Goal: Build and strengthen Yarari Sanctuary management}

\section{Objectives}

Facilitate identification of potential expansion, in coordination with key stakeholders

\section{Objectives}

Expand observing systems and monitoring efforts within and near Yarari to fill important gaps in the $\begin{array}{llllll}0 & 0 & 0\end{array}$ knowledge of marine mammals and potential threats

\begin{tabular}{lllll} 
Support directed research activities that support management decision-making & 3 & 5 & 0 & 3 \\
\hline Develop audio visual products for awareness & 0 & 3,5 & 2,5 & 2
\end{tabular}

Goal: Facilitate compatible human use of the Yarari Sanctuary

\section{Objectives}

Work closely with partners to assess and manage human use of sanctuary resources

Create, operate, and support community-based sanctuary advisory councils

$1 \quad 0 \quad 1 \quad 5$

Consult and coordinate with agencies and partners conducting activities in or near Yarari

Use other tools such as policy development, permitting, and regulatory review and improvement to help guide human use of sanctuary resources

Create and support programs and strategies to work with island inhabitants

Goal: Work with the international and inter-island community to strengthen marine mammal conservation in the Caribbean region

\begin{tabular}{|c|c|c|c|c|}
\hline Objectives & $\mathbf{N}$ & L & M & H \\
\hline $\begin{array}{l}\text { Develop multilateral program relationships to interact with international partners to improve Yarari } \\
\text { management capacity }\end{array}$ & 0 & 0 & 2 & 6 \\
\hline $\begin{array}{l}\text { Investigate the use of international legal conventions and other instruments to help protect marine } \\
\text { mammals }\end{array}$ & 2 & 3 & 2 & 1 \\
\hline Cooperate with global research initiatives to improve the overall knowledge of marine mammals & 0 & 2 & 4 & 2 \\
\hline Make Yarari education and awareness programs accessible throu & 1 & 3 & 2 & 2 \\
\hline
\end{tabular}

Based on these results the goal-related objectives for the Yarari Sanctuary are here ranked in order of their importance as accorded to by the consulted experts (high to low): 
- Manage the Yarari Sanctuary to maintain, protect, restore and enhance natural habitats and populations of cetaceans

o Prepare sanctuary management plans

o Anticipate, prevent and mitigate threats to resources

o Develop and maintain programs and partnerships for enforcement

o Review and evaluate the Yarari's effectiveness at site, national, regional and (international) levels

o Conduct and maintain routine contingency planning to preserve and restore the integrity of sanctuary ecosystems

o Assess changes affecting Yarari and adapt management strategies accordingly

- Investigate and enhance the understanding of marine mammals in and around the Yarari Sanctuary

o Expand observing systems and monitoring efforts within and near Yarari to fill important gaps in the knowledge of marine mammals and potential threats.

o Support directed research activities that support management decision-making.

o Develop audio visual products for awareness

- Build, maintain, and enhance the operational capability and infrastructure necessary to achieve key Yarari marine mammal conservation goals

o Cultivate a highly qualified and dedicated staff for Yarari

o Maintain, and enhance the facilities, equipment, and other infrastructure required for conducting operations

o Implement a regional management structure to integrate Yarari into region-based marine mammal networks

o Support and expand the volunteer programs for support and awareness

- Work with the international and inter-island community to strengthen marine mammal conservation in the Caribbean region

o Develop multilateral program relationships to interact with international partners to improve Yarari management capacity

o Cooperate with global research initiatives to improve the overall knowledge of marine mammals

o Make Yarari education and awareness programs accessible through international efforts

o Investigate the use of international legal conventions and other instruments to help protect marine mammals

- Expand and strengthen sanctuary management throughout the Dutch Caribbean

o Develop and maintain interagency partnerships and collaborations, particularly with other national and international protected area and resource managers

o I I itiate, coordinate and participate in ecosystem-based and network initiatives.

o Facilitate identification of potential expansion, in coordination with key stakeholders

- Enhance nation-wide public awareness, understanding, and appreciation of marine mammals

o I mplement outreach programs to increase awareness of marine mammals and Yarari

- Establish partnerships to supplement the Yarari's education and outreach efforts

o Provide education opportunities that will reach a diverse national population

- Facilitate compatible human use of the Yarari Sanctuary

o Work closely with partners to assess and manage human use of sanctuary resources

o Consult and coordinate with agencies and partners conducting activities in or near Yarari

o Use other tools such as policy development, permitting, and regulatory review and improvement to help guide human use of sanctuary resources

o Create and support programs and strategies to work with island inhabitants

o Create, operate, and support community-based sanctuary advisory councils

In addition, the goals and objectives are categorised according to the management scheme presented in Figure 24. This enables us to assess the priority of each goal and objective according to their relationships and phases of development. Acknowledging that effective management starts with institutional capacity, the goals could be prioritised from top to bottom and the objectives from left to right. This means that conservation objectives related to a high priority goal are not considered as first 
logical steps. Instead, first the operational objectives should be initiated/established. Another consequence is that not all objectives related to conservation goals need to be built up from the operational goals. If conservation goals are supported by operational objectives these objectives could be considered a higher priority. It should also be noted that the structure for the implementation of goals and objectives is an iterative process, as schematically presented in Figure 25.

Table 15 Operational and conservation goals and objectives suggested for the Yarari Sanctuary, showing the relationships and phases of development. The first column presents the goals, categorised according to the management cycle (see also Figure 2) from top to bottom. The following columns present the objectives for each goal, also categorised according to the management cycle (from left to right).

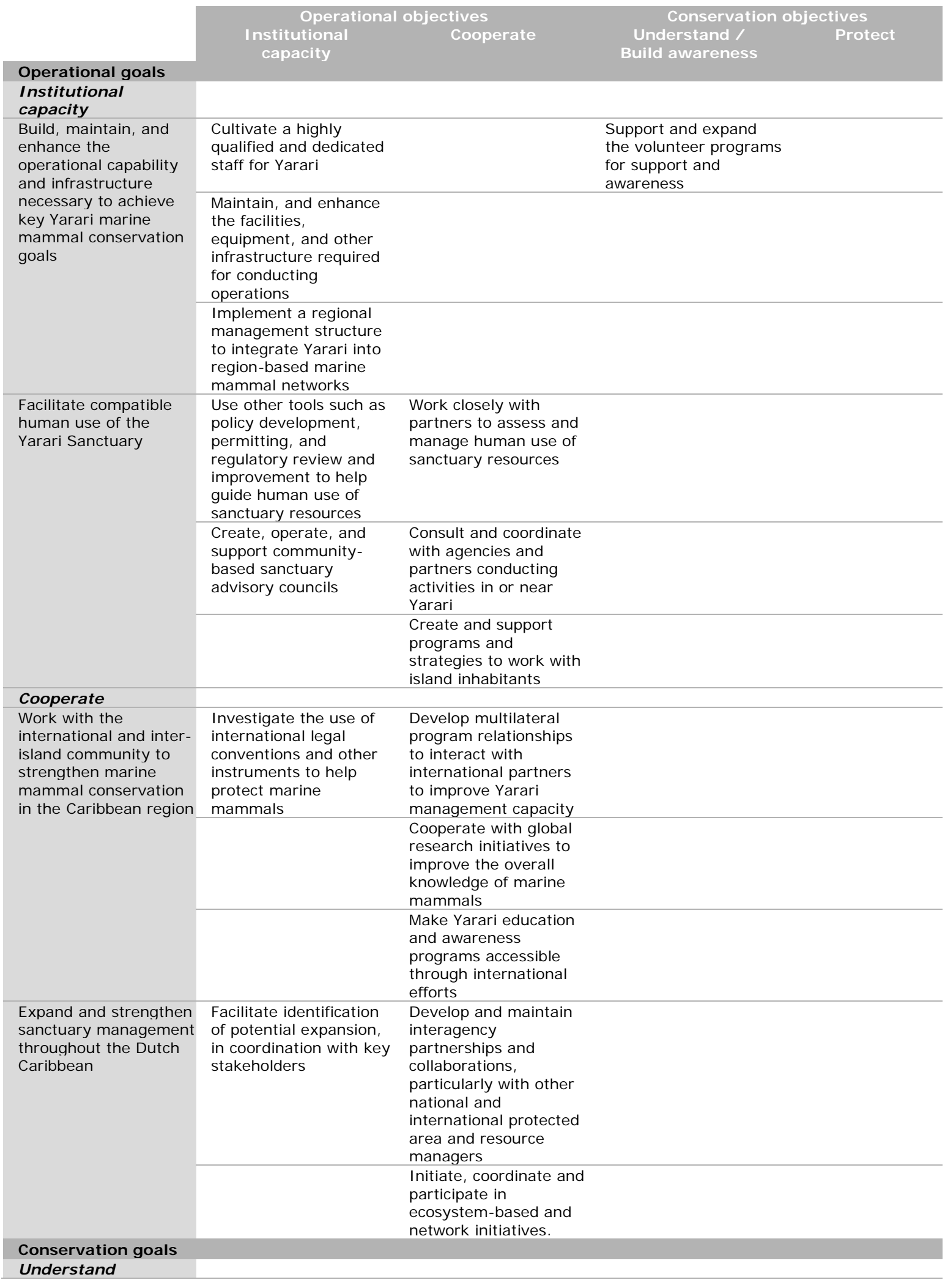




\begin{tabular}{|c|c|c|c|c|}
\hline & \multicolumn{2}{|c|}{ Operational objectives } & \multicolumn{2}{|c|}{ Conservation objectives } \\
\hline & $\begin{array}{l}\text { Institutional } \\
\text { capacity }\end{array}$ & Cooperate & $\begin{array}{l}\text { Understand / } \\
\text { Build awareness }\end{array}$ & Protect \\
\hline \multirow[t]{2}{*}{$\begin{array}{l}\text { Investigate and } \\
\text { enhance the } \\
\text { understanding of } \\
\text { marine mammals in } \\
\text { and around the Yarari } \\
\text { Sanctuary }\end{array}$} & $\begin{array}{l}\text { Support directed } \\
\text { research activities that } \\
\text { support management } \\
\text { decision-making }\end{array}$ & & $\begin{array}{l}\text { Expand observing } \\
\text { systems and } \\
\text { monitoring efforts } \\
\text { within and near Yarari } \\
\text { to fill important gaps in } \\
\text { the knowledge of } \\
\text { marine mammals and } \\
\text { potential threats }\end{array}$ & \\
\hline & & & $\begin{array}{l}\text { Develop audio visual } \\
\text { products for awareness }\end{array}$ & \\
\hline \multicolumn{5}{|l|}{ Build awareness } \\
\hline \multirow{2}{*}{$\begin{array}{l}\text { Enhance nation-wide } \\
\text { public awareness, } \\
\text { understanding, and } \\
\text { appreciation of marine } \\
\text { mammals }\end{array}$} & & $\begin{array}{l}\text { Establish partnerships } \\
\text { to supplement the } \\
\text { Yarari's education and } \\
\text { outreach efforts }\end{array}$ & $\begin{array}{l}\text { Implement outreach } \\
\text { programs to increase } \\
\text { awareness of marine } \\
\text { mammals and Yarari }\end{array}$ & \\
\hline & & & $\begin{array}{l}\text { Provide education } \\
\text { opportunities that will } \\
\text { reach a diverse national } \\
\text { population }\end{array}$ & \\
\hline \multicolumn{5}{|l|}{ Protect } \\
\hline \multirow[t]{2}{*}{$\begin{array}{l}\text { Manage the Yarari } \\
\text { Sanctuary to maintain, } \\
\text { protect, restore and } \\
\text { enhance natural } \\
\text { habitats and } \\
\text { populations of } \\
\text { cetaceans }\end{array}$} & $\begin{array}{l}\text { Prepare sanctuary } \\
\text { management plans }\end{array}$ & $\begin{array}{l}\text { Develop and maintain } \\
\text { programs and } \\
\text { partnerships for } \\
\text { enforcement }\end{array}$ & $\begin{array}{l}\text { Review and evaluate } \\
\text { the Yarari's } \\
\text { effectiveness at site, } \\
\text { regional, and national } \\
\text { levels }\end{array}$ & $\begin{array}{l}\text { Anticipate, } \\
\text { prevent and } \\
\text { mitigate threats to } \\
\text { resources }\end{array}$ \\
\hline & & & $\begin{array}{l}\text { Assess changes } \\
\text { affecting Yarari and } \\
\text { evolve management } \\
\text { strategies accordingly }\end{array}$ & $\begin{array}{l}\text { Conduct and } \\
\text { maintain routine } \\
\text { contingency } \\
\text { planning to } \\
\text { preserve and } \\
\text { restore the } \\
\text { integrity of } \\
\text { sanctuary } \\
\text { ecosystems }\end{array}$ \\
\hline
\end{tabular}

\subsection{General conclusions on priority goals and objectives}

- We here present a structured approach to priority setting in goals and objectives for the Yarari Marine Mammal sanctuary

- In doing so, we identify five main clusters of interrelated goals and objectives

- The goals and objectives considered, span both (immediate) operational and (ultimate) conservation levels of priority

- These can be expected to differ in perceived priority according to the implementation lifephase of a sanctuary, as well as according to other factors such as the level of knowledge available on and the nature of threats faced by the marine mammals of the sanctuary

- The most essential precondition for management is to establish a minimum level of institutional capacity

- Under structural conditions of resource limitation, the next key goal is to establish effective collaboration towards jointly achieving the higher management goals and objectives.

- Our review shows that marine mammal management plans typically contain an ambitious set of goals and objectives that can typically only marginally be addressed due to lack of funding. Copying these over for the Yarari gives little added value other than providing the longlist of potential ambitions.

- From the long-list of "important" objectives for each defined goal, it is clear that not all can ever be achieved simultaneously because of practical constraints to capacity. Hence, choices need to be made and a phased multi-year step by step implementation of key goals and objectives will be essential to optimal development of sanctuary management.

- Finally, moving forward in time, joint management capacity and implementation can be seen to tightly interrelated and to poses synergistic feedback loops that can be utilised towards further professionalization and the achievement of higher (conservation) goals. 


\section{An effective sanctuary governance and management structure model}

\subsection{Introduction}

Management implementation in small island settings can be very challenging. In the small island setting many practical matters that normally do not play a major role in large continental settings come into play to effectively hinder management implementation and effectiveness. Simple dependence on importing parts for a vessel or the illness of a key personnel member in a small management unit can totally ground all field operations for months. For the Caribbean region as a whole as well as the Dutch Caribbean islands, the lack of institutional capacity for policy and legislation development as well as implementation have long been recognized as the principal bottleneck to sustainable environmental management (ECLAC 1998). In their review on nature policy development and implementation in the Dutch Caribbean during the decade from 2001-2010, Debrot et al. (2011) conclude that the most serious constraint to policy development and implementation continues to be the lack of institutional capacity. Hence, establishing a minimum of institutional capacity is the bare minimum needed as a condition for implementation.

The good news is, that based on our review of the functioning of other marine mammal sanctuaries, management effectiveness can be obtained with only a modest annual personnel and budgetary commitment. Based on the performance of other functioning "benchmark" sanctuaries we indicate that a very modest staffing of two persons and an annual budget of US\$150 K should provide enough capacity for good management implementation (section 3.2) . The designated personnel should be composed of one practical field support person with technical boat skills and one person capable of contributing to both local and international policy and legislation initiatives.

The small size of nature management organizations in the Caribbean Netherlands argues against creating yet another small organization to separately address marine mammal issues. Instead, the pooling of resources with other initiatives is preferred, as long as an organizational structure is found that functions at the governance level. Such an organization is the so-called Saba Bank Management Unit, which is run as a separate unit within the Saba Conservation Organization on Saba.

\subsection{Saba Bank Management Unit (SBMU)}

The Yarari marine mammal and shark sanctuary comprises most of the EEZ waters of the Caribbean Netherlands. The EEZ waters of the Caribbean Netherlands by law fall under the full management responsibility of the national government of the Netherlands as stipulated in the Conservation Framework Act BES (Wet grondslagen natuurbeheer- en bescherming BES). The Management of the fisheries and biodiversity of both EEZ and TW is guided by the Committee for management of the Marine Biodiversity and Fisheries of the Dutch Caribbean EEZ (CMBF, aka EEZ Committtee), which includes delegates of all the islands as well as The Netherlands. The Saba Bank forms the centrepiece of the Yarari Sanctuary and is a designated marine protected area. Its management is currently being implemented by the SBMU and is reported to the EEZ Committee. If this the governance performance of this unit functions properly, then this would be a logical institution in which to invest any additional capacity. 
The Terms of Reference for the installation of the SBMU provides essential insight into the governance structure of this unit. As indicated, the SBMU forms a-separate unit funded by the Ministry of Economic Affairs and subcontracted to the Saba Conservation Foundation. The daily management is delegated to the Saba Conservation Foundation (SCF) which also overseen the Saba National Marine Park. A small steering group, consisting of the SCF Parks Manager, MinEZ and the island government, is responsible for the overall management and planning. The SBMU also reports to the steering group and the EEZ Committee. The steering group convenes at least twice a year to evaluate and direct the program. Every two years the program is evaluated externally. The budget is established annually by the steering committee and includes finances for staffing, monitoring equipment, office overhead, boat maintenance, research support and operational costs. The SCF Parks Manager oversees the budgeted expenditure and day-to-day management of the unit.

Based on confidential input from independent parties, this unit seems to function well at the governance level. Interviews (by A. O. Debrot) with the steering group members and the responsible Min EZ policy officer, confirms this overall impression. However, steering group member Paul Hoetjes, M.Sc., points out two major current hindrances to the actual performance of the SMBU. Firstly is the structural lack of personnel. The fact that there are only two personnel members indicates that any diving work on the Bank is currently impossible without external support because sea conditions on the Saba Bank dictate that the captain must always remain on board, whereas diving safety dictates the need for a minimum of two person-diving teams. The second major hindrance is that the current vessel, the "Queen Beatrix", is too short to smoothly address the typical choppy seas on the Saba Bank. The Queen Beatrix was launched in 2012 as patrol boat for the SBMU (Figure 18). The Queen Beatrix is sailing under the flag of Curaçao and has an overall length of $10 \mathrm{~m}$ and a beam of $3 \mathrm{~m}$.

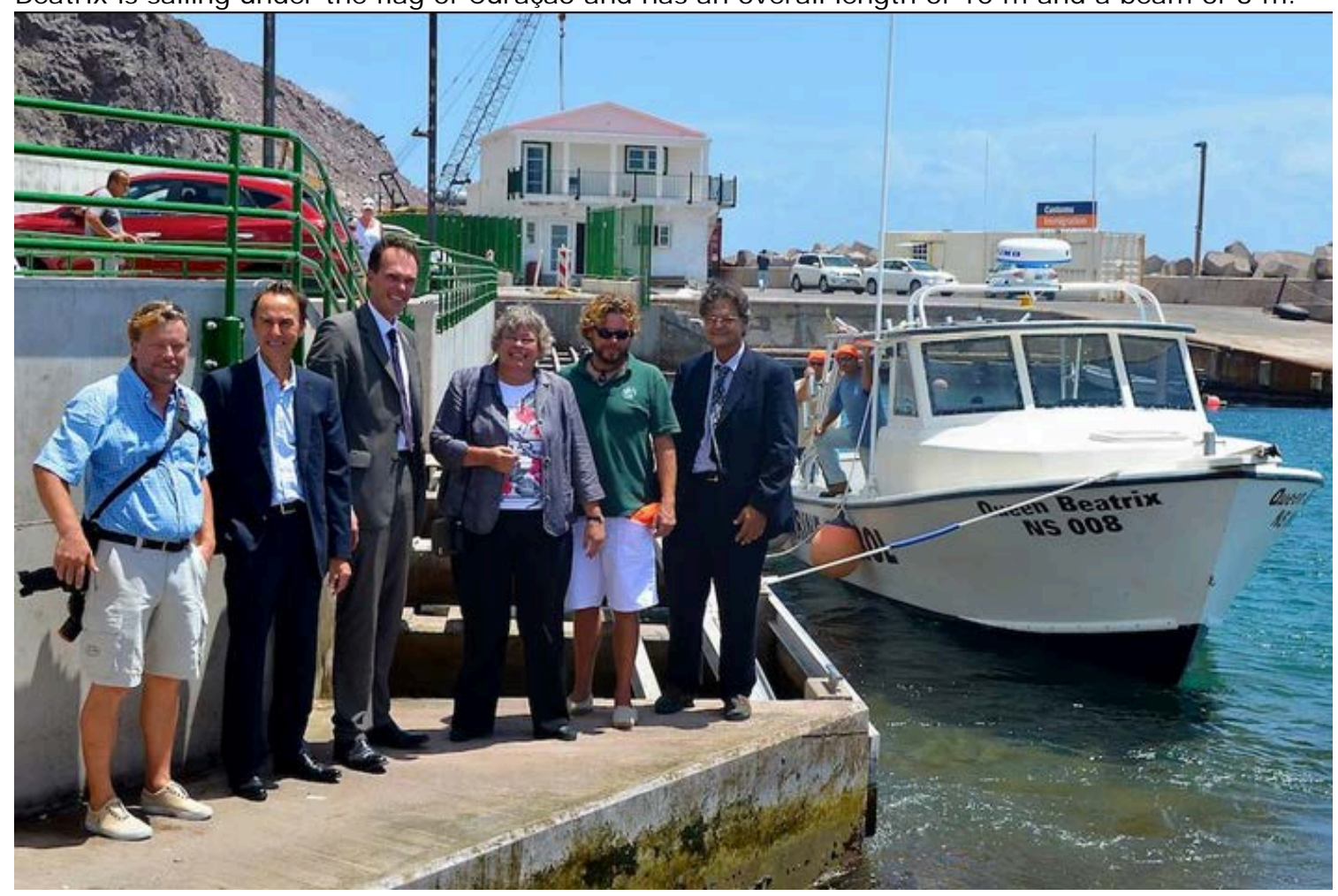

Figure 18 "The Queen Beatrix" Patrol Boat official launch during the National Park declarations on Saba (source: http://www.dcnanature.org/dutch-caribbean-parks-conservation-organizations-andspecial-guests-meet-in-Curacao/).

Kai Wulf, SCF director, stresses the value of expanding the Yarari Sanctuary to include St. Maarten and St. Eustatius. These islands appear to have been reluctant to participate until now because they only have a small part of the EEZ as compared to Saba. For this reason St. Maarten has also refrained from participation in the EEZ Committee. Nevertheless, in light of the ecotourism publicity value of a marine mammal sanctuary, there should be significant incentive for both islands to ultimately participate. With whale watching marked as a major growth industry of potential throughout the region (Hoyt and Hyengaard 2002, Vail 2005), both islands have much to gain by participating in 
Yarari, even though current cetacean densities are relatively low and sightings unpredictable (de Graaf et al. 2017). Therefore, the governance structure for the Yarari Sanctuary needs to be prepared to accommodate membership of St. Maarten and St. Eustatius, if and when those islands may wish to partake in Yarari. Even so, Yarari Sanctuary headquarters should be based on the island of Saba, not only based on the latter island's larger surface contribution to Yarari but also based on practical considerations of accessibility to the extended Yarari waters.

With respect to enforcement, Wulf stresses the need for cooperation with the Dutch Caribbean coastguard. One limitation to this is the fact that the coastguard is stationed in St. Maarten and only visits the bank incidentally. Therefore the SBMU plays a vital role as the "eyes and ears" of enforcement. Important institutional conditions for enforcement are a legal mandate for management of Yarari. As of yet, neither the SCF, SNMP nor the SBMU have any legal foundation for management or enforcement on the Saba Bank. Discussions could be undertaken with the Coastguard to establish a field station on Saba to facilitate a rapid response, which should include enforcement of fisheries regulations.

Given the large size of the area, critical for enforcement detection are the AIS installations on Saba. Saba National Marine Park has one installed on the roof of its offices but this installation has only limited reach due to its low position. The AIS installation on the top of Mt. Scenery by Rijkswaterstaat (RWS) (co-funded also by EZ) has much better reach and covers vessel movement over large stretches of the bank. However, access to the data is mired in complicated and tedious formalities via the Bureau Telecommunicatie in Curaçao. Faster and more direct access would be a boon for enforcement detections in the Yarari Sanctuary.

\subsection{Conclusions}

\subsubsection{Governance}

- The SBMU provides a suitable governance model for implementation of Yarari marine mammal management in the sector centred around Saba and the Saba Bank.

- It is based on a small team and hence capable of efficient decision making.

- Yarari governance structure should anticipate that other islands will want to join when it becomes clear that this will entail significant support to tourism development.

- Even so, Saba is the logical choice for basing the Yarari management headquarters.

- Parties could consider expanding the mandate of the SBMU to include implementation of Yarari marine mammal measures.

- In any case, the task should be subcontracted to an existing party so that resources can be effectively pooled for better overall functioning.

- A legal mandate should be designed and effected for effective management implementation.

\subsubsection{Logistics:}

- A somewhat larger vessel is needed to accompany the current SBMU vessel the Queen Beatrix for both comfort and safety while working on the bank.

- The recommended staffing with two dedicated Yarari personnel members should blend both technical boat handling skills and management skills.

- Access to the superior RWS AIS data needs to be arranged to sustain more effective enforcement and monitoring of ship traffic. 


\section{Synopsis of key priorities and action points towards implementation of sanctuary management for marine mammals}

\subsection{Governance}

- Use the SMBU governance model for Yarari management implementation

- Consider merging Yarari tasks into the SMBU to effectuate resource pooling to prevent management fragmentation ("versnippering" in Dutch)

\subsection{Legal resources}

- Design and implement a simple legal mandate for Yarari management

- Copy and implement international legal guidelines for whale watching

- Revise the Fishery Framework Act BES ("Visserijwet besluit BES") or draft a Decree ("Regeling") under the Nature Conservation Framework Act BES ("Wet Grondslagen Natuurbeheer en-bescherming, WGN") to forbid all forms of pelagic longline and purse seine fishing in Yarari waters (for both marine mammals but especially for sharks)

- Devise and implement legal measures and guidelines to protect Yarari from anthropogenic noise pollution.

\subsection{Finances}

- Based on the review of functioning sanctuaries, and current stressor levels, a basic annual budget of US\$150 K will be sufficient to implement satisfactory marine mammal conservation.

- $\quad$ Focus expenditures on management development, outreach and international cooperation.

- Limit expenditures on costly enforcement and research. Participation in these activities should principally be limited to essential monitoring and practical support of collaborating parties.

\subsection{Personnel and logistics}

- Based on the review of functioning sanctuaries, two (additional) personnel members are sufficient to effectuate adequate Yarari management

- The combined personnel should include both technical and boat handling skills as well as management development skills for effective local and international policy development and cooperation

- Saba island is the logical choice for basing Yarari headquarters

- A larger vessel (than the Queen Beatrix) is needed for safer and more effective operation in Yarari waters 


\subsection{Management priorities}

- Aim for sanctuary expansion to include St. Maarten and St. Eustatius marine waters, and ultimately also Curaçao and Aruba EEZ waters

- Establish and expand cooperation with local enforcement and research partners

- Develop close ties with local stakeholders and encourage their active involvement

- Actively represent Yarari interests in regional marine mammal policy development and research initiatives

\subsection{Research priorities}

- Use remote methods (AIS) and current port fishery sampling to monitor fishery activity, and ship traffic inside Yarari

- Use passive acoustic monitoring and sighting records to monitor cetacean distribution and abundance

- Use passive acoustic monitoring to measure and follow background noise levels

- Record and collect data on and specimens from stranding incidents using published guidelines and protocols

- Subsample stranding fatalities to determine contaminant loads of the cetaceans inside Yarari and their prey species

- Document the extent and source of marine debris contamination inside the sanctuary 


\section{Acknowledgments}

Various experts, scientists and managers were found willing to contribute with information, reviews of text portions and expert advice. We are particularly grateful to Tadzio Bervoets (Nature Foundation St. Maarten), Jens Odinga (Saba Conservation Foundation), Dr. Nathalie Ward (Stellwagen), Romain Renoux (AGOA), Dr. Sarah Manuel (Senior Marine Conservation Officer, Bermuda) and Dr. Ingvild Harkes (WWF - The Netherlands) for also making time to fill out our questionnaire. Additional generous input was provided by Paul Hoetjes in all sections of this report while Kai Wulf told us about the practical challenges to be expected for management implementation on Saba. Finally, we thank Dr. Erwin Winter for suggesting many valuable improvements in the course of his internal review of our report.

This work was carried out by Wageningen Marine Research at the request of and with funding from the Ministry of Economic Affairs for the purposes of the Policy Support Research Theme "Caribbean Netherlands", under project BO-11-0191.02-054 (\#4318100101). We very are grateful to the Ministry of Economic Affairs for commissioning us this study. 


\section{Quality Assurance}

Wageningen Marine Research utilises an ISO 9001:2008 certified quality management system (certificate number: 187378-2015-AQ-NLD-RvA). This certificate is valid until 15 September 2018. The organisation has been certified since 27 February 2001. The certification was issued by DNV Certification B.V. 


\section{References}

Agence des aires marines protégées. 2012. Projet Plan de gestion Etat initial. Document de travail. Version au 18052012.

Agence des aires marines protégées. 2014. Agoa: protecting marine mammals in the French West Indies.

Ainslie, M. A., De Jong, C. A. F., Dol, H.S., Blacquière, G. and Marasini, C. 2009. Assessment of natural and anthropogenic sound sources and acoustic propagation in the North Sea. The Hague: TNO. Report TNO-DV 2009 C085.

Andre, M. and Kamminga, C. 2000. Rhythmic dimension in the echolocation click trains of sperm whales: a possible function of identification and communication J ournal of Marine Biological Association of the United Kingdom, Vol. 80, pp. 163-169.

Anonymous 1995. The killing of dolphins in Venezuela and the government prosecution against environmentalists for denouncing it. $14 \mathrm{pp}$.

Arocha, F., Pazos, A., Larez, A., Marcano, J., and Gutierrez, X. 2013. Enhanced monitoring of large pelagic fishes caught by the Venezuela Artisanal Off-shore Fleet targeting tuna and tuna-like species in the Caribbean Sea and adjacent northwestern Atlantic waters: A preliminary Analysis. Collect. Vol. Sci. Pap. ICCAT, 69(3), 1317-1332.

Au, D., and Perryman, W. 1982. Movement and speed of dolphin schools responding to an approaching ship. Fish Bull (US) 80:371-379.

Au, W. W. L., Pack, A. A., Deakos, M. H. and Andrews, K. 2006. Acoustic properties of humpback whale songs. Acoustical Society of America 2006. DOI: 10.1121/1.2211547.

Barros, N.B. and Debrot, A.O. 2006. Status of small cetaceans in the Leeward Dutch Antilles.

Baulch, S. and Perry, C. 2014a. Evaluating impacts of marine debris ingestion and reporting interactions to the IWC. Paper SC65b/E02 presented to the IWC Scientific Committee, May 2014.

Baulch, S. and Perry, C. 2014b. Evaluating the impacts of marine debris on cetaceans. Mar. Poll. Bull. 80(1): 210-21. [Available at: http://dx.doi.org/10.1016/j.marpolbul.2013.12.050].

Beek, I.J.M. van, Debrot, A.O., Röckmann, C. and Jak, R.G. 2015. Structure and financing of nature management costs in Caribbean Netherlands. Report number C033/15. 76 pp.

Beek, I.J.M. van, 2016. Ecological values of the 12 miles zone of Bonaire. Imares report C026/16, 34 pp.

Bejder, L., Samuels, A., Whitehead H., and Gales, N. 2006. Interpreting short-term behavioural responses to disturbance within a longitudinal perspective. Anim Behav 72:1149-1158.

Bejder, L. and Samuels, A. 2006. 12 Evaluating the effects of nature-based tourism on cetaceans. Books Online 2006, 229-256.

Bree, P.J.H. van, and Kristensen, I. 1974. On the intriguing stranding of four Cuvier's beaked whales, Ziphius cavirostris G. Cuvier, 1823, on the lesser Antillean island of Bonaire. Bijdragen tot de Dierkunde 44:235-238.

Bree, P.J.H. van, Creutzberg, F. and Kristensen, I. 1973. On strandings of Cuvier's whale, Ziphius cavirostris G. Cuvier, 1823, on the lesser Antillean islands of St. Maarten and Curaçao. Lutra 15: 6-8.

Buurt, G. van, 2001. Visserijbeleidsplan eilandgebied Curaçao. Dienst Landbouw, Veeteelt en Visserij, $42 \mathrm{pp}$.

Caldwell, D. K. and Caldwell, M.C. 1975. Dolphin and small whale fisheries of the Caribbean and West Indies: occurrence, history, and catch statistics- with special reference to the Lesser Antillean I sland of St. Vincent. J. Fish. Res. Board Can.32:105-110.

Campbell, G.S., Bilgre, B.A. and Defran, R.H. 2002. Bottlenose dolphins (Tursiops truncatus) in Turneffe Atoll, Belize: Occurrence, site fidelity, group size, and abundance. Aquat. Mamm. 28: 170-180.

Casanovas, P., Lynch, H.J and Fagan, W.F. 2014. Using citizen science to estimate lichen diversity. Biological Conservation 171: 1-8.

Cassoff, R.M., Moore, K.M., McLellan, W.A., Barco, S.G., Rotstein, D.S. and Moore, M.J. 2011. Lethal entanglement in baleen whales. Diseases of Aquatic Organisms 96: 175-185. 
Christiansen, F., Lusseau, D., Stensland, E., and Berggren, P. 2010. Effects of tourist boats on the behaviour of Indo-Pacific bottlenose dolphins off the south coast of Zanzibar. Endang Species Res, Vol. 11: 91-99, 2010 doi: 10.3354/esr00265.

Clapham, P.J. 2000. The humpback whale. Seasonal feeding and breeding in a baleen whale, p.173196. In: J. MANN; R.C. Connor; P.L. Tyack \& H. Whitehead (Eds). Cetacean Societies: Field Studies of Dolphins and Whales. Chicago, The University of Chicago Press, 433p

Constantine, R. and Baker, C.S. 1997. Monitoring the commercial swim-with-dolphin operations in the Bay of I slands, New Zealand. Department of Conservation, Wellington.

Cortés, E. 2002. Catches and catch rates of pelagic sharks from the northwestern Atlantic, Gulf of Mexico, and Caribbean. ICCAT Coll. Vol. Sci. Pap, 54(4), 1164-1181.

Couperus, A.S., van Beek, I.J.M, Debrot, A.O., Fassler, S.M.M. and Gastauer, S. 2014. A review of the small pelagics fishery resources of the Dutch Caribbean and adjacent areas. IMARES Report C142/14, $67 \mathrm{pp}$.

Cox T. M., Ragen, T. J., Read, A. J., Vos, E., Baird, R. W., Balcomb, K., Barlow, J., et al. 2016. Understanding the impacts of anthropogenic sound on beaked whales. Journal of Cetacean Research and Management 7:177-187.

DCCG (Dutch Caribbean Coast Guard). 2016. Jaarverslag 2015. Kustwacht voor het Koninkrijk der Nederlanden in het Caribisch Gebied. 21 pp.

Debrot, A. O., van Buurt, G., Caballero, A. and Antczak, A.A. 2006. A historical review of records of the West Indian manatee and the American crocodile in the Dutch Antilles. Car. J. Sci. 42(2): 272280.

Debrot, A.O. 1998. New cetacean records for Curaçao, Netherlands Antilles. Caribbean Journal of Science 34(1-2): 168-170.

Debrot, A.O. 2000. A review of records of the extinct West Indian monk seal, Monachus tropicalis (Carnivora: Phocidae), for the Netherlands Antilles. Marine Mammal Science 16: 834-837.

Debrot, A.O. and Bugter, R. 2010. Climate change effects on the biodiversity of the BES islands: Assessment of the possible consequences for the marine and terrestrial ecosystems of the Dutch Antilles and the options for adaptation measures. Alterra-IMARES-report, Alterra Wageningen UR Wageningen, 2010, $34 \mathrm{pp}$.

Debrot, A.O., Bron, P.S., de León, R. and Meesters, H.W.G. 2013b. Marine debris in mangroves and on the seabed: largely-neglected litter problems. Marine Pollution Bulletin 72: 1.

Debrot, A.O., Bradshaw, J.E. and Tiel, A.B. 1995. Tar contamination on beaches in Curaçao. Mar. Poll. Bull. 30: 689-693

Debrot, A.O., de Meyer, J.A. and Dezentjé, P.J.E. 1998. An overview of the cetacean fauna of the Leeward Dutch Antilles. Caribbean J ournal of Science 34: 204-210.

Debrot, A.O., Esteban, N., Bervoets, T., Hoetjes, P.C. and Scheidat, M. 2013a. Marine Mammals of the Northeastern Caribbean Windward Dutch Islands: Saba, St. Eustatius, St. Maarten, and the Saba Bank. Caribbean J ournal of Science, Vol. 47, No. 2-3, 159-172.

Debrot, A. O., de Graaf, M., Henkens, R., Meesters, H.G.W. and Slijkerman, D.M.E. 2011. A status report of nature policy development and implementation in the Dutch Caribbean over the last 10 years and recommendations towards the nature Policy Plan 2012-2017. I MARES Report C065/11. $41 \mathrm{pp}$.

Debrot, A.O., Tiel, A.B. and Bradshaw, J.E. 1999. A study of beach debris contamination in Curaçao, Netherlands Antilles. Mar. Poll. Bull. 38: 795-801.

Debrot, A.O., van Buurt, G., Caballero, A. and Antczak, A.A. 2006. A historical review of records of the West Indian manatee and the American crocodile in the Dutch Antilles. Caribbean Journal of Science 42(2): 272-280.

Debrot, A.O., van Rijn, J., Bron, P.S. and de Leon, R. 2013c. A baseline assessment of beach debris and tar contamination in Bonaire, Southeastern Caribbean. Marine Pollution Bulletin 72: 325-329.

Debrot, A.O., Vinke, E., van der Wende, G., Hylkema, A. and Reed, J.K. 2014. Deep-water marine litter densities and composition from submersible video-transects around the ABC-islands, Dutch Caribbean. Marine Pollution Bulletin, online.

Debrot, A.O., Witte, R.H. and Scheidat, M. 2011b. The marine mammals of the Dutch Caribbean: a comparison between EEZ sectors, contrasts and concerns. http://library. wur.nl/WebQuery/wurpubs/410462 
Debrot, A.O., Witte, R.H., Scheidat, M. and Lucke, K. 2011a. A Proposal Towards a Dutch Caribbean Marine Mammal Sanctuary. Wageningen I MARES Report number C149/11.

http://edepot. wur.nl/189433

Deutsch, C.J., Self-Sullivan, C. and Mignucci-Giannoni, A. 2008. Trichechus manatus. The IUCN Red List of Threatened Species 2008: e.T22103A9356917. http://dx.doi.org/10.2305/IUCN.UK.2008.RLTS.T22103A9356917.en. Downloaded on 07 June 2016.

Dilrosun, F., 2000. Monitoring the Saba Bank fishery. Department of Public Health and Environmental Hygiene, Environmental Division. Curaçao, Netherlands Antilles, 56 pp.

Dilrosun, F., 2007. Eindevaluatie Visserijbeleid, 2001. Dienst Landbouw, Veeteelt en Visserij.

ECLAC (Economic Commission for Latin America and the Caribbean), 1998. National implementation of the SIDS/POA. A Caribbean perspective. ECLAC, Trinidad.

Escalle, L., Capietto, A., Chavance, P., Dubroca, L., De Molina, A. D., Murua, H., Gaertner, D., Romanov, E., Spitz, J., Kiszka J. J., Floch L., Damiano A. and Merigot B. 2015. Cetaceans and tuna purse seine fisheries in the Atlantic and Indian Oceans: interactions but few mortalities. Marine Ecology Progress Series, 522, 255-268.

Evans, D. L. and England, G. R. 2001. Joint interim report, Bahamas Marine Mammal Stranding Event of 15-16 March 2000. Washington, DC: U.S. Department of Commerce and Secretary of the Navy.

Fair, P.A., Adams, J., Mitchum, G., Hulsey, T.C., Reif J.S., Houde, M., Muir, D., Wirth, E., Wetzel, D., Zolman, E., McFee, W. and Bossart, G.D.. 2010. Contaminant blubber burdens in Atlantic bottlenose dolphins (Tursiops truncatus) from two southeastern US estuarine areas: Concentrations and patterns of PCBs, pesticides, PBDEs, PFCs, and PAHs, Sci Total Environ 408(7), pp 1577-1597, http://dx.doi.org/10.1016/j.scitotenv.2009.12.021.

FAO. 2016. FAO yearbook. Fishery and Aquaculture Statistics. 2014.

Fernández, A. Edwards, J. F., Rodríguea, F., Espinosa de los Monteros, A., Herráez, P., Castro, P. et al. 2005. "Gas and fat embolic syndrome" involving a mass stranding of Beaked Whales (family Ziphiidae) exposed to anthropogenic sonar signals. Veterinary Pathology. 42, 446-457.

Fossi, M., Giannetti, M., Guerranti, C., Marsili, L., Coppola, D., Panti, C. and Minutoli, R. 2012. Are baleen whales exposed to the threat of microplastics? A case study of the Mediterranean fin whale (Balaenoptera physalus). Marine Pollution Bulletin 64(11), 2374-9.

Gaertner, D. and Medina-Gaertner, M. 1999. An overview of the tuna fishery in the southern Caribbean Sea. In: Scott MD, Bayliff WH, Lennert-Cody CE, Schaefer KM (eds) Proceedings of the International Workshop on Fishing for Tunas Associated with Floating Objects, La Jolla, CA, 11-13 Feb 1992. Inter-Am Trop Tuna Comm Spec Rep 11: 66-86

Gaskin, D.E., Smith, G.J.D., Arnold, P.W. and Louisy, M.V. 1974. Mercury, DDT, dieldrin and PCB in two species of odontoceti from St. Lucia, Lesser Antilles. J. Fish. Res. Bd. of Can. 31. 1235-1239.

Gebco. 2014. The GEBCO_2014 Grid, www.gebco.net (accessed J une 2016)

Geelhoed, S.C.V. and Verdaat, J.P. 2012. Cruise report seabird and cetacean survey Saba bank expedition October 2011. IMARES report C062/12.

http://www.dcbd.nl/sites/www.dcbd.nl/files/documents/C062.12.CruisereportBirdsMammals.SG_.j $d_{-} . p d f$

Geelhoed, S.C.V., Janinhoff, N., Verdaat, J.P., van Bemmelen, R.S.A. and Scheidat, M. 2014. Aerial surveys of marine mammals and other fauna around Aruba, Curaçao and Bonaire, November 2013. IMARES report C012/14. 22 pp.

Government of Bermuda. 2013a. Bermuda's exclusive economic zone and its future. September 2013. A consultation document. Government of Bermuda, Ministry of Environment and Planning, Sustainable Development Department. Downloaded on 21 July 2016 at: http://www.sdbermuda.bm/Uploaded\%20Files/130917\%204644_SD\%20Book\%20Final\%20_Web. pdf.pdf

Government of Bermuda. 2013b. The future of Bermuda's Exclusive Economic Zone. Outcome of the public consultation, September 3 to October 31, 2013. Government of Bermuda, Ministry of Environment and Planning, Sustainable Development Department. Downloaded on 21 July 2016 at: http://www.sdbermuda.bm/Uploaded\%20Files/141105\%20SDD\% 20EEZ\% 20$\%$ 20Report\%200n\%20Consultation.pdf.pdf

Government of Bermuda. 2014. Bermuda marine enhancement structure policy. Position statement and evaluation guidelines. 18th February 2014. Government of Bermuda, Ministry of public works, Department of conservation services. Downloaded on 21 July 2016 at: 
https://static1.squarespace.com/static/501134e9c4aa430673203999/t/55b26dfee4b07f66d96077

ac/1437756926576/Bermuda+Marine+Enhancement+Structure+Policy+2014. pdf

Government of Bermuda. 2015. PATI Information Statement. Government of Bermuda ministry of the health, seniors and environment. Downloaded on 21 July 2016 at:

http://static1.squarespace.com/static/501134e9c4aa430673203999/t/558d50d4e4b0fd0c637c4fa

3/1435324628937/Department+of+Conservation+Services+- +I nformation+Statement+-

+March+2015.pdf

Government of Bermuda. 2016. Budget Statement In support of the Estimates of Revenue and Expenditure 2016-2017. Presented by The Hon. E.T. Richards, JP, MP Minister of Finance, 19 February 2016. Downloaded on 21 July 2016 at:

http://www.caribbeanelections.com/eDocs/budget/bm_budget/bm_budget_2016.pdf

de Graaf, M., Brunel, T., Nagelkerke, L. Debrot, A.O. 2017. Status and trends Saba Bank fisheries: 2015.; Wageningen, Wageningen Marine Research (University \& Research centre), Wageningen Marine Research report C077/17. 124 pp.

Grant, S. and Berkes, F. 2007. Fisher knowledge as expert system: A case from the longline fishery of Grenada, the Eastern Caribbean. Fisheries Research, 84(2), 162-170.

Grigg, E. and Markowitz, H. 1997. Habitat use by bottlenose dolphins (Tursiops truncatus) at Turneffe Atoll, Belize. Aquat. Mamm. 23: 163-170

Halpern, B.S., Walbridge, S., Selkoe, K.A., Kappel, C.V., Micheli, F., D'Agrosa, C., Bruno, J.F., Casey, K.S., Ebert, C., Fox, H.E., Fujita, R., Heinemann, D., Lenihan, H.S., Madin, E.M.P., Perry, M.T., Selig, E.R., Spalding, M., Steneck, R., and Watson, R. 2008. A global map of human impact on marine ecosystems. Science, 319 (5865), pp. 948-952.

Halpern, B. S., Frazier, M., Potapenko, J., Casey, K. S., Koenig, K., Longo, C., Stewart Lowndes, J., Cotton Rockwood, R., Selig E.R., Selkoe, K.A. and Walbridge, S. 2015a. Spatial and temporal changes in cumulative human impacts on the world's ocean. Nature Communications, 6(May), 7615. http://doi.org/10.1038/ncomms8615

Halpern, B., Frazier, M., Potapenko, J., Casey, K., Koenig, K., Longo, C., Lowndes, J., Rockwood, C., Selig, E., Selkoe, K., and Walbridge, S. 2015b. Cumulative human impacts: raw stressor data (2008 and 2013). KNB Data Repository. doi: 10.5063/F1S180FS (accessed J uly 2016)

Hamer, D.J., Childerhouse, S.J., McKinlay, J.P., Double, M.C., and Gales, N.J. 2015. Two devices for mitigating odontocete bycatch and depredation at the hook in tropical pelagic longline fisheries. ICES J ournal of Marine Science: Journal du Conseil, fsv013.

Hernandez-Milian, G., Goetz, S., Varela-Dopico, C., Rodriguez-Gutierrez, J., Romón-Olea, J., FuertesGamundi, J. R., Ulloa-Alonso, E., Tregenza, N.J.C., Smerdon, A., Otero, M.G., Tato, V., Wang, J., Santos, M.B., López, A., Lago, R., Portela, J.M. and Pierce, G.J. 2008. Results of a short study of interactions of cetaceans and longline fisheries in Atlantic waters: environmental correlates of catches and depredation events. Hydrobiologia, 612(1), 251-268.

Hoop, J.M. van der, Moore, M.J., Barco, S.G., Cole, T.V.N., Daoust, P.-Y., Henry, A.G., MCAlpine, D.F., McLellan, W.A., Wimmer, T. and Solow, A.R. 2013. Assessment of Management to Mitigate Anthropogenic Effects on Large Whales. Conservation Biology, 27: 121-133. doi: 10.1111/j.15231739.2012.01934.xref

Hoyt, E. and Hvenegaard, G.T. 2002. A Review of Whale-Watching and Whaling with Applications for the Caribbean. Coastal Management, 30:381-399.

IFG (It Fryske Gea) 2014a. Jaarverslag 2013. It Fryske Gea, Van Harinxmaweg 17, 9246 TL Olterterp, The Netherlands. 20 pp.

IFG (It Fryske Gea) 2014b. Jaarrekening Boekjaar 2013. It Fryske Gea, Van Harinxmaweg 17, 9246 TL Olterterp, The Netherlands. 53 pp.

IWC. 2010. Report of the workshop on cetaceans and climate change. J. Cetacean res. Manage. 11 (suppl 2): 451-480.

IWC. 2014. Report of the J oint IWC-SPAW Workshop to Address Collisions Between Marine Mammals and Ships with a Focus on the Wider Caribbean. Available at http://www.car-spawrac.org/I MG/pdf/Ship_Strikes_Report_FINAL-July25.pdf

IWC-SPAW. 2014. Report of the Joint IWC-SPAW Workshop to Address Collisions Between Marine Mammals and Ships with a Focus on the Wider Caribbean. Downloaded on $7 \mathrm{~J}$ uly 2016 at: http: //www.car-spaw-rac.org/IMG/pdf/Ship_Strikes_Report_FINAL-July25.pdf

Janik, V.M., and Thompson, P.M. 1996. Changes in surfacing patterns of bottlenose dolphins in response to boat traffic. Mar Mamm Sci 12:597-602. 
Jepson, P.D., Deaville, R., Barber, J.L., Aguilar, À., Borrell, A., Murphy, S., Barry, J., Brownlow, A., Barnett, J., Berrow, S., Cunningham, A.A., Davison, N.J., Ten Doeschate, M., Esteban, R., Ferreira, M., Foote, A.D., Genov, T., Giménez, J., Loveridge, J., Llavona, Á., Martin, V., Maxwell, D.L., Papachlimitzou, A., Penrose, R., Perkins, M.W., Smith, B., De Stephanis, R., Tregenza, N., Verborgh, P., Fernandez, A., and Law, R.J. 2016. PCB pollution continues to impact populations of orcas and other dolphins in European waters. Scientific Reports 6: 18573. doi: 10.1038/srep18573.

Kaschner, K., Kesner-Reyes, K., Garilao, C., Rius-Barile, J., Rees, T. and R. Froese. 2015. AquaMaps: Predicted range maps for aquatic species. World wide web electronic publication, www.aquamaps.org, Version 08/2015 (accessed Aug. 2016)

Katona, S.K. and Beard, J.A. 1990. Population size, migrations and feeding aggregations of the humpback whale (Megaptera novaeangliae) in the Western North Atlantic Ocean. SC/A88/ID2. Page 295-305. In: Individual Recognistion of Cetaceans: Use of photo-identification and other techniques to estimate population parameters. In: Hammond, P., Mizroch, S.A., Donovan, G.P. (Eds). Report of the International Whaling Commission. Special Issue 12. Cambridge 1990.

Kenney, R.D., Mayo, C.A. and Winn, H.E. 2001. Migration and foraging strategies at varying special scales in western North Atlantic right whales. Journal of Cetacean Research and Management, Special I ssue 2, 251-260.

Kerr, K.A., Defran, R.H. and Campbell, G.S. 2005. Bottlenose Dolphins (Tursiops truncatus) in the Drowned Cayes, Belize: Group Size, Site Fidelity and Abundance. Caribbean J ournal of Science, 41 (1). pp. 172-177.

Kerstetter, D.W. and Graves, J.E. 2006. Effects of circle versus J-style hooks on target and non-target species in a pelagic longline fishery. Fisheries Research, 80(2), 239-250.

Klok, C., Debrot, A.O., Meesters, H.W.G., Stapel, J. and Slijkerman, D.M.E. 2011. Second opinion NuStar terminal expansion Report number C148/11 [confidential]. $30 \mathrm{pp.}$

Knowlton, A.R., Hamilton, P.K., Marx, M.K., Pettis, H.M. and Kraus, S.D. 2012. Monitoring North Atlantic right whale (Eubalaena glacialis) entanglement rates: a $30 \mathrm{yr}$. retrospective. Marine Ecology Progress Series 466: 293

Laffoley, D.d'A., Roe, H.S.J., Angel, M.V., Ardron, J., Bates, N.R., Boyd, I.L., Brooke, S., Buck, K.N., Carlson, C.A., Causey, B., Conte, M.H., Christiansen, S., Cleary, J., Donnelly, J., Earle, S.A., Edwards, R., Gjerde, K.M., Giovannoni, S.J., Gulick, S., Gollock, M., Hallett, J., Halpin, P., Hanel, R., Hemphill, A., Johnson, R.J., Knap, A.H., Lomas, M.W., McKenna, S.A., Miller, M.J., Miller, P.I., Ming, F.W., Moffitt, R., Nelson, N.B., Parson, L., Peters, A.J., Pitt, J., Rouja, P., Roberts, J ., Roberts, J., Seigel, D.A., Siuda, A.N.S., Steinberg, D.K., Stevenson, A., Sumaila, V.R., Swartz, W., Thorrold, S., Trott, T.M., and Vats, V. 2011. The protection and management of the Sargasso Sea: The golden floating rainforest of the Atlantic Ocean. Summary Science and Supporting Evidence Case. Sargasso Sea Alliance, 44 pp. Downloaded on 21 July 2016 at: http://www.sargassoseacommission. org/storage/documents/Sargasso. Report. 9.12.pdf

Lancho Diéguez. 2012. Demonstration project: marine mammal sanctuary management plan in the Dominican republic. Working document UNEP LifeWeb Inter-regional Workshop on Broad-scale Marine Spatial Planning and Transboundary Marine Mammal Management, 21-24 May 2012, Panama City. Patricia Lancho Diéguez, Executive Director, FUNDEMAR, Dominican Republic

Lindop, A., Bultel, E., Zylich, K. and Zeller, D. 2015. Reconstructing the former Netherlands Antilles marine catches from 1950 to 2010. Fisheries Centre The University of British Columbia Working Paper Series

Luksenburg, J.A. 2013. The cetaceans of Aruba, southern Caribbean. J. Mar. Biol. Assoc. UK: In press. doi: 10.1017/S0025315413000337.

Luksenburg, J.A. 2014. Prevalence of External Injuries in Small Cetaceans in Aruban Waters, Southern Caribbean. PLoS ONE 9(2): e88988. doi: 10.1371/ journal.pone.0088988.

Lusseau, D. 2003. Effects of tour boats on the behavior of bottlenose dolphins: using Markov chains to model anthropogenic impacts. Conserv Biol 17:1785-1793.

Mandelman, J.W., Cooper, P.W., Werner, T.B., and Lagueux, K.M. 2008. Shark bycatch and depredation in the US Atlantic pelagic longline fishery. Reviews in Fish Biology and Fisheries, 18(4), 427-442.

Mann D., Hill-Cook, M., Manire, C., Greenhow, D., Montie, E., Powell, J., Wells, R., Bauer, G., Cunningham-Smith, P., Lingenfelser, R., DiGiovanni Jr., R., Stone, A., Brodsky, M., Stevens, R., Kieffer, G., and Hoetjes, P. 2010. Hearing Loss in Stranded Odontocete Dolphins and Whales. PLoS ONE 5(11): e13824. oi: 10.1371/journal. pone.0013824 
Marine Copernicus. 2016. Global Biogeochemical Reanalysis Product GLOBAL_REANALYSIS_BIO_001_018, a.o. Primary Productivity, http://marine.copernicus.eu/ (accessed Aug. 2016)

Meesters E., Slijkerman, D., de Graaf, M. and Debrot, D. 2010. Management plan for the natural resources of the EEZ of the Dutch Caribbean. Wageningen IMARES Report number C100/10.

Mignucci-Giannoni, A.A. 1998. Zoogeography of cetaceans off Puerto Rico and the Virgin Islands. Carib. J. Sci. 34(3-4): 173-190.

Mohammed, E., Straker, L.E. and Jardine, C. 2003. St. Vincent and the Grenadines: Reconstructed fisheries catches and fishing effort, 1942-2001. Fisheries Centre Research Reports 11(6): 95-116.

Murphy, S., Barber, J.L., Learmonth, J.A., Read, F.L., Deaville, R., Perkins, M.W., Brownlow, A., Davison, N., Penrose, R., Pierce, G.J., Law, R.J. and Jepson, P.D. 2015. Reproductive Failure in UK Harbour Porpoises Phocoena phocoena: Legacy of Pollutant Exposure? PLoS ONE 10(7): e0131085. doi: 10.1371/journal. pone. 0131085

Myers R.A. and Worm B. 2003. Rapid worldwide depletion of predatory fish communities. Nature 2003; 423: 280-283.

Nagelkerken, I. and Debrot, A.O. 1995. Mollusc communities of tropical rubble shores of Curaçao: long-term (7+ years) impacts of oil pollution. Mar. Poll. Bull. 30: 592-598.

Nagelkerken, I., Wiltjer, M., Debrot, A.O. and Pors, L.P.J.J. 2001. Baseline study of submerged marine debris at beaches in Curaçao, West Indies. Mar. Poll. Bull. 42: 786-789.

National Marine Sanctuary Program. 2006. Gerry E. Studds Stellwagen Bank National Marine Sanctuary Condition report 2006. U.S. Department of Commerce, National Oceanic and Atmospheric Administration, National Marine Sanctuary Program, Silver Spring, MD. 39pp. Downloaded on 20 July 2016 at: http://sanctuaries.noaa.gov/science/condition/pdfs/sb_condition_hr.pdf

National Ocean Service. (n.d.). Stellwagen Bank National Marine Sanctuary Web Group. Accessed 15 July 2016 at: http://stellwagen.noaa.gov/sister/welcome.html

Nature Foundation St Maarten. 2011. Results of Nature Foundation Marine Mammal Monitoring Project Jan-May 2011.

NMFS. 2011. Bottlenose dolphin (Tursiops truncatus truncatus): Puerto Rico and U.S. Virgin Islands Stock Marine Mammal Stock Assessment Reports. Available at: http://www.nmfs.noaa.gov/pr/pdfs/sars/ao2011dobn-prusvi. pdf

NOAA. 2005. Our national marine sanctuaries Strategic Plan 2005 - 2015, U.S. Department of Commerce, National Oceanic and Atmospheric Administration, National Ocean Service, National Marine Sanctuary Program. Available at: http://sanctuaries.noaa.gov/management/pdfs/nms_strategic_plan_2005.pdf

NOAA. 2010. Stellwagen Bank National Marine Sanctuary Final Management Plan and Environmental Assessment. U.S. Department of Commerce. National Oceanic and Atmospheric Administration. Office of National Marine Sanctuaries. Silver Spring, MD.

NOAA and the Government of Bermuda. 2012. Memorandum of understanding between the US of America and the Government of Bermuda to collaborate on international protection, conservation and management of the humpback whale. NOS Agreement code: MOA 2012-058/8588. Accessed on 15 July 2016 at: http://stellwagen.noaa.gov/sister/pdfs/bermuda_moa12.pdf

Nøttestad, L., Krafft, B.A., Anthonypillai, V., Bernasconi, M., Langård, L., Mørk, H.L. and Fernö, A. 2015. Recent changes in distribution and relative abundance of cetaceans in the Norwegian Sea and their relationship with potential prey. Front. Ecol. Evol. 2:83. doi: 10.3389/fevo.2014.00083

Nowacek, S.M., Wells, R.S., and Solow, A.R. 2001. Short-term effects of boat traffic on bottlenose dolphins, Tursiops truncatus, in Sarasota Bay, Florida. Mar Mamm Sci 17:673-688.

NPS (National Park Service) 2008. BUDGET JUSTIFICATIONS and Performance Information: Fiscal Year 2008. The United States Department of the Interior. $549 \mathrm{pp}$.

NPS (National Park Service) 2009. Strategic plan for natural resource inventories: FY 2008 - FY 2012. Natural Resource Report NPS/NRPC/NRR-2009/094. National Park Service, Fort Collins, Colorado.

Pace, R., Cole, T. and Henry, A. 2014. Incremental Fishing Gear Modifications Fail to Significantly Reduce Large Whale Serious Injury Rates. Endangered Species Research. 26: 115-126.

Parijs, S. M. van, and Corkeron, P. 2001. Boat traffic affects the acoustic behaviour of Pacific humpback dolphins, Sousa chinensis. J Mar Biol Assoc UK 81:533-538. 
Parsons, E.C.M., Bonnelly de Calventi, I., Whaley, A., Rose, N.A. and Sherwin, S. 2010. A note on illegal captures of wild bottlenose dolphins (Tursiops truncatus) from the coastal waters of the Dominican Republic. J. Int. Wildl. Law Policy 13(3): 240-244.

Payne, P.M., Wiley, D.N., Young, S.B., Pittman, S., Clapham, P.J . and J ossi. J.W.1990. Recent fluctuations in the abundance of baleen whales in the southern Gulf of Maine in relation to changes in selective prey. Fishery Bulletin. 88, 687-696.

Poussart, J-N. 2012. Marine Mammal Protection and Species Richness in the Wider Caribbean Region. UNEP/GRID-Arendal, Mar. 2012. Downloaded on 14 June 2016 at: http://www.car-spawrac.org/IMG/pdf/Car_MPAs_Species_Richness_v1.pdf

Reeves, R.R., McClellan, K., and Werner, T.B. 2013. Marine mammal bycatch in gillnet and other entangling net fisheries, 1990 to 2011. Endangered Species Research, 20: 71-97.

República Dominicana. 2015. Plan de Manejo del Santuario de Mamíferos Marinos de los Bancos de La Plata y La Navidad. Downloaded on 21 J uly 2016 at: http://cep.unep.org/cepdocuments/plan_manejo-web.pdf

Reyer, C.P.O., Adams, S., Albrecht, T., Baarsch, F., Boit, A., Canales Trujillo, N., Cartsburg, M., Coumou, D., Eden, A., Fernandes, E., Langerwisch, F., Marcus, R., Mengel, M., Mira-Salama, D., Perette, M., Pereznieto, P., Rammig, A., Reinhardt, J., Robinson, A., Rocha, M., Sakschewski, B., Schaeffer, M., Schleussner, C.-F., Serdeczny, O. and Thonicke, K. 2015. Climate change impacts in Latin America and the Caribbean and their implications for development. Reg Environ Change DOI 10.1007/s10113-015-0854-6

Richard, G. 2001. Figures anthropomorhes et zoomorphes de Guadeloupe: une donnee nouvelle. Proc. Internat. Congr. Caribb. Archaeol. 19(2): 290-299.

Richardson, W. J., Greene, C. R., Malme, C. I. and Thomson, D. H. 1995. Marine mammals and noise. Academic Press, Inc., San Diego, CA. ISBN 0-12-588441-9.

Ridoux, V., Certain, G., Doremus, G., Laran, S., van Canneyt, O. and Watremez, P. 2010. Mapping diversity and relative density of cetaceans and other pelagic megafauna across the tropics: general design and progress of the REMMOA aerial surveys conducted in the French EEZ and adjacent waters. SC/62/E14. Paper presented to the IWC Scientific Committee.

Rinaldi, C. and Rinaldi, R. 2014. A deadly mother-calf bond in Caribbean sperm whales. national Whaling Commission 2014 SC/65b/HIM02.

Risch, D. and de Haan, D. 2016. Humpback and minke whale acoustic presence with reference to fish sounds and ambient noise levels at Saba Bank, Caribbean Windward Dutch Islands. Imares report C067/16, $22 \mathrm{pp}$

Risch, D., Castellote, M., Clark, C.W., Davis, G.E., Dugan, P.J., Hodge, L.E.W., Kumar, A., Lucke, K., Mellinger, D.K., Nieukirk, S.L., Popescu, M., Ramp, C., Read, A.J., Rice, A.N., Silva, M.A., Siebert, U., Stafford, K. and van Parijs, S.M. 2014. Seasonal migrations of North Atlantic minke whales: novel insights from large-scale passive acoustic monitoring networks. Movement Ecology 2:24. doi: 10.1186/s40462-014-0024-3

Risch, D., Clark, C. W., Dugan, P. J., Popescu, M., Siebert, U., and Van Parijs, S.M. 2013. Minke whale acoustic behavior and multi-year seasonal and diel vocalization patterns in Massachusetts Bay, USA. Mar Ecol Prog Ser 489: 279-295.

Robbins, J., Barlow, J., Burdin, A.M., Calambokidis, J., Gabriele, C., Clapham, P., Ford, J., LeDuc, R., Mattila, D.K., Quinn, T., Rojas-Bracho, L., Straley, J., Urban, J., Wade, P., Weller, D., Witteveen, B.H., Wynne, K. and Yamaguchi, M. 2007. Comparison of humpback whale entanglement across the North Pacific Ocean based on scar evidence. Unpublished report to the Scientific Committee of the International Whaling Commission. Report number SC/59/BC

Rogers, C.A., Brunnick, B.J., Herzing, D.L. and Baldwin, J.D. 2004. The social structure of bottlenose dolphins, Tursiops truncatus, in the Bahamas. Mar. Mamm. Sci. 20:688-708.

Romero, A. and West, S.E. (eds) 2005. Environmental issues in Latin America and the Caribbean. Springer, Dordrecht.

Ruzicka, J.J., Steele, J.H., Ballerini, T., Gaichas, S.K., and Ainley, D.G. 2013. Dividing up the pie: Whales, fish, and humans as competitors. Progress in Oceanography, 116, 207-219.

Saez, L., Lawson, D., DeAngelis, M., Petras, E., Wilkin, S., and Fahy, C. 2013. Understanding the cooccurrence of large whales and commercial fixed gear fisheries off the west coast of the United States. NOAA Technical Memorandum NMFS: NOAA-TM-NMFS-SWR-044.

Salata, G.G., Wade, T.L., Sericano, J.L. Davis, J.W. and Brooks, J.M. 1995. Analysis of Gulf of Mexico bottlenose dolphins for organochlorine pesticides and PCBs. Environ. Poll. 88: 167-175. 
Scheidat, M.S., Boman, E., Devaasuren, N. Geelhoed, S. and de Graaf, M. 2015. Monitoring cetacean occurrence in coastal waters of the Caribbean Netherlands (Saba, St. Eustatius \& Bonaire) using port sampling. I MARES Report C038/15.

Slijkerman, D., van Maren, B., Debrot, A.O., Stapel, J., Meesters, E., Davaasuren, N. and van Dalfsen, J. 2011. Quick-scan environmental impact assessment of the St. Eustatius harbor extension. Deltares Report 1205206-000, IMARES report C085/11. 42 pp.

Southall, B.L., Bowles, A.E., Ellison, W.T., Finneran, J.J., Gentry, R.L, Greene J r., Ch., Kastak, D., Ketten, D.R., Miller, J.H., Nachtigall, P.E., Richardson, W.J., Thomas, J.A., and Tyack, P.L. 2007. Marine Mammal Noise Exposure Criteria. Aquatic Mammals 33, 410-521.

SPAW-RAC. 2012. SPAW-RAC Mapping Application. Project "Broad-scale marine spatial planning of mammal corridors \& protected areas in Wider Caribbean \& Southeast \& Northeast Pacific" (20102012). Accessed on 30 June 2016 at: http://www.car-spaw-rac.org/?-SPAW-RAC-MappingApplication-

Stanistreet, J.E., Risch, D., and Van Parijs, S.M. 2013. Passive Acoustic Tracking of Singing Humpback Whales (Megaptera novaeangliae) on a Northwest Atlantic Feeding Ground. PLoS ONE 8(4): e61263. doi: 10.1371/journal.pone. 0061263

Stensland, E., and Berggren, P. 2007. Behavioural changes in female Indo-Pacific bottlenose dolphins in response to boat-based tourism. Mar Ecol Prog Ser 332:225-234.

Stevick, P.T., Bouveret, L., Gandilhon, N., Rinaldi, C., Rinaldi, R., Broms, F., Carlson, C., Kennedy, A., Ward, N., and Wenzel, F. 2014. Humpback whales in the southeast Caribbean are behaviourally distinct from those off the Dominican Republic. J ournal of Cetacean Research and Management

Sturm, M.G. de L. 1991. The living resources of the Caribbean Sea and adjacent areas. Car. Mar. Stud. (1\&2): 18-44.

Sybesma, J., van't Hof, T., and Pors L.P.J.J . 1993. Marine survey area: an inventory of the natural and cultural marine resources of St. Eustatius, Netherlands Antilles

Taylor, B.L., Baird, R., Barlow, J., Dawson, S.M., Ford, J., Mead, J.G., Notarbartolo di Sciara, G., Wade, P. and Pitman, R.L. 2011. Globicephala macrorhynchus. The IUCN Red List of Threatened Species 2011: e.T9249A12972356. http://dx.doi.org/10.2305/IUCN.UK.20112.RLTS.T9249A12972356.en. Downloaded on 07 J une 2016.

UNEP. 2008. Action plan for the conservation of marine mammals (MMAP) in the Wider Caribbean Region. United Nations Environment Programme, 10 November 2008. Downloaded on 14 June 2016 at: http://www.car-spaw-rac.org/IMG/pdf/Action_Plan_for_MM_conservation_in_WCR-2.pdf

UNEP. 2011. Report of the Regional Workshop on Marine Mammal Watching in the Wider Caribbean Region. Panama City, Panama, 19-22 October 2011. Downloaded on 30 June 2016 at: http: //www.car-spaw-

rac.org/IMG/pdf/report_of_the_regional_workshop_on_marine_mammal_watching_in_the_wider_ caribbean_region_-_en.pdf

UNEP. 2012. Report on the implementation of activities in support of the action plan for the conservation of marine mammals (MMAP). UNEP(DEPI)/CAR WG.34/I NF.6, 12 October 2012.

UNEP. 2014. Ecological networks: case studies, challenges and lessons learned. United Nations Environment Programme - Convention on Migratory Species. UNEP/CMS/ScC18/Inf.10.3.1, 30 May 2014. Accessed on 15 July 2016 at:

http://www.cms.int/sites/default/files/document/Inf_10_3_1_Case_Studies_Ecological_Networks. pdf

UNEP (United Nations Environment Programme). 2008. Marine litter in the Wider Caribbean: a regional overview and action plan. Car. Envir. Progr./CRCU. Kingston, Jamaica. pp. 81.

UNEP. 2007. UNEP-CEP Training of Trainers in Marine Protected Areas Management. Downloaded on 21 July 2016 at: http://www.cep.unep.org/publications-and-resources/promotionalmaterial/publications/spaw/tot-manualenglish.pdf/@@download/file/TOT\%20Manual\%20English.pdf

UNEP. 2012. Proposed areas for inclusion in the SPAW list. Annotated format for presentation report for: Sanctuaire Agoa, France.

UNEP-CEP. 2011a. A Summary of Whale Watching Regulations, Codes, Guidelines And Decrees In The Wider Caribbean Region. Prepared for the UNEP Regional Workshop on Marine Mammal Watching in the Wider Caribbean Region in Panama City, Panama, 19 - 22 October 2011.

UNEP-CEP. 2011b. The Development of Overarching Principles and Best Practice Guidelines for Marine Mammal Watching in the Wider Caribbean Region (WCR). Prepared for the UNEP Regional 
Workshop on Marine Mammal Watching in the Wider Caribbean Region in Panama City, Panama, 19 - 22 October 2011.

UNEP-CEP. 2011c. United Nations Environmental Programme, Report of the Regional Workshop on Marine Mammal Watching in the Wider Caribbean Region. 2011. Available at http://www.cep.unep.org/meetings-events/regional-workshop-on-marine-mammal-watching-inthe-wider-caribbeanregion/Report\% 20of\% 20the\% 20Regional\% 20Workshop\% 20on\% 20Marine\% 20Mammal\% 20Watchi ng\%20in\% 20the\% 20Wider\% 20Caribbean\% 20Region\% 20-\% 20FR.pdf/view

Vail, C. 2005. Socio-economic assessment of marine mammal utilization in the Wider Caribbean region: Captivity, viewing and hunting. Information paper presented at the United Nations Environment Programme Regional Workshop of Experts on the Development of the Marine Mammal Action Plan for the Wider Caribbean Region, Barbados, 18-21 July 2005. UNEP(DEC)/CAR WG.27/INF 6. Available at: http://cep.unep.org/content/wg31-inf1en. pdf-1.

Visserijbesluit BES, 10-10-2010. Available at (in Dutch): http://wetten. overheid.nl/BWBR0028413/2010-10-10/0/Artikel7/informatie

Visserijwet BES, 25-01-2014. Available at (in Dutch): http://wetten.overheid.nl/BWBR0028168/201401-25/0/HoofdstukIV/Artikel14/informatie\#Algemeen

Waerebeek, K. van, Sequeira, M., Williamson, C., Sanino, G.P., Gallego, P. and Carmo, P. 2006. Livecaptures of common bottlenose dolphins Tursiops truncatus and unassessed bycatch in Cuban waters: Evidence of sustainability found wanting. Lat. Am. J. Aquat. Mamm. 5(1): 39-48.

Watkins, W.A., Moore, K.E., and Tyack, P. 1985. Sperm whale acoustic behaviours in the southeast Caribbean. Cetology 49: 1-15.

Weidner, D.M., Laya, G.E. and Serano, J.A. 2001. World swordfish fisheries: an analysis of swordfish fisheries, market trends and trade patterns, past-present-future. Vol. IV. Latin America, Part B. Caribbean, Section, 4, 1053-1145.

Weilgart, L.S. 2007. A brief review of known effects of noise on marine mammals. International Journal of Comparative Psychology, 2007, 20, 159-168.

Weinrich, M., Martin, M., Griffiths, R., Bove, J. and Schilling, M. 1997. A shift in distribution of humpback whales, Megaptera novaenagliae, in response to prey in the southern Gulf of Maine. Fishery Bulletin, 95, 826-836.

Wenz, G. M. 1962. Acoustic ambient noise in the ocean: spectra and sources, J ournal of the Acoustical Society of America 34, 1936-1956.

White, J. and Esteban, N. 2007. Tanker anchoring impact studies and recommendations. St Eustatius marine Park. 29 pp.

Wright, A. and Kyhn, L.A. 2015. Practical management of cumulative anthropogenic impacts with working marine examples. Conservation Biology, Volume 29, No. 2, 333-340. DOI: 10.1111/cobi. 12425

Wright, A. J. and Walsh, A. 2010. Mind the gap: why neurological plasticity may explain seasonal interruption in humpback whale song. Journal of the Marine Biological Association of the United Kingdom. 90 (8): 1489-1491. doi: 10.1017/s0025315410000913.

Yan, S., Subramanian, S., Tyagi, R., Surampalli, R., and Zhang, T. 2010. Emerging Contaminants of Environmental Concern: Source, Transport, Fate, and Treatment. Pract. Period. Hazard. Toxic Radioact. Waste Manage., 10.1061/(ASCE)HZ.1944-8376.0000015, 2-20. 


\section{J ustification}

Report C097/17

Project Number: 4318100101

The scientific quality of this report has been peer reviewed by a colleague scientist and a member of the Management Team of Wageningen Marine Research.

Approved: $\quad$ Dr. H.V. Winter

Scientific researcher

Signature:

Date:

22-11-2017

Approved:

Dr.ir. T.P. Bult

Signature: 


\section{Annex 1 IUCN Red List status of marine mammals occurring in the WCR}

Source: IUCN (2008). Species names in bold letters indicate those species documented for the Dutch Caribbean (Debrot et al., 2011a).

\begin{tabular}{|c|c|c|c|c|}
\hline Species & Scientific name & IUCN status & IUCN trend & Red List EEZ \\
\hline North Atlantic right whale & Eubalaena glacialis & Endangered & Unknown & \\
\hline blue whale & B. musculus & Endangered & Increasing & \\
\hline fin whale & B. physalus & Endangered A1d & Unknown & \\
\hline sei whale & B. borealis & Endangered & Unknown & \\
\hline Bryde's whale & B. edeni & Data deficient & Unknown & \\
\hline common minke whale & B. acutorostrata & Least concern & stable & \\
\hline humpback whale & Megaptera novaeangliae & Least concern & Increasing & Vuln. \\
\hline sperm whale & Physeter macrocephalus & Vulnerable A1d & Unknown & Vuln. \\
\hline pygmy sperm whale & Kogia breviceps & Data deficient & Unknown & \\
\hline dwarf wperm whale & Kogia simus & Data deficient & Unknown & \\
\hline Cuvier's beaked whale & Ziphius cavirostris & Least concern & Unknown & \\
\hline Blainville's beaked whale & Mesoplodon densirostris & Data deficient & Unknown & \\
\hline Sowerby's beaked whale & Mesoplodon bidens & Data deficient & Unknown & \\
\hline Gervais' beaked whale & Mesoplodon europaeus & Data deficient & Unknown & \\
\hline True's beaked Whale & Mesoplodon mirus & Data deficient & Unknown & \\
\hline killer whale & Orcinus orca & Data deficient & Unknown & \\
\hline $\begin{array}{l}\text { long-finned pilot } \\
\text { short-finned pilot }\end{array}$ & Globicephala melas & Data deficient & Unknown & \\
\hline whale & G. macrorhynchus & Data deficient & Unknown & \\
\hline false killer whale & Pseudorca crassidens & Data deficient & Unknown & \\
\hline pygmy killer whale & Feresa attenuata & Data deficient & Unknown & \\
\hline melon headed whale & Peponocephala electra & Least concern & Unknown & \\
\hline tucuxi & Sotalia fluviatilis & Data deficient & Unknown & \\
\hline guiana dolphin & Sotalia guianensis & Data deficient & Unknown & \\
\hline rough toothed dolphin & Steno bredanensis & Least concern & Unknown & \\
\hline risso's dolphin & Grampus griseus & Least concern & Unknown & \\
\hline \multirow{2}{*}{$\begin{array}{l}\text { bottlenose dolphin } \\
\text { pantropical spotted } \\
\text { dolphin }\end{array}$} & Tursiops truncatus & Least concern & Unknown & \\
\hline & Stenella attenuata & Least concern & Unknown & \\
\hline \multirow{2}{*}{$\begin{array}{l}\text { Atlantic spotted dolphin } \\
\text { spinner dolphin }\end{array}$} & Stenella frontalis & Data deficient & Unknown & \\
\hline & Stenella longirostris & Data deficient & Unknown & \\
\hline clymene dolphin & Stenella clymene & Data deficient & Unknown & \\
\hline \multirow{3}{*}{$\begin{array}{l}\text { striped dolphin } \\
\text { short beaked common } \\
\text { dolphin } \\
\text { long beaked common } \\
\text { dolphin }\end{array}$} & Stenella coeruleoalba & Least concern & Unknown & \\
\hline & Delphinus delphis & Least concern & Unknown & \\
\hline & Delphinus capensis & Data deficient & Unknown & \\
\hline \multirow{2}{*}{$\begin{array}{l}\text { fraser dolphin } \\
\text { boto }\end{array}$} & Lagenodelphis hosei & Least concern & Unknown & \\
\hline & Inia geoffrensis & Data deficient & Unknown & \\
\hline \multirow{3}{*}{$\begin{array}{l}\text { West Indian manatee } \\
\text { Caribbean monk seal } \\
\text { hooded seal }\end{array}$} & Trichechus m. manatus & Vulnerable A3cd & Decreasing & Vuln. \\
\hline & Monachus tropicalis & Extinct & none & Ext. \\
\hline & Cystophora cristata & Vulnerable & Declining & Vuln. \\
\hline
\end{tabular}




\section{Annex 2 Cetacean guide}

Cetacean guide: Short ID sheet whales and dolphins Dutch Caribbean. Source: Scheidat et al. (2015)

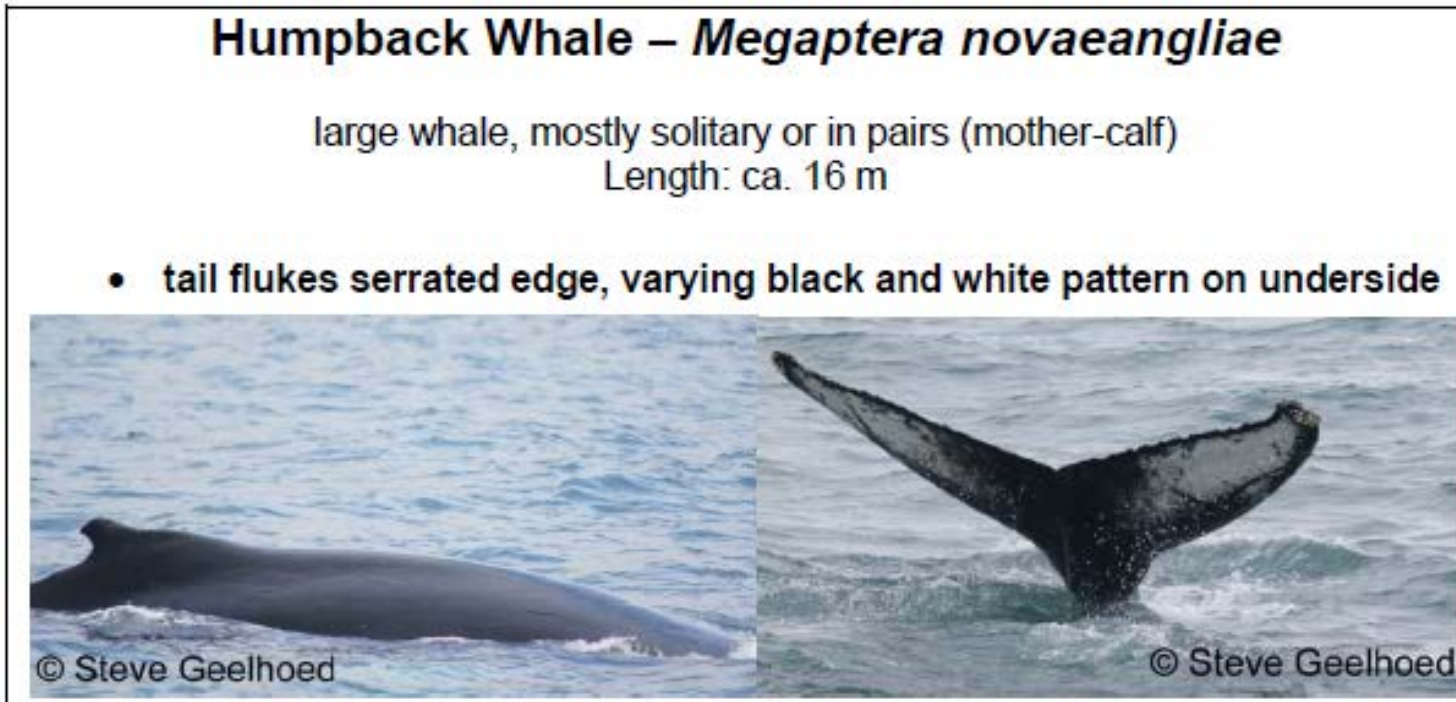

- extremely long flippers (appr. $4 \mathrm{~m}$ )

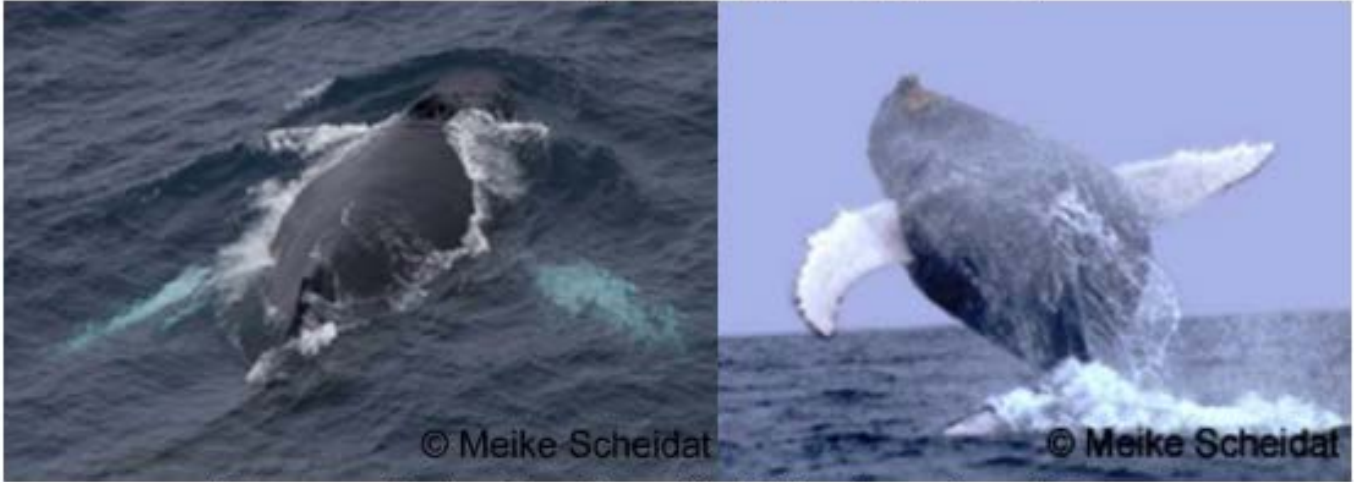

- blow rounded and bushy, still visible when dorsal fin emerges

- small bump before the small dorsal fin

- tubercles on head and lower jaw
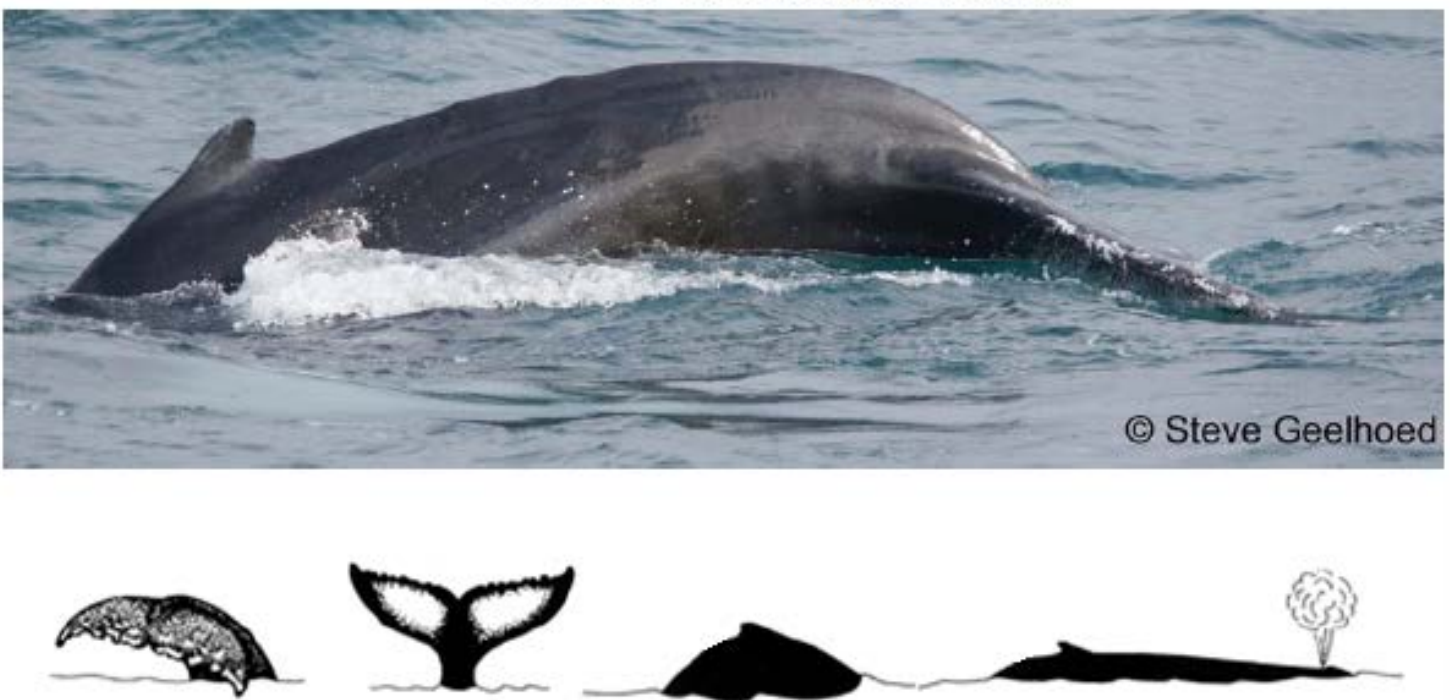


\section{Fin Whale Balaenoptera physalus}

large whale; length : 24m

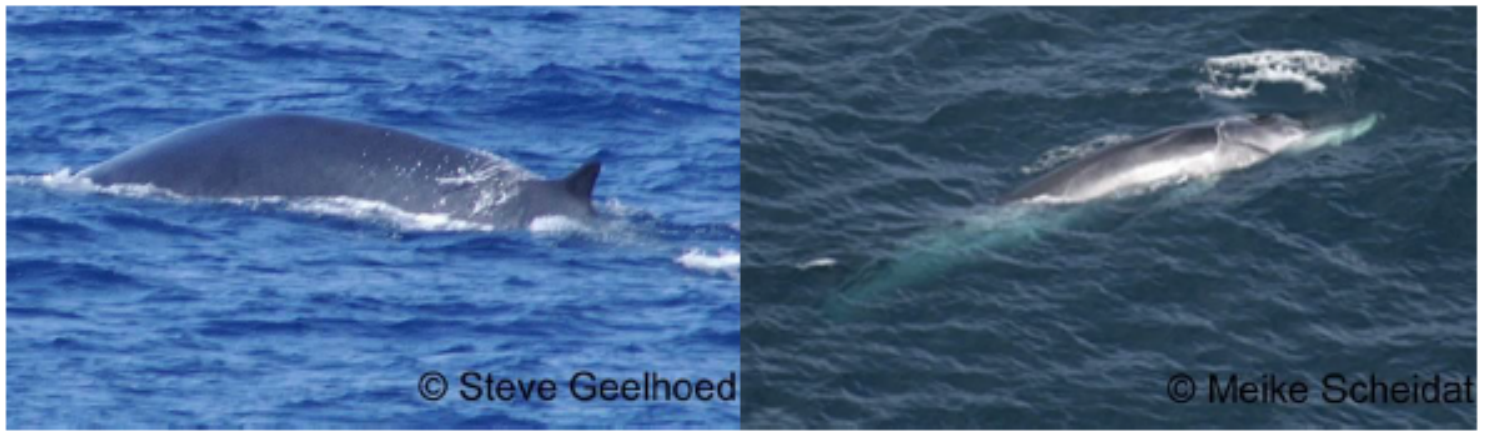

- $\quad$ right lower jaw white, V-shaped pattern (chevron) behind head

- tall, columnar blow, blowhole surface briefly before dorsal fin emerges

- rarely shows tail before diving

- sharp dorsal fin, often pointed or falcate

- coloration: dark grey above, white/cream below

\section{Minke Whale Balaenoptera acutorostrata}

small size whale; length: 9-11m

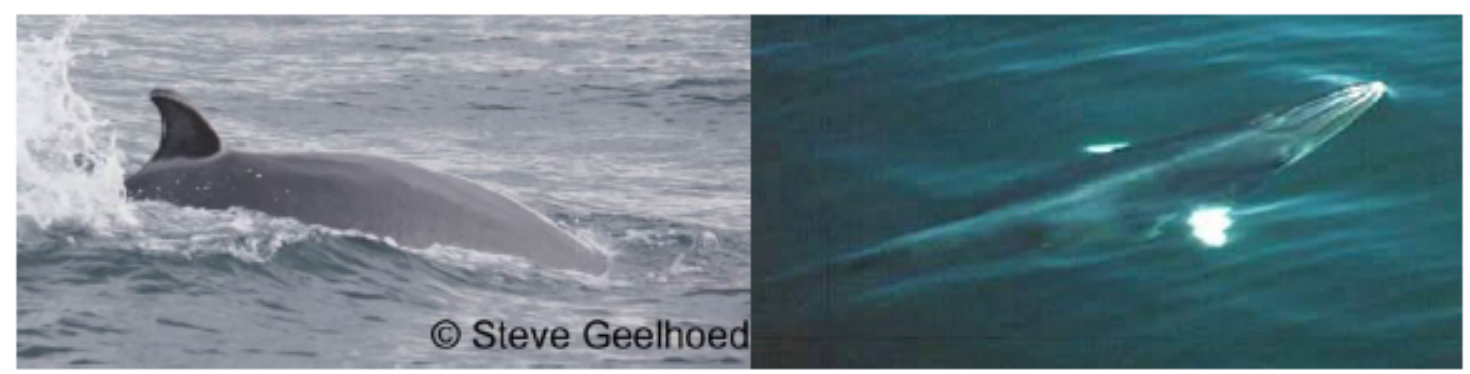

- sharply pointed snout; sharp ridge on the snout

- V shaped head when seen from above

- falcate dorsal fin, appears simultaneously with the blowholes during surfacing

- white band on flippers

- no fluke up when diving, often arches the back

- inconspicuous or no blow

- coloration: black or dark grey above; grey chevron behind head; white underneath 


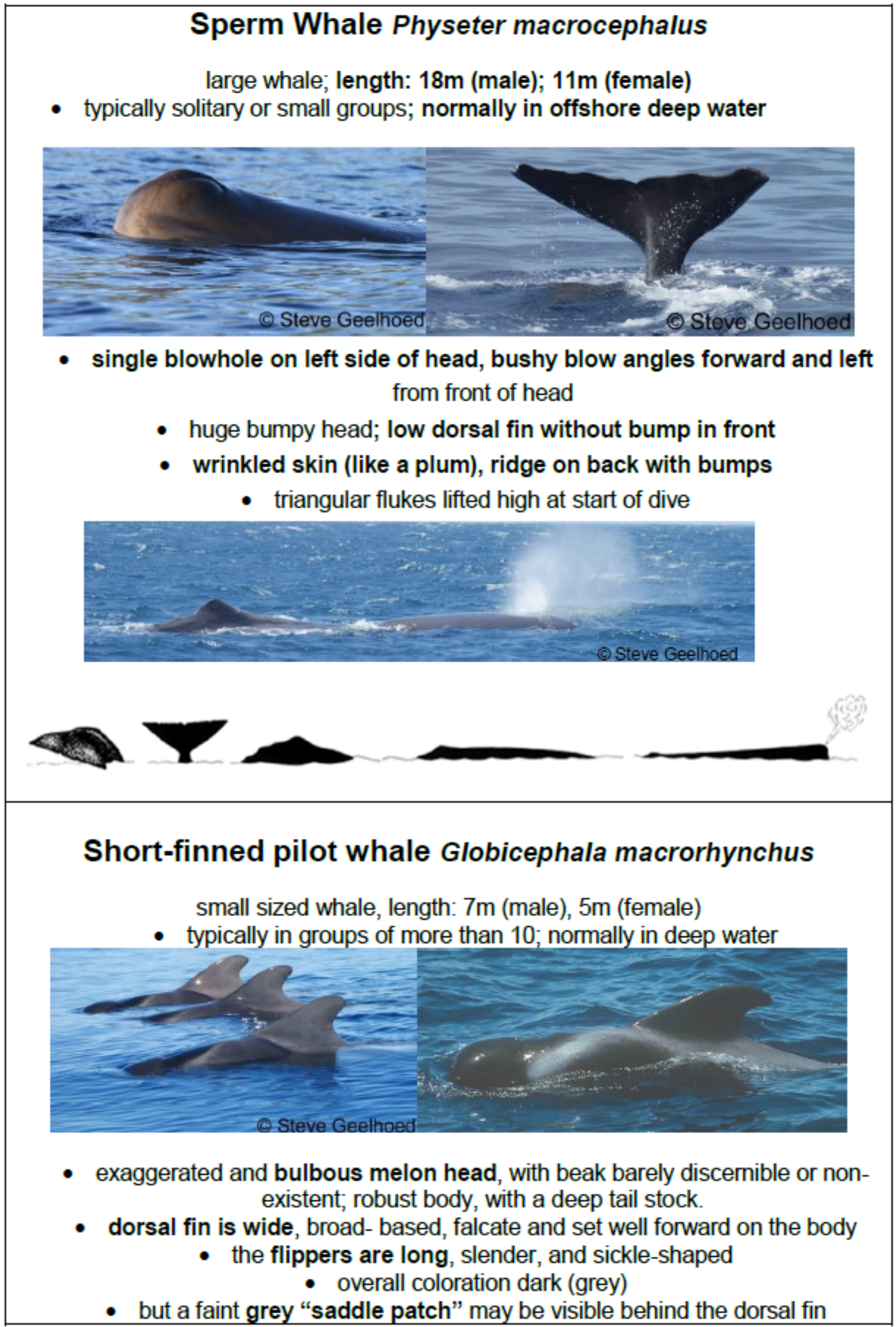




\section{Bottlenose dolphin Tursiops truncatus}

medium-sized to large dolphin, length: 2.5 to $4 \mathrm{~m}$

- typically groups: 10 or more (also bow riding but less often than spinner)

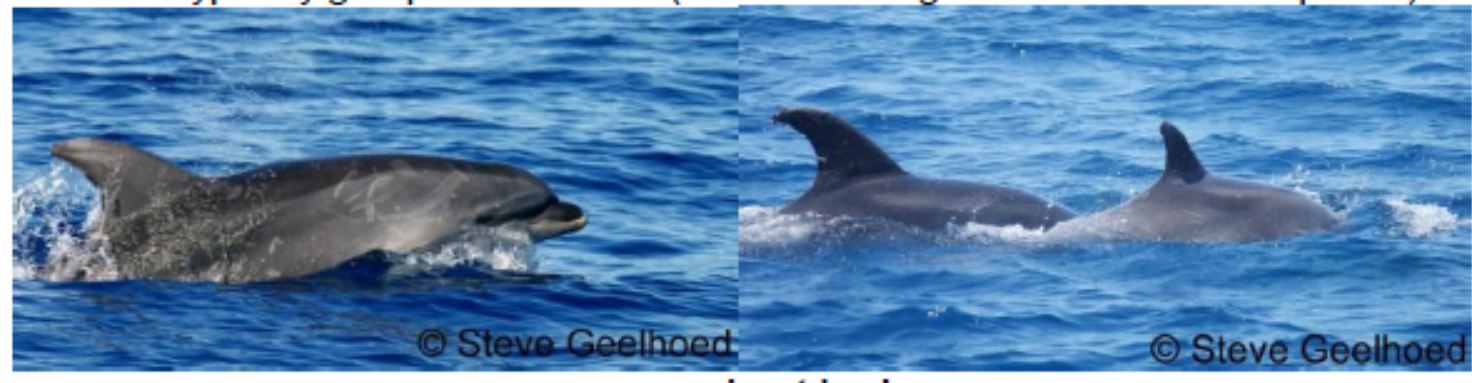

- robust body

- short to medium-length "stubby" beak

- distinct forehead above beak

- large falcate dorsal fin

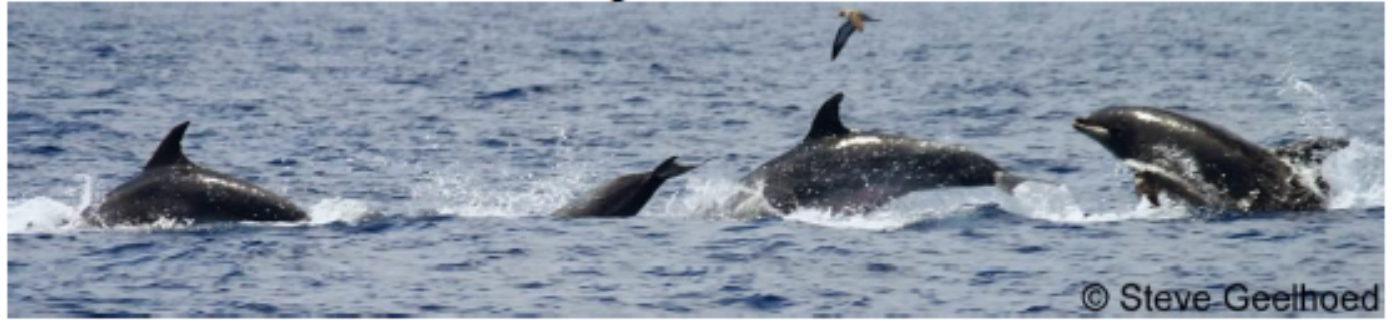

\section{Spinner dolphin Stenella longirostris}

small to medium sized dolphin, length: $1.30 \mathrm{~m}$ to $2.30 \mathrm{~m}$

- typically groups of 10 or more (also bow riding)

- they can be seen spinning high in the air

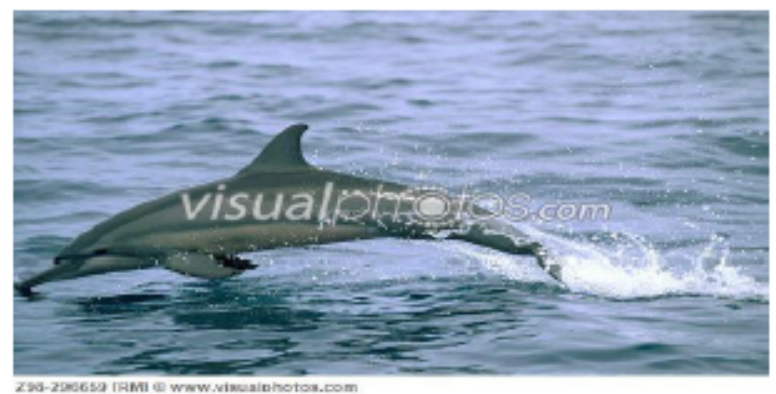

- slender body with an extremely long and thin beak

- on top dark grey cape, light grey on the sides and white on the belly

- a dark band runs from the eye to the flipper, bordered above by a thin light line

- the beak is tipped with black or grey

- the dorsal fin is basically triangular, slightly falcate to erect or canted forward 


\section{Clymene dolphin (Stenella clymene)}

small dolphin, length: 1.70 to $2 \mathrm{~m}$

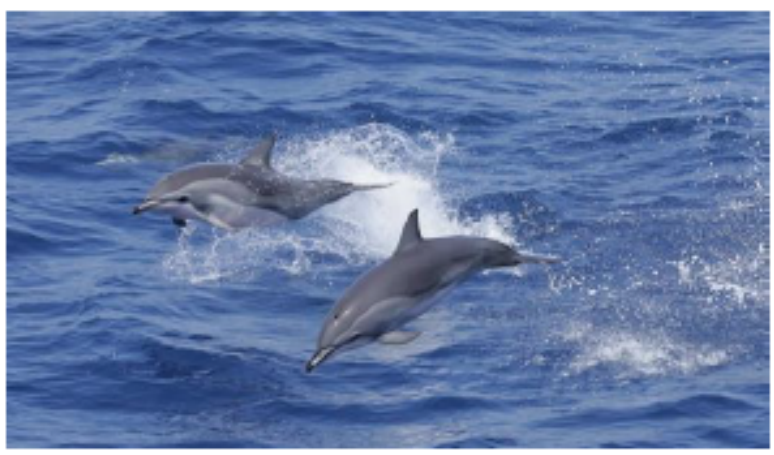

- small but rather stocky and has a moderately long beak.

- dorsal fin is tall and nearly triangular to slightly falcate

- white belly, light grey flanks and dark grey cape

- black "moustache" marking of variable extent at the top of the beak.

- very similar to the spinner dolphin, coloration looks vaguely like a grey Common dolphin

\section{Common dolphin (Delphinus delphis)}

small dolphin, length $1.60 \mathrm{~m}$ to $2 \mathrm{~m}$

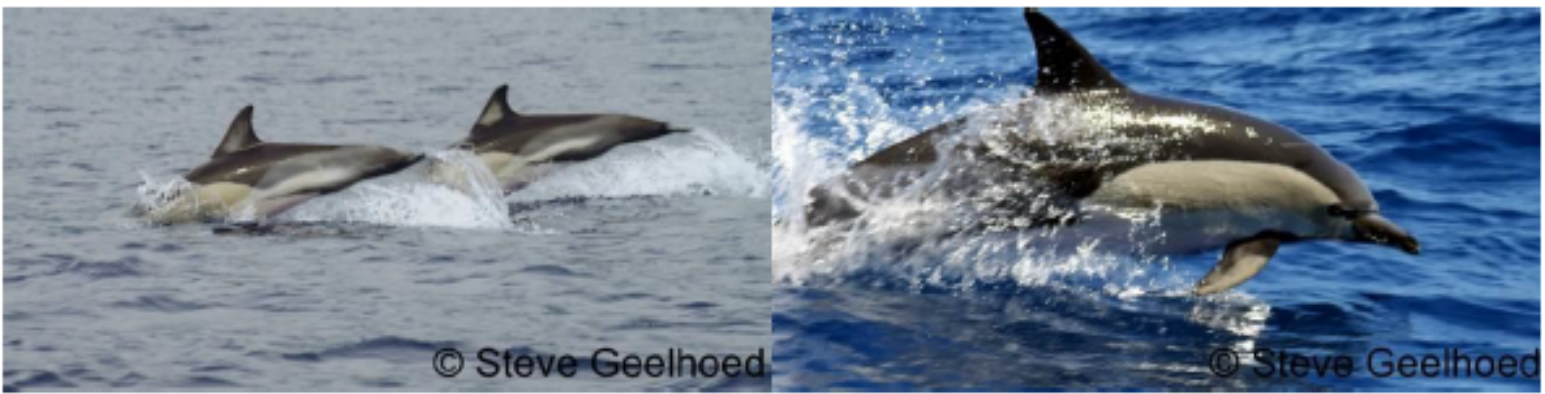

- slender body with a long beak sharply demarcated from the melon

- the dorsal fin is high and moderately curved backwards, often with pale centre

- unique (hourglass) pattern with a pale yellow patch on the side 


\section{Atlantic spotted dolphin (Stenella frontalis)}

small dolphin, length: 1.7 to $2.3 \mathrm{~m}$

- often in groups of animals with different ages

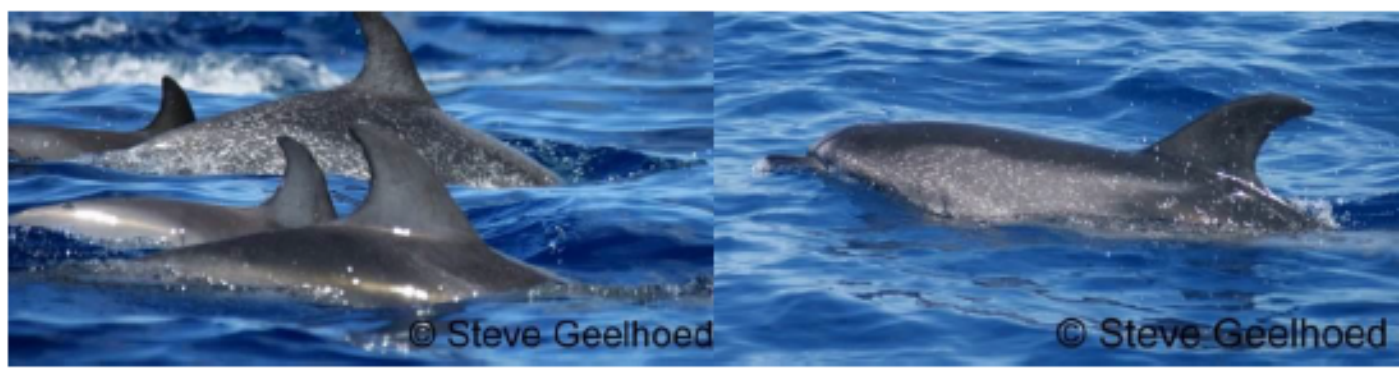

- overall impression of a small (spotted) Bottlenose dolphin

- moderately long, stocky beak, with a distinctive forehead above the beak

- the dorsal fin is tall and falcate and the flippers are curved backwards

- juveniles are unspotted, older individuals acquire spots

- very similar to the other dolphins occurring here

\section{Pantropical spotted dolphin (Stenella attenuata)}

small dolphin, length: 1.6 to $2.6 \mathrm{~m}$

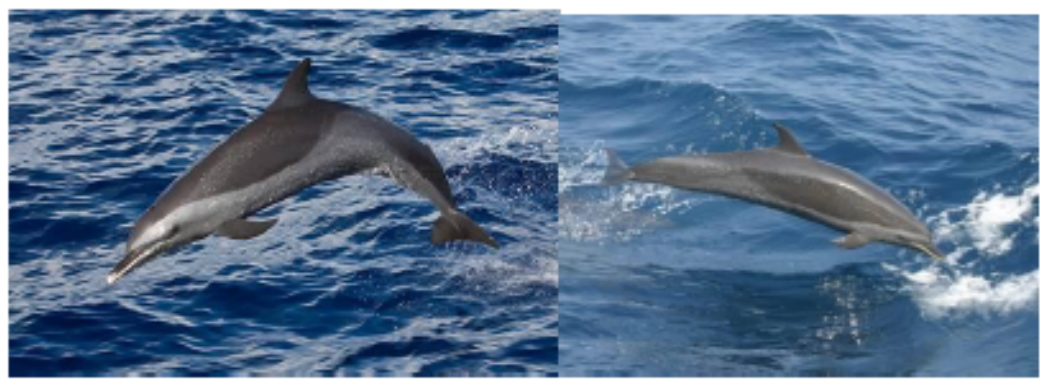

- long beak sharply demarcated from the melon, slender body, strongly backward curved fin and spotted body

- the ventral spots fuse and fade to a medium grey

- tip of the beak is white

- details of coloration and spot intensity vary regionally

- the newborn calf is unspotted, older individuals acquire spots

- very similar to the Atlantic spotted dolphin and the other dolphins occurring here 


\section{Annex 3 Questionnaire}

\section{GOALS}

What should the management goals be for the Yarari Sanctuary marine mammals?

(15 minutes)

Please differentiate potential goals according to importance using the following categories. (Note: it is essential to use as many of the four categories as possible for each question. Only then is will it be possible to actually distinguish differences in priority).

$\mathrm{H}=$ High priority, essential for the Yarari sanctuary

$M=$ Medium priority, important but not essential for the Yarari sanctuary

$\mathrm{L}=$ Low priority, complementary to the Yarari sanctuary

$\mathrm{N}=$ Not really needed for the Yarari sanctuary

Goal a

( ) Manage the Yarari sanctuary to maintain, protect, restore and enhance natural habitats and populations of cetaceans.

\section{Goal b}

( ) Build, maintain, and enhance the operational capability and infrastructure necessary to achieve key Yarari marine mammal conservation goals.

Goal c

( ) Enhance nation-wide public awareness, understanding, and appreciation of marine mammals.

Goal d

( ) Expand and strengthen sanctuary management throughout the Dutch Caribbean.

Goal e

( ) Investigate and enhance the understanding of marine mammals in and around the Yarari reserve.

Goal $f$

( ) Facilitate compatible human use of the Yarari sanctuary.

Goal g

( ) Work with the international and inter-island community to strengthen marine mammal conservation in the Caribbean region. 


\section{OBJ ECTI VES}

What should be the objectives for the different goals for Yarari Sanctuary marine mammals?

Please categorise potential objectives for each goal according to the above categories, H,M.L,N).

(Note: it is essential to use as many of the four categories as possible for each question. Only then is will it be possible to actually distinguish differences in priority).

เ

Goal a: Manage the Yarari Sanctuary to maintain, protect, restore and enhance natural habitats and populations of cetaceans

( ) Prepare sanctuary management plans.

( ) Conduct and maintain routine contingency planning to preserve and restore the integrity of sanctuary ecosystems.

( ) Develop and maintain programs and partnerships for enforcement.

( ) Review and evaluate the Yarari's effectiveness at site, regional, and national levels.

( ) Anticipate, prevent and mitigate threats to resources.

( ) Assess changes affecting Yarari and evolve management strategies accordingly.

Goal b: Build, maintain, and enhance the operational capability and infrastructure necessary to achieve key Yarari marine mammal conservation goals

( ) Cultivate a highly qualified and dedicated staff for Yarari.

( ) Implement a regional management structure to integrate Yarari into region-based marine mammal networks.

( ) Support and expand the volunteer programs for support and awareness.

( ) Maintain, and enhance the facilities, equipment, and other infrastructure required for conducting operations.

Goal c: Enhance nation-wide public awareness, understanding, and appreciation of marine mammals

( ) Provide education opportunities that will reach a diverse national population.

( ) Implement outreach programs to increase awareness of marine mammals and Yarari.

( ) Establish partnerships to supplement the Yarari's education and outreach efforts

Goal d: Build and strengthen Yarari Sanctuary management

( ) Facilitate identification of potential expansion, in coordination with key stakeholders.

( ) Initiate, coordinate and participate in ecosystem-based and network initiatives.

( ) Develop and maintain interagency partnerships and collaborations, particularly with other national and international protected area and resource managers

Goal e: Investigate and enhance the understanding of marine mammals in and around the Yarari Sanctuary

( ) Expand observing systems and monitoring efforts within and near Yarari to fill important gaps in the knowledge of marine mammals and potential threats.

( ) Support directed research activities that support management decision-making.

( ) Develop audio visual products for awareness

Goal f: Facilitate compatible human use of the Yarari Sanctuary reserve

( ) Work closely with partners to assess and manage human use of sanctuary resources.

( ) Create, operate, and support community-based sanctuary advisory councils.

( ) Consult and coordinate with agencies and partners conducting activities in or near Yarari.

( ) Use other tools such as policy development, permitting, and regulatory review and improvement to help guide human use of sanctuary resources.

( ) Create and support programs and strategies to work with island inhabitants.

Goal g: Work with the international and inter-island community to strengthen marine mammal conservation in the Caribbean region

( ) Develop multilateral program relationships to interact with international partners to improve Yarari management capacity. 
( ) Investigate the use of international legal conventions and other instruments to help protect marine mammals.

( ) Cooperate with global research initiatives to improve the overall knowledge of marine mammals.

( ) Make Yarari education and awareness programs accessible through international efforts. 
Wageningen Marine Research

T +31 (0)317480900

E: marine-research@wur.nl

www.wur.eu/marine-research

Visitors' address

- Ankerpark 27, 1781 AG Den Helder

- Korringaweg 5, 4401 NT Yerseke

- Haringkade 1, 1976 CP IJ muiden
Wageningen Marine Research is the Netherlands research institute established to provide the scientific support that is essential for developing policies and innovation in respect of the marine environment, fishery activities, aquaculture and the maritime sector.

\section{Wageningen University \& Research:}

is specialised in the domain of healthy food and living environment.

\section{The Wageningen Marine Research vision}

'To explore the potential of marine nature to improve the quality of life'

\section{The Wageningen Marine Research mission}

- To conduct research with the aim of acquiring knowledge and offering advice on the sustainable management and use of marine and coastal areas.

- Wageningen Marine Research is an independent, leading scientific research institute

Wageningen Marine Research is part of the international knowledge organisation Wageningen UR (University \& Research centre). Within Wageningen UR, nine specialised research institutes of the Stichting Wageningen Research Foundation have joined forces with Wageningen University to help answer the most important questions in the domain of healthy food and living environment. 